\title{
Forgive me all my sins: \\ How penalties imposed on banks travel through markets
}

\author{
Christian Flore ${ }^{\mathrm{a}, *}$, Hans Degryse ${ }^{\mathrm{b}}$, Sascha Kolaric ${ }^{\mathrm{a}}$, Dirk Schiereck ${ }^{\mathrm{a}}$ \\ ${ }^{a}$ Department of Business Administration, Economics and Law, Technische Universität Darmstadt, \\ Hochschulstr. 1, 64289 Darmstadt, Germany \\ ${ }^{b} \mathrm{KU}$ Leuven and CEPR, Naamsestraat 69, 3000 Leuven, Belgium
}

${ }^{*}$ Corresponding author, Email: christian.flore@tu-darmstadt.de, Tel.: +496151 1624295. 
Forgive me all my sins:

How penalties imposed on banks travel through markets

\begin{abstract}
From 2005 to 2015, the 25 largest global financial institutions paid combined more than $\$ 285$ billion in legal penalties. We examine the reaction of banks' stocks, bonds, and credit default swaps to the announcements of monetary penalties. We observe a reduced default risk and lower financing costs, as well an increase in the stock market valuation, suggesting that banks benefit from settling lawsuits. The positive reaction is likely driven by the resolution of uncertainty surrounding these proceedings. While the sued bank's systemic risk increases in the size of the relative monetary penalty, we also document positive spillover effects to other banks facing pending lawsuits with the same plaintiff, demonstrating the systemic effect of law enforcement against banks. Furthermore, banks appear to correctly anticipate penalties, as they are cash flow-effective but not income-effective in the year they are announced.

Keywords: banks, lawsuits, settlements, legal fines, financial markets JEL: G14, G21, K10, K41, K42
\end{abstract}

\title{
1. Introduction
}

Financial institutions were subject to large legal settlements during the recent past. From 2005 to 2015, the 25 largest financial institutions paid combined more than $\$ 285$ billion in penalties, which corresponds to approximately 20\% of their 2004 year-end market value. Prominent settlement cases include, among others, Bank of America in August 2014 for almost $\$ 17$ billion with the US Department of Justice (DOJ) for financial fraud leading up to and during the global financial crisis, BNP Paribas in June 2014 for approximately $\$ 9$ billion with multiple US authorities for violations of US sanctions, and UBS's \$19 billion agreement with the New York Justice Department for the misrepresentation of securities in 
August 2008.

Banks typically resolve their legal disputes through settlements. ${ }^{1}$ The number of settlements as well as the involved penalty amounts imposed on banks rose steadily during the period from 2005 to 2015 (see Figure I). From 2005 to 2010, with the exception of 2008, these institutions paid between 689 million and 7 billion US dollars annually. This number increased markedly between 2011 and 2014 to approximately 42 billion US dollars annually, underscoring the relevance and magnitude of these legal proceedings. The vast majority of settlements involved US authorities. However, penalties and settlements with European authorities, particularly with the UK Financial Conduct Authority (FCA), also increased in recent years. This led European authorities to raise concerns that misconduct related penalties may become a source of systemic risk for the banking sector (European Systemic Risk Board, 2015).

\section{[Place Figure [1] approximately here]}

In this paper, we answer the question on how these settlements affect banks along multiple dimensions by considering a bank's valuation through the equity market, its external financing costs through the bond market, and its credit default risk as reflected in the creditdefault swap (CDS) market. Additionally, we document how the resolution announcements travel through these three different markets, and investigate the effect resolution announcements have on banks' financial statements. We also study whether resolution announcements generate spillovers to the financial system. We do so by investigating the impact of resolution announcements on the stock prices of comparable banks facing similar lawsuits and consider the effect of penalty size on banks' systemic risk. In doing so we comprehensively investigate the effects of financial penalties on banks. Prior studies do not account for potential spillover effects to comparable financial institutions facing similar penalties or the effect on the sued

\footnotetext{
${ }^{1}$ The vast majority of cases, lawsuits or enforcement processes against corporate defendants are resolved through settlements. In the following, for ease of formulation, we will therefore generally use the term settlement even though it may also encompasses a few non-settlement resolutions.
} 
bank's systemic risk and do not investigate the effect on the bond and CDS market (e.g., Gande and Lewis, 2009; Karpoff, Lee, and Martin, 2017; Armour, Mayer, and Polo, 2017; Köster and Pelster, 2017). Taking into account the effect of legal proceedings on a bank's default risk, systemic spillover effects, as well as systemic risk is of particular importance in the context of the banking sector given its central role in the transmission of shocks to the real economy.

To investigate our research questions, we hand-collected data on more than 400 legal settlements that involved at least one of the 25 largest financial institutions between 2005 and $2015 \mathrm{2}^{2}$ For every event we carefully control for other stock price relevant events surrounding the settlement announcement to ensure that the measured effect is due to the settlement announcement itself, resulting in a final sample of 251 events..$^{3}$

Of the 25 largest financial institutions, 23 had at least one settlement within our investigation period. Nine of these 23 institutions are from the US, the remaining 14 from Europe. The European banks include five from the United Kingdom, three from France, two from Germany and Switzerland, and one from the Netherlands and Spain. All financial institutions in our sample have global operations and are bound by the laws of the respective jurisdictions they are operating in and may therefore be sanctioned in case of non-compliance with respective local laws and regulations. We include in our database all enforcement actions against these banks from US and European plaintiffs and regulators. Figure III shows the penalty amounts assigned and received by US and European law enforcers and banks. It is apparent that the US is distinctly more active than Europe in sanctioning domestic as well as foreign banks. $\$ 271$ billion in penalties are assigned by US law enforcers while only $\$ 14$ billion by European law enforcers, which translates into a share of $95 \%$ in terms of penalties.

\footnotetext{
${ }^{2}$ This is determined by the market capitalization of the 25 largest European and US banks in 2004 and 2015, respectively. A bank is included into the database if it belongs to that group in either one of those years.

${ }^{3}$ To capture only meaningful events, we focus on penalties in excess of $\$ 5$ million. We use this materiality threshold as it is impossible to control for confounding events for small penalties. A penalty of $\$ 500,000$, for example, would be $0,001 \%$ of a $\$ 50$ billion market capitalization. The effect of this event will very likely be negligible compared to most information and developments influencing a bank's valuation on any given day.
} 
In terms of the number of cases the difference is still stark but somewhat less pronounced with $83 \%$ of all enforcement actions in our sample being enforced by US plaintiffs and $17 \%$ by European ones. The US is not only the most important law enforcer for US banks but also for European banks. The latter received $\$ 60$ billion of their total of $\$ 71$ billion, or $85 \%$, in penalties from US law enforcers. This shows the relevance of enforcement actions against foreign defendants, particularly for foreign banks operating in the US.

[Place Figure II approximately here]

Our study contributes to the literature on valuation effects of enforcement actions against banks in general, and for settlements in particular, in multiple ways. First, we go beyond the equity market analysis and also consider debt and credit default risk. This is of particular interest for financial institutions given their central role in the economy. Prior studies (e.g., Armour et al., 2017; Bhagat, Brickley, and Coles, 1994; Flore, Kolaric, and Schiereck, 2017; Karpoff, Lee, and Martin, 2008; Gande and Lewis, 2009) do not consider debt or credit markets and frequently use cross-industry samples, therefore only allowing for limited conclusions with respect to financial institutions. Second, we investigate how financial penalties disseminate from the equity to debt and credit-default swap markets, thereby showing the interrelationship between these markets. To the best of our knowledge, this is the first study that documents the effect of financial penalties associated with legal proceedings for these markets and thereby provides first evidence on the speed of information dissemination of settlement announcements through equity, debt, and credit-default swap markets. Third, we investigate the spillover effects of settlements to comparable large financial institutions. This is to learn whether settlements generate negative contagion effects or provide new information reducing uncertainty associated with such settlements. We additionally study whether the size of the settlements impacts the sued banks' contribution to systemic risk. Finally, we investigate the effect of penalties on bank's financial statements and subsequent lending behavior. This allows for conclusions on how penalties affect banks' liquidity, profitability, 
but also lending activities towards the real sector.

Our results show significant positive valuation effects of $0.30 \%, 2.36 \mathrm{bps}$, and $-0.71 \mathrm{bps}$ for the stock, bond, and CDS market, respectively. This suggests that the settlement of law suits is generally viewed as a positive event by capital market participants. At the time of the settlement, negative information has already been priced in; the actual settlement reduces a bank's default risk, its financing costs and increases its stock market valuation. Larger settlements are associated with more pronounced stock market valuation effects, consistent with a greater reduction in uncertainty. Further substantiating this result, we document that banks with greater stock return volatility prior to the settlement enjoy larger announcement effects in stock markets. The interactions between stock, bond, and CDS markets around resolution announcements are examined using a simultaneous regression framework. The results show that the settlement affects stock and CDS markets directly on the announcement day and that these markets transmit the effect to the bond market with a one day lag.

We also find that the resolution of legal enforcement actions has positive spillover effects towards comparable financial institutions with pending lawsuits from the same plaintiff. At the same time, employing three different measures for the sued bank's contribution to systemic risk, we find weak evidence that a bank's contribution to systemic risk increases the larger the size of the relative monetary penalty. This evidence, albeit somewhat mixed, underscores the systemic relevance of law enforcement actions against banks, as pointed out by the European supervisory authorities (European Systemic Risk Board, 2015).

Finally, we evaluate whether a bank's annually paid monetary penalties have an impact on its cash flow, net income, tier 1 ratio, and lending. We document that monetary penalties reduce annual cash flows nearly one-to-one in the announcement year, reflecting the cash flow-effectiveness of these settlements. In contrast, banks' net income is unaffected by the announced penalties, suggesting that monetary penalties are not income-effective in the year they are announced. Yet, as they are cash flow-effective, this provides tentative evidence 
that banks appropriately account for impending penalties prior to the fiscal year of the resolution announcement. The settlement announcement effect should therefore be driven by the resolution of uncertainty. Using bank-level data, we further document that banks' tier 1 ratio and lending growth are not affected by the size of the financial penalties.

The remainder of the paper is structured as follows. Section 2 gives the general background for legal enforcement actions against banks while Section 3 reviews selected literature and develops the main hypotheses. Section 4 gives an overview of the construction of the database and offers descriptive statistics of the sample. Section 5 presents the empirical analyses for the affected banks. Section 6 considers the dissemination of penalties through financial markets. Section 7 offers insights into the effect of fines and settlements on the banks' financial statements, and Section 8 investigates the interdependence of financial penalties and systemic risk. Section 9 concludes.

\section{Background}

Financial institutions face multiple legal and regulatory enforcement threats that potentially lead to large penalties. Independent of the plaintiff or prosecutor, corporations in general have a strong preference for settling disputes in contrast to going to trial. Settlements significantly reduce the costs associated with lengthy court trials and are therefore an attractive option to quickly end a dispute. A settlement is usually possible at every stage of a lawsuit and particularly common in the US, where it is also frequently used to resolve criminal prosecutions (e.g., Flore et al., 2017).

\section{[Place Figure III approximately here]}

Figure III provides a categorization of legal enforcement threats to banks. A bank may face regulatory actions by public authorities or civil lawsuits by private parties. Public authorities regulate financial institutions by various means. In some cases the authorities have the power to single-handedly impose fines following a bank's failure to comply with 
regulations. Unless the fine gets appealed there is no court involvement. These cases are labeled as regulatory fines for the purpose of this study. A regulatory fine settlement implies that the investigated bank cooperated during the regulator's investigation and agreed to the imposed sanctions. This cooperation is usually mentioned in the settlement announcement. Regulatory fine orders, in contrast, describe the case where a bank does not agree with the sanctions and may also consider to appeal them. In addition to autonomously imposed regulatory fines, a public authority may also bring a civil lawsuit against a bank, which is likely to be concluded through a settlement. We consider these lawsuits as public lawsuits and settlements are labeled as public settlements. This is in contrast to public judgments, which end with a disputed court judgment ${ }^{4}$ The difference between regulatory fines and public lawsuits can be best explained by using the US Securities and Exchange Commission's (SEC) and the UK's FCA enforcement processes. Although both processes generally result in settlements, the FCA directly imposes regulatory fines, which can later be appealed. The SEC, on the other hand, files and settles civil lawsuits and thereby indirectly imposes penalties. This has important consequences for the first announcement of legal actions. Unless otherwise decided by the investigated party, the FCA's process generally only becomes public when the regulatory fine is announced, while in case of the SEC the process generally becomes public knowledge before the settlement is announced.

A particularity of law enforcement in the US is that corporations are also frequently criminally prosecuted. Firms are potentially criminally liable for crimes committed by their employees acting within the scope of their employment with an intend to benefit the firm Arlen, 2011). Criminal cases are investigated by the responsible enforcement agencies (e.g., the Federal Bureau of Investigations (FBI)) and are prosecuted by the DOJ, which alone is authorized to undertake prosecution under criminal federal law. Corporate crime is thereby

\footnotetext{
${ }^{4}$ Most settlements with public authorities are eventually being put into a consent decree or consent judgment by a federal or state court. Thereby the settlement terms are enforceable by the court and breaches qualify as obstruction of justice, alleviating the enforcement of settlement terms. These judgments are not considered public judgments for the purpose of this study.
} 
practically exclusively treated on the federal level. There are three ways to settle a criminal prosecution: Plea agreements (PAs), deferred prosecution agreements (DPAs), and nonprosecution agreements (NPAs). A plea bargain or plea agreement is an agreement between prosecutor and defendant. A key component is the admission of guilt and the defendant's final conviction. Charges need to be filed and the agreement is dependent on a final court approval. In contrast to PAs, pretrial diversions, such as DPAs and NPAs, do not require the admission of guilt or a conviction. By avoiding conviction a company may deter costly collateral consequences like debarment or exclusion from government contracts. On the other hand, DPAs and NPAs, on average, include more provisions regarding compliance programs or corporate monitors (Alexander and Cohen, 2015).

Figure III also shows that private lawsuits present another judicial threat to banks. Single-plaintiff lawsuits are mostly brought by other firms (interfirm lawsuits) and in exceptional cases by individuals (individual lawsuits). These lawsuits are likewise frequently settled. The majority of private lawsuits are, however, class actions. In this instance various single-plaintiffs form a group of plaintiffs, which is represented by a member of that group. This member sues the financial institution as a representative of the entire group. Like criminal prosecution of corporations this is rarely practiced outside the US judicial system.

The majority of private and public enforcement actions against banks takes place in the US. Europe, in contrast, has far fewer cases and generally a system that does not rely as much on assigning penalties to regulate financial institutions. The UK, however, is somewhat different from other European countries. It is distinctly less active in comparison to the US, but its FCA is by far the most active European regulator. Table 1 provides additional information concerning the major law enforcers as well as private plaintiffs. 5 Public

\footnotetext{
${ }^{5}$ We define all plaintiffs and regulators as major law enforcers that have more than 10 cases in our investigation period or those who have less than 10 cases but considerably high total monetary penalties assigned. As Switzerland is a non-European Union country, we also included the Swiss Financial Market Supervisory Authority (FINMA) in Table I to provide a better overview of European regulators. The Table is skewed towards US plaintiffs and regulators which is due to them being responsible for the majority of enforcement actions against banks in our sample.
} 
enforcement is conducted by multiple regulatory authorities that supervise different parts of the financial system. They regulate and sanction banks that do business within the scope of their jurisdiction irrespective of the location of those banks' head quarters. Speaking to this fact, $33 \%$ of all US enforcement actions in our database have been against European banks and $18 \%$ of European enforcement actions have been against US banks. More strikingly, for European banks $66 \%$ of cases in our database and $85 \%$ of penalties assigned against them stem from US enforcement actions.

The activities of the federal and state-level Justice Departments, which play a major role in banking law enforcement, can be summarized under general law enforcement. The regulatory regime can be generally divided into two types of regulators. Financial institution regulators, which regulate particular types of institutions for risky behavior or conflicts of interest, and financial market regulators, which promulgate rules for certain financial transactions no matter what kind of firm or financial institution engages in them. These regulatory activities are not mutually exclusive (Jickling and Murphy, 2010). The most important financial institution regulators are the Office of the Comptroller of the Currency (OCC) and the Federal Reserve (Fed), which have the responsibility to enforce safety and soundness regulation over federally chartered banks and members of the Federal Reserve System, respectively. The major financial market regulators are the SEC and the Commodity Futures Trading Commission (CFTC), which are tasked with regulating securities markets and the futures and options markets, respectively. With respect to private plaintiffs the three major plaintiff groups are investors, consumers, and shareholders. All three groups often bring class action lawsuits, while institutional investors frequently also bring single-plaintiff lawsuits.

Besides US regulators, national agencies in Europe as well as organs of the European Union also initiate enforcement actions against banks. The majority of those are by the FCA in the United Kingdom. Other national regulators in Europe are involved in comparatively few cases only.

[Place Table I] approximately here] 


\section{Related literature and hypotheses development}

\subsection{Selected literature}

Research on the equity market reaction to the announcements and settlements of fines and penalties is more developed for non-financial firms than for banks. In the context of banks, previous literature mainly investigates regulatory enforcement actions which may lead to a regulatory fine but also frequently to non-monetary restrictions. For the purpose of our paper, these regulatory enforcement actions are only included if they lead to a regulatory fine ${ }^{6}$ In addition to these regulatory fines, our database also contains all other legal actions against banks that lead to a financial penalty, e.g., civil lawsuits or criminal prosecutions by the government, lawsuits by public agencies, lawsuits by other firms, lawsuits by individuals, or class actions (see Figure III). Particularly in terms of direct financial penalties, formal regulatory enforcement actions play a relatively smaller role while other types of law enforcement actions are more important.7

Prior studies on non-financial firms point to more positive reactions for lawsuit resolutions than for lawsuit filing announcements, which generally result in negative equity market reactions (e.g., Karpoff and Lott, 1993; Bhagat et al., 1994; Bizjak and Coles, 1995; Gande and Lewis, 2009; Deng, Willis, and Xu, 2014; Karpoff et al., 2017). Karpoff and Lott (1993) examine the reputational penalties on firms for committing criminal fraud and document significant negative returns of approximately $-1.9 \%$ upon the announcement of a lawsuit filing. They, however, find no significant stock market reaction to settlement announcements. Bhagat et al. (1994), who conducted the first comprehensive analysis of stock market reactions to civil interfirm litigation, likewise observe a significant negative valuation effect of

\footnotetext{
${ }^{6}$ Public authorities regulate financial institutions by various means. In some cases the authorities have the possibility to single-handedly impose fines following a bank's failure to comply with regulations. Unless the fine gets appealed there is no court involvement. These cases are labeled as regulatory fines for the purpose of this study (see Section 2 for a more detailed discussion).

${ }^{7}$ In our database, regulatory enforcement actions account for 132 cases of our total of 409 (32\%). More importantly, these regulatory enforcement actions account for total fines of 36 billion US dollars, which corresponds to only $13 \%$ of the 285 billion US dollars total in our database (see Table II and Table A.I of the Online Appendix).
} 
approximately $-1.0 \%$ of a defendant's share price when a lawsuit filing is announced. Lawsuits settlements, on the other hand, result in significant positive shareholder wealth effect of about 1.6\%. Bhagat et al. (1994) argue that these wealth gains reflect a reduction in expected legal fees or other costs associated with the proceedings as well as information that the plaintiff's case was relatively weak. In a later study, Bhagat, Bizjak, and Coles (1998) again confirm these results and document a negative stock return for the defendant for filings and an insignificant gain for settlements. Flore et al. (2017) examine the shareholder valuation effects of criminal prosecution settlements and find significant positive short-term settlement returns of $0.56 \%$. This positive reaction is attributed to the resolution of uncertainty. Other studies, however, observe negative valuation effects upon lawsuit settlements. Karpoff, Lott, and Wehrly (2005) investigate the reputational penalties of environmental violations and find that settlement announcements lead to weakly significant and negative stock returns of $-0.4 \%$. Lawsuits filings are again associated with significantly negative returns of approximately $-1.6 \%$. The smaller wealth losses for settlement announcements are explained by the arrival of new negative information regarding the lawsuit, which overlap with the positive effect of reduced uncertainty. In a later study, Karpoff et al. (2008) find highly significant negative wealth effects for class action filings and settlements. Several other studies examine stockholder reactions to lawsuit filings or allegations and consistently observe negative returns following lawsuit filings (e.g., Bizjak and Coles, 1995; Gande and Lewis, 2009; Deng et al., 2014; Karpoff et al., 2017).

For banks, studies on the effect of legal enforcement actions can roughly be divided into three different areas of research, all of which are mainly focused on the US. The first area focuses on the equity market reaction to formal investigation announcements (e.g., Brous and Leggett, 1996; Slovin, Sushka, and Polonchek, 1999; Jordan, Peek, and Rosengren, 2000; Pereira, Malafronte, Sorwar, and Nurullah, 2019). The second one looks at the effect these legal announcements have on a bank's risk profile (e.g., Delis, Staikouras, and Tsoumas, 2017), while the third and most recent studies look at the effects that enforcement actions 
have on bank borrowers and loan terms (e.g., Roman, 2020; Delis, Iosifidi, Kokas, Xefteris, and Ongena, 2020).8

The formal announcement of enforcement actions by US authorities leads to negative equity market reactions for the affected banks (Brous and Leggett, 1996; Slovin et al., 1999; Pereira et al., 2019). The severity of the sanction imposed by the enforcement action is one of the drivers determining this negative reaction, with more severe sanctions, such as cease and desist orders, leading to more pronounced negative reactions than civil monetary penalties and formal agreements (Pereira et al., 2019). These penalties, however, do not lead to negative contagion effects, but rather rival banks stand to gain due the anticipated negative reputational repercussions for the sanctioned bank (Slovin et al., 1999).

Enforcement actions against banks in the US also appear to have a positive effect on a bank's risk profile. Delis et al. (2017) document that enforcement actions decrease the risk-taking incentives of the penalized bank, as particularly risk-weighted assets are being decreased by shrinking a bank's portfolio. Additionally, the non-performing loan ratio goes down. However, enforcement actions also lead to a higher return volatility for the affected bank, implying an increased insolvency risk. Roman (2020) shows that the announcement of enforcement action against a bank in the US leads to negative short-term shareholder wealth effects for relationship borrowers of the penalized bank, while non-relationship borrows show no discernible equity market reaction. In addition, the affected banks improve their credit terms and credit availability for large business, while they decrease them for small businesses. Furthermore, following enforcement actions, the affected banks tend to change their syndicated loan structure when they are the lead arranger (Delis et al., 2020). Delis et al. (2020)

\footnotetext{
${ }^{8}$ Formal enforcement actions in the US mainly consist of cease and desist orders and formal agreements and civil monetary penalties. Cease and desist orders indicate concerns by the regulator that the bank in question has a safety and soundness issue, which may ultimately result in that bank's failure. Formal agreements are weaker than cease and desist orders and are negotiated between the bank and the supervisory agency and include actions to remediate the concerns brought by the regulator. Civil penalties are imposed for failure to comply with certain laws and regulations. The focus of our study is on large legal settlements due to misconduct by banks and we therefore, unlike the other studies on the effect of enforcement actions on banks, do not focus on cease and desist orders or formal written agreements.
} 
document that punished lead arrangers increase their loan portion while simultaneously increasing the number of financial and general covenants. This likely reflects an increased monitoring effort and serves as signaling to other lenders to entice them participate in the syndicate.

The study most closely related to ours is by Armour et al. (2017), which focuses on the enforcement action of the UK's financial and securities regulators and its impact on the stock price of the sanctioned firms. They find significant reputational losses, but these losses are confined to misconduct that harms parties trading with the firm. The amount of the reputational loss appears to be uncorrelated to the actual penalty imposed. Armour et al. (2017) limit their investigation to regulatory actions by the Financial Services Authority (FSA) which differs from other enforcement actions $9^{9}$ The FSA directly imposes regulatory fines, which can later be appealed. In doing so, the FSA's process generally only becomes public knowledge when the regulatory fine is announced. The valuation effect then is a compound effect of the first announcement of legal proceedings and its conclusion.

\subsection{Hypotheses development}

Based on the existing literature, we develop three different sets of hypotheses. The first set relates to the equity, bond, and CDS market reaction to settlement announcements. While monetary penalties impose large direct costs on the affected bank, the resolution of legal proceedings reduces operational and legal uncertainty and may therefore be perceived as positive information by investors, also reducing a bank's default risk. The assumption that the removal of uncertainty with respect to legal proceedings leads to positive short-term market reactions can be more formally set within the uncertain information hypothesis framework developed by Brown, Harlow, and Tinic (1988).10 In the setting of this study, investors

\footnotetext{
${ }^{9}$ The FSA was the main financial regulator of the UK prior to the formation of its successor, the FCA. Section 2 contains a more detailed discussion of the particularities of the FSA's enforcement actions.

${ }^{10}$ The uncertain information hypothesis by Brown et al. (1988) assumes that (i) investors are rational and risk averse, (ii) the stock market processes information quickly, and (iii) new major information can immediately be categorized as either good or bad but the full extent of its impact on stock prices is initially uncertain. Consequently, investors will anticipate a conditional probability distribution of returns upon
} 
should react negatively to the unanticipated bad news of legal enforcement actions and set the stock price below its expected value given the available uncertain information about the investigation 11 With the arrival of new, uncertainty reducing information, investors will adapt their valuation. The announcement of a settlement, in this context, resolves a major part of uncertainty, which should lead to positive valuation effects. Therefore, if the removal of uncertainty dominates, we expect to observe a positive effect in the equity and debt market, as well as a lower default risk. Furthermore, if reduced uncertainty is the main driver of the observed valuation effects, we expect to see a positive dependence on the penalty size, as larger settlement amounts are associated with higher levels of uncertainty before the settlement. We therefore hypothesize:

H1a: Settlement announcements lead to positive short-term equity market and bond market reactions and a tightening of CDS spreads.

H1b: Larger monetary settlement amounts lead to more pronounced market reactions.

The second set of hypotheses relates to the potential systemic effects of lawsuits on the banking sector and the speed of information processing by equity, debt, and credit markets. In line with prior research (e.g., Kwan, 1996; Blanco, Brennan, and Marsh, 2005; Acharya and Johnson, 2007; Norden and Weber, 2009), we anticipate that information processing will

the arrival of the new information and will set share prices below the conditional expected value of this distribution. This is due to investors being risk averse and the uncertainty inherent to the new information. On the surface, this will appear as an initial overreaction to bad news and an underreaction to good news. Subsequently and with the arrival of new and uncertainty reducing information, investors will then increase their valuation as uncertainty is resolved, leading to rising share prices.

${ }^{11}$ Prior literature (e.g., Bizjak and Coles, 1995, Gande and Lewis, 2009, Deng et al. 2014, Karpoff et al. 2017) suggests that the first formal announcement of an investigation is very likely associated with negative capital market reactions. For the purpose of our study we do not analyze the first announcement as it is generally impossible to properly identify the specific date. The original misconduct and the start of the investigations by the relevant authorities into the misconduct is often kept secret and the information, if at all, only gradually diffuses into the market, leading to a lack of a specific date. Frequently, the settlement announcement is also the first official announcement of law enforcement activities. Those studies that investigate the effect of a first formal investigation or lawsuit announcement do this by considering particular cases of enforcement actions, like shareholder class actions, where there are reliable information about the first announcement date. This is, however, not the case for the vast majority of law enforcement actions. 
be fastest in equity and CDS markets, with debt/bond markets taking longer to process the information contained within settlement announcements. Furthermore, we anticipate that market participants update their assessment of the threat of future legal disputes following a settlement. Prior research showed that the announcement of lawsuit filings can generate spillovers to companies of the same industry or from the same home country (e.g., Gande and Lewis, 2009: Huang, Rui, Shen, and Tian, 2017; Choi, Karpoff, Lou, and Martin, 2019). In contrast to these studies, which investigate the announcement of lawsuit filings and find negative effects for the directly affected bank, we investigate the announcement of settlements and generally expect positive effects for the directly affected banks. In this context, the settlement of legal proceedings may lead to positive valuation effects for comparable banks facing similar legal proceedings as uncertainty with regard to the ultimate outcome of their pending legal proceedings is reduced. We therefore hypothesize:

H2a: Equity and CDS markets reflect information contained in settlement announcements faster than bond markets.

H2b: Settlement announcements lead to positive spillover effects to comparable banks facing similar legal proceedings.

We furthermore investigate how resolution announcements impact banks' cash flow and net income. Prior studies that investigate corporate misconduct find that firm performance is reduced in the period following the announcement of fraud compared to the time period prior to the announcement (e.g., Agrawal, Jaffe, and Karpoff, 1999; Tibbs, Harrell, and Shrieves, 2011). However, information on pending enforcement actions on banks usually diffuses into public knowledge well before an official announcement and in some instances it can take more than five years to settle the allegations (Bulan, Ryan, and Simmons, 2016). Given these time frames, it is reasonable to assume that banks make appropriate provisions to account for any pending enforcement actions during the years prior to the settlement. In this case, a bank's net income should remain mostly unaffected by the payment of a 
monetary penalty in the financial year of the resolution announcement. In contrast, since the payment of a penalty is typically due shortly after its announcement, we expect a bank's cash flow to be affected in the financial year of the resolution announcement. This leads to the following hypothesis:

H3: Settlements have a commensurate impact on a bank's cash flow but no effect on its net income in their announcement year.

\section{Data}

\subsection{Database construction and description}

There are no readily accessible public databases for legal resolution announcements of financial institutions. We therefore hand-collect a database of events between 2005 and 2015 that represent a comprehensive number of resolutions of enforcement actions for the 25 largest US and European banks (as determined by either 2004 or 2015 market capitalization) that led to settlements with monetary penalties in excess of $\$ 5$ million 12 . The time period considered covers settlements and fines imposed on banks for their behavior connected to the global financial crisis, but also includes multiple settlements related to prominent other issues, such as the LIBOR scandal. We collect agency press releases, company announcements, and news reports from multiple sources, such as LexisNexis, Bloomberg, and the Wall Street Journal, resulting in a total of 409 events. We take the official announcement of the resolution as the event day given that there is typically no official date prior to the settlement date as most cases are filed the same day as they are settled and information frequently leaks into the market gradually during the investigation period making the identification of the appropriate date of a filing investigation announcement not possible.

The 409 events are distributed among 23 banks from seven different countries 13 Table II

\footnotetext{
${ }^{12}$ We selected this materiality threshold to ensure a minimum economic relevancy and to reliably find the relevant cases through an extensive news search.

${ }^{13}$ Not all of the 25 largest banks had settlements exceeding $\$ 5$ million during our investigation period.
} 
Panel A shows that the sum of the total monetary penalties (TMPs) for all 409 cases amounts to $\$ 285$ billion. The TMP is the sum of all penalties related to the resolution announcement. The mean of $\$ 697$ million is considerably higher than the median of $\$ 154$ million, which is due to some particularly large settlements. Due to our materiality threshold of $\$ 5$ million, the smallest monetary penalty recorded is $\$ 5$ million, while the largest settlement is UBS's $\$ 18.75$ billion agreement with the New York Justice Department for the misrepresentation of securities in August 2008. The relative monetary penalty (RMP) measures a penalty's size relative to the bank's market capitalization and is calculated according to

$$
R M P_{i}=\frac{T M P_{i}}{\text { Market value }_{i}}
$$

where Market value $_{i}$ is bank $i$ 's market value in US dollars six months prior to the settlement. The mean RMP is $0.75 \%$ and the median RMP $0.17 \%$. The maximum RMP in our database is $27.39 \%$ for the $\$ 18.75$ billion UBS agreement. From 2005 to 2015 all banks combined paid $20.46 \%$ of their 2004 year-end market value in financial penalties.

[Place Table II approximately here]

Table II Panel B lists the banks included in our database, ranked according to the sum of the total monetary penalties they incurred during our investigation period (the country of the respective bank's head quarter is given in parentheses). The ranking is led by the big four US banks, Bank of America, JPMorgan Chase, Citigroup, and Wells Fargo, as well as the largest Swiss bank, UBS. The highest TMPs are recorded for Bank of America (\$88 billion). This is partially due to its acquisition of Merill Lynch in 2008 and Bank of America also being held accountable for the legal repercussions of Merill Lynch's business practices preceding the acquisition. JPMorgan Chase resolved the highest number of cases (61) and received the second highest TMPs with $\$ 56$ billion, also including the legal obligations of Bear Stearns which it acquired in 2008. Both banks paid more than $70 \%$ of their 2004 yearend market value in financial penalties. The first non-US bank is UBS, which paid monetary 
penalties of $\$ 25$ billion. The second highest total monetary penalty for a non-US bank are recorded for Deutsche Bank, with TMPs of $\$ 11$ billion 114

A particularity of law enforcement in the US is that corporations are also frequently criminally prosecuted. These criminal cases rarely go to trial and are almost exclusively settled. Table II Panel $\mathrm{C}$ shows a total of 25 criminal agreements and 384 civil settlements. Mean TMPs do not differ materially for both resolution types. The median TMPs show that civil penalties are characterized by a larger variation and the mean of civil penalties is therefore influenced by some exceptionally high TMPs. Considering the RMPs it can be seen that criminal agreements are generally accompanied by larger relative penalties, as shown by the difference in median RMPs. Table II Panel D shows that US authorities in general have more cases than non-US ones, and that total and relative monetary penalties are distinctively higher. Table [I]Panel E shows the sample split according to bank nationality as determined by the banks' head quarters. Nine banks are from the the US. These banks also account for the highest amount of penalties and also paid the highest penalties on average. However, the US banks are also the largest banks in terms of market capitalization and the mean RMP shows that relative to their market value, Swiss, German, French, and Dutch banks paid higher average penalties than their US peers. The five banks from the UK account for the second largest number of cases but with only relatively small average penalties also relative to their market value.

Table II Panel $\mathrm{F}$ shows the number of cases, total, and relative monetary penalties by year. The development of the number of cases and the cumulative total monetary penalties are also illustrated in Figure [1. Considering the number of cases, we observe an upward trend starting in 2010 and reaching its maximum in 2014. The average total and relative monetary penalties peak in 2008, mainly driven by large settlements of UBS, Merrill Lynch,

\footnotetext{
${ }^{14}$ The database also includes three settlements by Lehman Brothers which failed in 2008. These settlements have been reached after Lehman Brothers went into bankruptcy in 2011, 2012, and 2015. Two of them relate to the financial crisis and one relates to the bankruptcy itself. These settlements had to be excluded from the subsequent empirical analysis since there were no stock, bond, or CDS data available.
} 
Citigroup, Goldman Sachs, and Deutsche Bank with the New York Justice Department in connection with the misrepresentation of securities. After a drop in cases and penalties from its peak in 2008, the number of cases, average total penalties, as well as relative penalties, gradually increased until 2013 and 2014. Especially those years see a large number of cases with high average total and relative monetary penalties. This can mainly be attributed to the legal consequences of banking misconduct connected to the financial crisis. $86 \%$ of the penalties in 2014 relate to the wrongdoings connected to the financial crisis. Of all penalties in our sample that are related to the financial crisis, $80 \%$ have been assigned in the three years from 2012 to 2014, accounting for the major portion of the total penalties in those years. In 2015, just $5 \%$ of the penalties relate to the financial crisis, which shows the end of the major legal repercussions for banks. However, the still relatively high numbers of cases, compared to levels prior to 2010, may capture increased banking regulation and scrutiny as a consequence of the crisis. Table II Panels $\mathrm{G}$ and $\mathrm{H}$ show the development of penalties over time, divided by plaintiff nationality. It can be seen that the increase in total, average, and relative monetary penalties can be observed on both sides of the Atlantic, although the numbers are generally considerably smaller in Europe.

The resolution types used most frequently are regulatory fine settlements (121 cases, TMPs of $\$ 35$ billion), public settlements (134 cases, TMPs of $\$ 155$ billion), and class action settlements (82 cases, TMPs of $\$ 43$ billion) 15 Regulatory fines typically lead to smaller monetary penalties. With respect to the major law enforcers, the US Department of Justice, as well as the justice departments of the states, are the most active law enforcers and also impose the largest monetary penalties. Combined, the justice departments enforced 72 cases with aggregate TMPs of $\$ 130$ billion. Another major plaintiff group are investors which sue banks through class actions and interfirm lawsuits. During our investigation period our sample banks resolved 73 cases and paid monetary penalties of $\$ 56$ billion to investors.

\footnotetext{
${ }^{15}$ For reasons of brevity, additional information with respect to the resolution type and plaintiff is provided in Tables A.I and A.II of the Online Appendix.
} 
The Federal Housing Finance Agency (FHFA) resolved comparatively few but large cases in connection to the financial crisis totaling TMPs of $\$ 28$ billion.

\subsection{Sample selection procedure}

In order to obtain a suitable sample for our empirical analysis the original database had to be adapted. Table III documents the sample selection procedure in detail. First, we identified all days on which a bank resolved multiple cases. These 101 redundant cases (cases where a bank resolves at least two cases on a single day) were aggregated into 37 combined multiple cases that summarize all resolutions of a bank on a single day. In order to isolate the effect of the resolution announcement from confounding events, we conducted a thorough LexisNexis news search. We had to drop 62 events from our sample due to confounding events, such as earnings-related news (21 events), M\&A or SEO announcements (12 events), personnel changes (5 events), rating changes (5 events), or other significant events, such as layoffs and major write-offs (total of 19 events). An additional 29 events were excluded due to insufficient quality of stock or bond data. The stock, bond, and CDS data were obtained as end-of-day quotes through Thomson Reuters Datastream. Overall, 94 cases or TMPs with a total of $\$ 62$ billion had to be excluded from the empirical analysis, giving us a final sample of 251 cases and monetary penalties in the amount of $\$ 222$ billion, representing $78 \%$ of the original database. Table IV] offers several descriptive statistics of selected characteristics of our final sample ${ }^{16}$ We obtain the financial statement data from Worldscope and the financial market data from Datastream.17

[Place Table III approximately here]

[Place Table IV] approximately here]

\footnotetext{
${ }^{16}$ Table A.III of the Online Appendix shows the sample of excluded events.

${ }^{17}$ Detailed information on the source, data item code, and calculation of each variable is in Table E.I of the Online Appendix.
} 


\section{Empirical results for directly affected banks}

\subsection{Shareholder wealth effect}

We analyze the short-term shareholder wealth effects of legal resolution announcements using the market model event study method, originally described by Dodd and Warner (1983) and Brown and Warner (1985). The abnormal return $(A R)$ for company $i$ on day $t$ surrounding the announcement day $t=0$ is calculated by:

$$
A R_{i t}=R_{i t}-\left(\hat{\alpha}_{i}+\hat{\beta}_{i} R_{m, i t}\right)
$$

where $R_{i t}$ is the actually realized return of event $i$ 's company on day $t$ and $R_{m, i t}$ is the benchmark index for event $i=18$ The coefficients $\hat{\alpha}_{i}$ and $\hat{\beta}_{i}$ are the regression estimates from an ordinary least squares estimation of the form $R_{i t}=\alpha_{i}+\beta_{i} R_{m, i t}+\epsilon_{i t}$ using a 252 trading day estimation period (one full year) until $t=-11$ and $\epsilon_{i t}$ is the error term. The cumulative abnormal return $(C A R)$ for company $i$ during the event window $\left[\tau_{1} ; \tau_{2}\right]$ is calculated as:

$$
C A R_{i\left[\tau_{1} ; \tau_{2}\right]}=\sum_{t=\tau_{1}}^{\tau_{2}} A R_{i t}
$$

The average cumulative abnormal return $(A C A R)$ for the event window $\left[\tau_{1} ; \tau_{2}\right]$ is then calculated as:

$$
A C A R_{\left[\tau_{1} ; \tau_{2}\right]}=\frac{1}{N} \sum_{i=1}^{N} C A R_{i\left[\tau_{1} ; \tau_{2}\right]},
$$

where $N$ is the number of observations in the sample.

To examine short-term wealth effects and to further reduce the possible impact of confounding events, we focus on the days $t=-1, t=0$, and $t=+1$, as well as the ACARs during the asymmetric short-term event windows $[-1 ; 0]$ and $[0 ;+1]$, so that anticipated and lagged price adjustments are captured. Four different significance tests are used to determine

\footnotetext{
${ }^{18}$ We use the value-weighted Datastream country index of the bank's country of origin as the relevant benchmark.
} 
whether the observed CARs and ACARs are statistically different from zero. We employ the parametric $t$-test and the variance-change corrected standardized cross-sectional test introduced by Boehmer, Musumeci, and Poulsen (1991), the BMP-test. We adjust the test statistic for serial dependence, as suggested by Mikkelson and Partch (1988). This approach is also used in recent studies (e.g., Amici, Fiordelisi, Masala, Ricci, and Sist, 2013; Ricci, 2015). Furthermore, we use two non-parametric tests, the Wilcoxon signed-rank test and the rank test first introduced by Corrado (1989) and later refined by Corrado and Zivney (1992), the CZ-test.

Table $\mathrm{V}$ shows the abnormal stock returns on and surrounding the resolution announcement day for the entire sample of 251 events. One day preceding as well as one day after the announcement the abnormal returns are insignificant. On the announcement day significant average abnormal returns of $0.30 \%$ are observed, supporting hypothesis $\mathbf{H 1 a}$ with regard to a positive equity market reaction to the resolution of legal proceedings. The median CAR is significant and positive as well, providing further support for hypothesis H1a.

\section{[Place Table V approximately here]}

\subsection{Bondholder wealth effect}

We employ a bond event study approach to investigate short-term bondholder wealth effects. Given the previously observed positive shareholder valuation effects and in line with hypothesis H1a we likewise expect a positive bond market reaction. This is driven by bondholders demanding a smaller premium for holding a bank's bond if the resolved legal proceeding reduces uncertainty and are therefore willing to pay a higher price. The general concept of a bond event study is similar to that of the stock event study. However, certain bond characteristics make the bond event study more complex, such as multiple outstanding bonds per company, varying bond maturities and ratings, as well as the absence of a readily available benchmark for the calculation of expected returns. 
We calculate the abnormal bond return $(A B R)$ of bond $j$ by:

$$
A B R_{j t}=B R_{j t}-B R_{M P, j t}
$$

where $B R_{j t}$ is bond $j$ 's return on day $t$ and $B R_{M P, j t}$ is the return of a matching portfolio of bonds, using the bonds' clean prices. We create daily portfolios of all 10,342 liquid bonds of financial institutions available in Thomson Reuters Datastream from 2005 to 2015, resulting in 14 portfolios with an average portfolio size of 410.78 bonds ${ }^{19}$ The bonds are allocated to the portfolios according to their term to maturity and rating. The six rating categories are Aaa-Aa, A, Baa, Ba, B, and below B. The three maturity categories are below the first maturity tertile, the middle tertile, and the upper tertile 20 The matching portfolio return is calculated as the value-weighted sum of the portfolio bond returns. ${ }^{21}$ We use the matching portfolio model as it is considered the most powerful model to detect abnormal returns (Bessembinder, Kahle, Maxwell, and $\mathrm{Xu}$, 2009). It controls for default risk and bond maturity, eliminates rating and maturity as sources of serial cross-correlation among abnormal bond returns (Ederington, Guan, and Yang, 2015), and controls for market-wide term structure change (Maul and Schiereck, 2017).

We condense abnormal bond returns of all banks' outstanding bonds into one abnormal bond return at the bank level (Bessembinder et al., 2009). On average, banks in our sample have approximately 50 bonds outstanding. By building the value-weighted sum of all $A B R s$ belonging to the company of event $i$, we calculate an abnormal bond return of a marketvalue-weighted company portfolio:

$$
A B R_{C P, i t}=\frac{\sum_{j} M V_{j t} A B R_{j t} \delta_{i j}}{\sum_{j} M V_{j t} \delta_{i j}}
$$

\footnotetext{
${ }^{19}$ See Table B.I of the Online Appendix for more details.

${ }^{20}$ The maturity tertiles are calculated on a daily basis and correspond to on average of 2.65 years as cutoff between the first and middle tertile, and 5.66 years as cutoff between the middle and upper tertile.

${ }^{21}$ A detailed description of the matching bond portfolios can be found in Table B.II of the Online Appendix.
} 
where $M V_{j t}$ is bond $j$ 's market value at the end of day $t$ and $\delta_{i j}$ is a binary variable which is equal to one if bond $j$ can be attributed to the company assigned to event $i$, and zero otherwise. We aggregate bonds at the bank level since without aggregation, correlated bank bond returns cause downward shifted standard errors and thereby lead to inflated t-statistics (Eberhart and Siddique, 2002). In addition, only the market-value-weighted approach represents the exact bondholder wealth effect. The cumulative abnormal bond returns $(C A B R)$ during the event window $\left[\tau_{1} ; \tau_{2}\right]$ are calculated as the sum of abnormal bond returns:

$$
C A B R_{C P, i\left[\tau_{1} ; \tau_{2}\right]}=\sum_{t=\tau_{1}}^{\tau_{2}} A B R_{C P, i t} .
$$

We use the average cumulative abnormal bond return (ACABR) to examine the general influence of resolution announcements:

$$
A C A B R_{\left[\tau_{1} ; \tau_{2}\right]}=\frac{1}{N} \sum_{i=1}^{N} C A B R_{C P, i\left[\tau_{1} ; \tau_{2}\right]},
$$

where $N$ is the number of events. To evaluate the statistical significance of the abnormal returns we use standardized and unstandardized t-tests and Wilcoxon signed-rank tests. Abnormal bond returns are standardized with their estimated standard deviation during the $[-10 ;+10]$ event window, excluding the short-term $[-1 ;+1]$ event window. A standardizing of bond returns accounts for heteroskedasticity, which is caused by increasing volatility as bond maturity rises and the bond rating deteriorates (Bessembinder et al., 2009). According to Ederington et al. (2015) both the $t$-test and the Wilcoxon signed-rank test profit from this standardization.

Table VI shows the abnormal bond returns on and surrounding the resolution announcement day. In contrast to the results for the shareholder valuation effect, no significant abnormal returns for bonds are observed on the event day. However, one day after the announcement abnormal bond returns are observed. Significant average abnormal returns of $1.78 \mathrm{bps}$ and $2.36 \mathrm{bps}$ are documented for the day after the announcement and a combination 
of the announcement day and its subsequent day, respectively. This supports hypothesis H1a with regard to bond markets. The median abnormal returns are significant as well. The positive bond returns show that investors now demand a smaller premium for holding a bank's bond and are therefore willing to pay a higher price, which can be explained by reduced uncertainty with respect to the outcome of the enforcement process. In comparison to the stock price reaction, which immediately occurs on the announcement day, the lagged price adjustment of bond prices may stem from less liquid bond trading and can be seen as first tentative evidence in support of hypothesis H2a. Stock prices seem to reflect the new information about the legal enforcement process more quickly and therefore more efficiently, which is in line with prior literature (e. g., Kwan, 1996; Norden and Weber, 2009). In Section 6.1 we investigate the interaction of stocks, bonds, and CDS in more detail.

[Place Table VI approximately here]

\subsection{Determinants of the observed wealth effects}

We examine the drivers of the observed wealth effects through regression analyses using the abnormal stock and bond returns as the dependent variables. We are particularly interested in the impact of the relative monetary penalty on the valuation effect in order to test hypothesis $\mathbf{H 1} \mathbf{b}$. If a reduction in uncertainty dominates investors' valuations and greater uncertainty is associated to larger settlements, we expect larger relative monetary penalties to be accompanied by more positive valuation effects. Furthermore, as a measure of the pre-settlement uncertainty, we look at the stock return volatility leading up to the settlement. We expect higher degrees of pre-settlement uncertainty to be associated with more positive valuation effects. To further control for other possible drivers, three models are being estimated with Model I comprising company-specific variables, Model II case-specific variables, and Model III both. In its full specification (Model III) the regression equation 
for the abnormal stock return has the following form:

$$
\begin{aligned}
\text { AR }_{i 0}= & \alpha+\beta_{1} \lg \left(\text { Asset }_{i}\right)+\beta_{2} \text { Volatility }_{i}+\beta_{3} \text { Cash flow }_{i}+\beta_{4} \text { Net }_{\text {income }} \\
& +\beta_{5} \text { Debt-to-capital }_{i}+\beta_{6} \text { RMP }_{i}+\beta_{7} \text { Multiple }_{i}+\beta_{8} \text { Crime }_{i}+\beta_{9} U S_{i} \\
& +\beta_{10}{\text { Fin. } \text { crisis }_{i}}+\beta_{11} \text { Sov.debtcrisis }_{i}+\epsilon_{i},
\end{aligned}
$$

where $A R_{i 0}$ represents the abnormal stock return on the announcement day $t=0$. We estimate the same model for the cumulative abnormal bond return $C A B R_{i[0 ;+1]}{ }^{22}$ The company-specific variables include the variable $l g$ (Assets), which is equal to the common logarithm of a bank's total assets in US dollars at the end of the year prior to the settlement and controls for firm size effects. The variable Volatility accounts for the recent six-month standard deviation of stock returns and serves as a proxy for uncertainty. The variable Cash flow measures the size of a bank's cash flow divided by its market value, Net income measures its profitability through the ratio of a bank's net income divided by its market value, and Debt-to-capital measures a bank's leverage through its ratio of debt to capital. All three variables relate to the end of the year prior to the event. The case-specific variables include $R M P$, which represents the total monetary size of the settlement divided by the bank's market value six months prior to the settlement announcement. Multiple is a dummy variable which equals one if more than one settlement is announced at the same day for that bank, and zero otherwise. This variable is included as investors may react more positively if several enforcement actions are resolved at the same time. The variable Crime is equal to one if a criminal prosecution is settled, and zero otherwise. This controls for the different characteristics of criminal agreements compared to civil settlements. US is a dummy variable equal to one if a plaintiff or regulator is from the US, and zero otherwise. It captures possible differential wealth effects depending on plaintiff's country of origin. The binary variable

\footnotetext{
${ }^{22}$ We use the $[0 ;+1]$ event day window to account for the lagged bond market reaction observed in the previous section.
} 
Financial crisis is equal to one when the resolution announcement occurs between 2007 and 2011. Similarly, sovereign debt crisis is a binary variable equal to one for events with banks head-quartered in the Euro-zone in 2012 and 2013, and zero otherwise ${ }^{23}$ It controls for the European sovereign debt crisis that followed the financial crisis. The term $\epsilon_{i}$ is a white noise process.

[Place Table VII approximately here]

The results presented in Table VII show that the company-specific characteristics $l g$ (Assets) and Volatility exert a significantly negative and positive influence, respectively, on abnormal stock returns. A one standard deviation increase in each of the variables results in an additional abnormal stock return of $-0.25 \%$ and $0.26 \%$, respectively, indicating that both variables have a similar economic impact. Larger banks thus react less positively to resolution announcements. Shareholders of larger banks could be more confident about the threat of pending legal proceedings beforehand, leading to lower levels of uncertainty and thereby lower relief effects. Besides being significant for stock returns, Volatility is the only variable significantly explaining stock and bond returns alike. For the abnormal bond return, a one standard deviation increase in Volatility results in an additional abnormal bond return of 2.94bps. Investors appear to value uncertainty-reducing information more positively when having been in a particularly uncertain situation. Put differently, settlements have a more pronounced announcement effect when there is a higher potential for uncertainty reduction. ${ }^{24}$ In Model III, the variable Cash flow exhibits a weakly positive and significant influence on abnormal stock returns. A one standard deviation increase in Cash flow causes an additional abnormal stock return of $0.20 \%$. A bank's ability to generate cash flows seems to be of importance as shareholders may be more confident that the payment of penalties will not

\footnotetext{
${ }^{23}$ In 2012 and 2013 there has been a sovereign debt crisis in the Euro-zone member states Greece and Cyprus, respectively (Laeven and Valencia, 2018).

${ }^{24}$ In untabulated results we test the influence of Economic Policy Uncertainty (EPU). To this end we use the EPU measure as introduced by (Baker, Bloom, and Davis, 2016). The results indicate that EPU itself does not influence our results.
} 
hamper a banks future performance. The variable Debt-to-capital has no significant impact on abnormal stock and bond returns. To investigate the effect of bank leverage further, we subdivided our sample of 251 events according to the bank's Debt-to-capital ratio, with one subsample having high Debt-to-capital ratios (above 25th percentile) and the other subsample having low ratios (below 25th percentile). The results can be seen in Tables D.I and D.II of the Online Appendix. The results suggest that highly leveraged banks show more positive stock market reactions to settlement announcements, consistent with the idea that uncertainty resolution is more important for highly leveraged banks.

For stock returns, the case-specific variable $R M P$ has a strong and highly significant influence. Also, the economic impact is comparatively large, as a one standard deviation increase in RMP results in an additional abnormal stock return of $0.38 \% 25$ While we find a positive influence of the relative monetary penalty on shareholder wealth, consistent with the view of reduced uncertainty, the RMP does not influence abnormal bond returns in a statistically significant way. Besides $R M P$, no other case-specific characteristic appear to have a significant influence stock returns. ${ }^{26}$ Looking at the comparatively low explanatory power of Model II for abnormal bond returns, case-specific variables appear to have a limited influence overall. With regard to hypothesis $\mathbf{H 1 b}$, we therefore find strong support for the notion that higher monetary penalties induce more pronounced reactions on the stock

\footnotetext{
${ }^{25}$ In untabulated results we divide the sample according to the relative monetary penalty and conduct an event study for these subsamples. Subsample 1 includes all events with RMPs above the 75th percentile, subsample 2 those below the 25 th percentile, and subsample 3 those in between. For all three samples the major effect is observed on the announcement day. In line with the results of the cross-sectional regression, the highest stock market reaction are observed in the high RMP sample with $0.83 \%$, which is highly significant. The Low RMP sample also exhibits a positive abnormal return of $0.18 \%$ albeit being considerably smaller and only weakly significant. The response of the intermediate RMP sample amounts to $0.10 \%$ and is insignificant. These results may indicate a slightly non-linear, U-shaped relationship between abnormal stock returns and the relative monetary penalty. In the cross-sectional regression, however, a linear relationship proofed to be the best approximation.

${ }^{26}$ In Tables D.I and D.II of the Online Appendix we show the results of subsample event studies which separate the sample into events with US and European law enforcers. In line with the results of the crosssectional regression there is no indication of different stock or bond returns depending on plaintiff nationality. Besides controlling for US plaintiffs, in untabulated analyses we also included binary variables for cross-border resolution announcements, i. e., when a US plaintiff takes enforcement actions against a European defendant and vice versa. This, however, did not lead to any influence on abnormal returns.
} 
market. However, while we can confirm hypothesis $\mathbf{H 1 b}$ with regard to equity markets, we cannot confirm it with regard to bond markets.

In our regressions on abnormal stock returns, we also include dummy variables to assess the influence of the type of resolution and the law enforcer. The results are presented in Tables C.I and C.II of the Online Appendix ${ }^{27}$ Although enforcement actions have considerably heterogeneous characteristics depending on the resolution type, these types have only very limited explanatory power for abnormal stock returns (see Table C.I of the Online Appendix) and therefore seem to be of limited relevance for stockholders. This underscores the importance of the other significant variables, i. e., lg(Assets), Volatility, and the RMP, which are major determinants of shareholder valuation effects. However, we observe significantly more negative shareholder valuations of non-prosecution agreements of $-0.98 \%$ (column $\mathrm{V}$ of Table C.I . Combined with the negative coefficient for deferred prosecution agreements (column VI) and the positive one for plea agreements (column IV) this points in a similar direction as previous findings by Flore et al. (2017), who show that in the context of criminal prosecutions shareholders generally value the announcement of plea agreements more positively in comparison to pretrial diversions. Considering the influence of different plaintiffs on shareholder valuation effects (see also Table C.II of the Online Appendix), we see that the resolution of enforcement actions by the DOJ result in weakly significant but larger announcement effects of $0.56 \%$ compared to other plaintiffs (column I). Furthermore, resolution announcements concerning actions by the OCC, which enforces safety and soundness regulation and regulates systematic risk, lead to a generally smaller announcement effect of $-0.68 \%$ (column V).

\footnotetext{
${ }^{27}$ In untabulated results we investigated the influence of the defendant bank and the year of settlement on abnormal stock returns. We observed a significantly more positive resolution valuations by Bank of America's shareholders, with $0.75 \%$ higher abnormal stock returns on the day of a resolution announcement. The shareholders of Deutsche Bank, on the other hand, are significantly more pessimistic with $-0.53 \%$ abnormal returns. Year-specific valuation effects are generally not observed, except for weakly significantly smaller valuation effects in 2006.
} 


\subsection{Effect on CDS spreads}

We additionally investigate whether settlement announcements impact banks' CDS spreads. Prior research shows that CDS spreads efficiently measure the underlying company's default risk (e.g., Longstaff, Mithal, and Neis, 2005) and are therefore an appropriate tool to test the impact of the resolution of legal proceedings on the perceived default risk of banks. In line with hypothesis H1a, we expect that the resolution of legal proceedings leads to a tightening of CDS spreads, as a reduction in uncertainty leads to a reduction of default risk. We collect the CDS data for our sample of financial institutions through Thomson Reuters EOD. Following prior literature (e. g., Galil and Soffer, 2011; Jorion and Zhang, 2007; Kiesel, Kolaric, and Schiereck, 2016; Norden, 2017), we take the five-year senior CDS mid-spread in US dollars, which is generally considered the most liquid CDS contract. We use spread changes $\left(S C_{i t}\right)$, which present the daily change in credit default swap spreads of the bank belonging to event $i$. We compute abnormal CDS spread changes (ASCs) following the approach of, among others, Galil and Soffer (2011) and Norden (2017), by adjusting observed CDS spread changes by the spread change of a matching portfolio $\left(S C_{M P, i t}\right)$ :

$$
A S C_{i t}=S C_{i t}-S C_{M P, i t}
$$

The cumulative adjusted CDS spread changes for the $[-1 ; 0]$ and $[0 ;+1]$ event windows are calculated by summation of the daily $A S C s\left(C A S C_{i\left[\tau_{1} ; \tau_{2}\right]}=\sum_{t=\tau_{1}}^{\tau_{2}} A S C_{i t}\right)$ and the average cumulative spread changes are calculated as the average of all sample banks' CASCs $\left(A C A S C_{\left[\tau_{1} ; \tau_{2}\right]}=\frac{1}{N} \sum_{i} C A S C_{i\left[\tau_{1} ; \tau_{2}\right]}\right)$. The daily CDS portfolios are computed as the equally weighted cross-sectional mean of all 211 banks with available CDS data through Reuters EOD and a long-term issuer rating by Standard and Poor's or Moody's, excluding the event firm. In total, six portfolios are constructed representing the six rating categories Aaa-Aa, $\mathrm{A}, \mathrm{Baa}, \mathrm{Ba}, \mathrm{B}$, and below $\mathrm{B}{ }^{28}$ The $A C A S C s$ are tested for significance using the parametric

\footnotetext{
${ }^{28}$ Table $\mathrm{B} . \mathrm{I}$ in the Online Appendix shows the average portfolio size.
} 
t-test and the nonparametric Wilcoxon signed-rank test.

The results of the CDS event study are shown in Table VIII. We observe a highly significant tightening of CDS spreads of approximately -0.71bps on the announcement day of resolved legal proceedings, supporting hypothesis H1a of positive valuation effects with respect to the CDS market. It is noteworthy that CDS spreads react immediately to the announcement of the resolution of legal proceedings, while the observed abnormal bond returns largely take place on the day following the event. This indicates a faster and more efficient information processing in the CDS market. This is in line with prior literature (e.g., Blanco et al., 2005; Acharya and Johnson, 2007) and provides further evidence in support of hypothesis H2a. The results of the CDS event study provide further support for the assumption of reduced uncertainty following the official announcement of the resolution of legal proceedings against a financial institution. To investigate the cross section of CDS spreads, we further separated our 251 events according to plaintiff nationality (US vs. European) and banks' debt-to-capital ratio (lowest $25 \%$ vs. highest $25 \%$ of sample) ${ }^{29}$ The results are documented in Tables D.I and D.II of the Online Appendix. As for the stock and bond market, there is no indication that the cross-section of CDS spreads can be explained by the plaintiff nationality. With respect to bank leverage, similar to the stock market, there is some evidence that more highly levered banks react more positively, i. e., have a more negative spread reaction. Mean and median abnormal spread changes are significantly more negative on the announcement day for banks with a leverage above the 25th percentile (mean of $-1.56 \mathrm{bps}$ ) compared to banks below the 25 th percentile (mean of $-0.17 \mathrm{bps}$ ) of our sample. This substantiates the tentative findings from the stock market that banks with a higher leverage react more positively to the settlement announcement of legal proceedings. The effect of relief might be more pronounced as highly leveraged banks are riskier and the

\footnotetext{
${ }^{29}$ In untabulated results we conducted a cross-sectional regression analysis of the abnormal CDS spreads analogous to the ones in Subsection 5.3 for stock and bond markets. The results, however, show no significance and generally the cross-section of CDS spreads seems to be difficult to explain as indicated by very low coefficients of determination.
} 
resolution of uncertainty for them could be more important.

[Place Table VIII] approximately here]

The results from the stock, bond, and CDS event studies overall confirm hypothesis H1a of generally positive valuation effects. With regard to the hypothesized influence of the monetary size of the penalty $(\mathbf{H} \mathbf{1 b})$, the results provide strong support for the stock market, where the effect of higher penalty sizes leading to more positive valuations is quite pronounced. However, similar reactions cannot be confirmed for the bond or CDS market. The event study results also provide first tentative support for hypothesis $\mathbf{H 2 a}$, as the speed of information processing appears to be faster in the equity and CDS market than in bond market. This will be further analyzed in the next section.

\section{Propagation of penalties through financial markets}

\subsection{Interdependency of stocks, bonds, and CDS around settlements}

In this section we examine the general interdependence of stock returns, bond returns, and CDS spread changes to examine their timely interaction and succession around resolution announcements. The aim is to assess whether certain types of financial instruments lead others and thereby test hypothesis H2a. The results so far suggest that stock and CDS markets react immediately to the announcement of the resolution of legal proceedings, while bond markets lag by one day, providing first evidence in favour of hypothesis $\mathbf{H 2 a}$.

In order to analyze the interdependency of these three markets, we estimate a simultaneous equation model as shown in Equations 11, 12, and 13. We are particularly interested in the influence of lagged variables and event-time fixed effects around the settlement date. By incorporating lagged variables we are able to test lead-lag relationships between the markets and by testing the significance of event-time fixed effects we are able to substantiate our previous results while also controlling for market interdependencies. We also allow for contemporaneous interaction of markets. For this reason we estimate our coefficients following 
a two-stage least squares estimation procedure. We add settlement fixed effects to control for the heterogeneity of enforcement actions. In addition, time fixed effects for the event day and the two days preceding and following the event day are included. The standard errors used to calculate the $t$-statistics are clustered by settlement to account for cross-sectional correlation.

$$
\begin{array}{r}
R_{i t}=\alpha_{1}+\beta_{11} R_{m, i t}+\beta_{12} B R_{i t}+\beta_{13} S C_{i t}+\beta_{14} R_{i t-1}+\beta_{15} B R_{i t-1}+\beta_{16} S C_{i t-1}+ \\
\gamma_{1 t} A_{t}+v_{1 i}+\epsilon_{1 i t}, \\
B R_{i t}=\alpha_{2}+\beta_{21} B R_{M P, i t}+\beta_{22} R_{i t}+\beta_{23} S C_{i t}+\beta_{24} R_{i t-1}+\beta_{25} B R_{i t-1}+\beta_{26} S C_{i t-1}+ \\
{ } C_{i t} A_{t}+v_{2 i}+\epsilon_{2 i t}, \\
\alpha_{3}+\beta_{31} S C_{M P, i t}+\beta_{32} R_{i t}+\beta_{33} B R_{i t}+\beta_{34} R_{i t-1}+\beta_{35} B R_{i t-1}+\beta_{36} S C_{i t-1}+ \\
\gamma_{3 t} A_{t}+v_{3 i}+\epsilon_{3 i t} .
\end{array}
$$

The dependent variables $R_{i t}, B R_{i t}$, and $S C_{i t}$ are a bank's stock return, bond return, and CDS spread change for event $i$ at the time $t: 30$ In order to control for general market movements we include $R_{m, i t}, B R_{M P, i t}$, and $S C_{M P, i t}$, which correspond to the domestic stock market return, the bond return of a portfolio matched according to bond rating and maturity, and the spread change of a CDS portfolio matched according to credit rating ${ }^{31}$ We consider the same 251 resolution announcements as for the previous analyses and the time dimension spans 273 days, from 262 days prior to until 10 days following the resolution announcement. In order to control for the interdependence of stock and bond returns, as well as CDS spread changes, we include their contemporaneous values $R_{i t}, B R_{i t}, S C_{i t}$, as well as their lagged values $R_{i t-1}, B R_{i t-1}$, and $S C_{i t-1}$ in all three regressions. Time fixed effects for the resolution

\footnotetext{
${ }^{30}$ The bond return is calculated as a value-weighted return of all outstanding bonds of a bank.

${ }^{31}$ Stock and bond returns, as well as spread changes are calculated as differences of unit root processes. Therefore, they generally meet the stationarity condition. Conventional unit root tests for panel data show that all time series are stationary (Choi, 2001; Levin, Lin, and Chu, 2002, Im, Pesaran, and Shin, 2003).
} 
announcement are included with the term $\gamma_{t} A_{t}$, where $A_{t}$ is equal to one for $t \in\{-1,0,+1\}$, and zero otherwise. The coefficient $\gamma$ therefor measures the abnormal return surrounding the resolution announcement which cannot be explained by general market movements or market interdependencies. Settlement fixed effects are embodied by $v_{i}$ and $\epsilon_{i t}$ is a white noise process.

[Place Table IX] approximately here]

The estimated coefficients of Equations 11 to 13 are shown in Table IX as column I. Column II always provides estimation results excluding the interconnection of markets as a baseline. All six regressions show a statistically significant and positive influence of the contemporaneous stock benchmark return, the matching portfolio bond return, and the matching portfolio CDS spread change, respectively. This underscores the importance of general market movements to daily stock and bond returns as well as CDS spread changes. Since we previously used these market benchmarks for the calculation of expected returns and spread changes for the event studies, this also substantiates this method's adequacy. ${ }^{32}$ Concerning the endogenous effects we observe a comprehensive interconnection of markets. Only the bond market seems to have a more limited contemporaneous relevance especially for stock returns, where the influence is insignificant. By considering the estimated coefficients of the lagged variables we are able to test lead-lag relationships between the markets. For stock and bond markets it appears that stock markets lead bond markets as previous day's stock returns influence today's bond returns but not vice versa. Between bond and CDS markets no clear lead-lag relationship emerges and we cannot reject the hypothesis that both markets lead each other, although the lead relationship of the CDS market is more

\footnotetext{
${ }^{32}$ The coefficient of 1.47 for $R_{m, i t}$ presents a measure of the systematic market risk of an average bank of our dataset and shows a strong influence of general market conditions on the stock returns of our banks. While $R_{m, i t}$ represents the return of the overall domestic stock market, $B R_{M P, i t}$ and $S C_{M P, i t}$ do not refer to the general market, but to other financial institutions. We estimate a coefficient of 0.32 for a matching portfolio bond return and thereby observe a attenuated influence of other institutions' bond returns. For the matched portfolio of CDS spreads, however, with a coefficient of 3.93 we see very strong dependence. This difference may be explained by a slower reaction of bonds compared to stocks and CDS.
} 
distinctive. This is likely due to the high degree of relatedness of these two markets. For the bond market the default risk is a major determinant of bond returns while CDS are a more direct measure of this default risk.

With respect to the event-time fixed effects around the announcement day, a significant increase in stock returns of $0.25 \%$ and a significant decrease of CDS spreads of $-0.58 \mathrm{bps}$ is documented on the event day for Model I. The time fixed effects of Models I and II do not deviate in a meaningful manner. The coefficients are comparable to the average abnormal stock return of $0.30 \%$ in Table $\mathrm{V}$ and the average abnormal CDS spread change of $-0.71 b p s$ in Table VIII, further substantiating these results. The bond returns, however, do not exhibit significant event-time fixed effects on the announcement day or the following day for the comprehensive Model I. In Model II there are significantly positive time fixed effects for the day following the settlement which is in line with our previous results from the bond event study. Hence, the previously observed announcement effect on the bond market gets absorbed by the influences of the stock and CDS market onto the bond market. These results confirm the notion that stock and CDS movements are leading bond returns and show that the observed valuation effect of a settlement announcement is transmitted to the bond market through the stock and CDS markets rather than immediately affecting the bond market. The previous day's stock return and CDS spread change already account for the announcement effect on day $t=0$ and subsequently translate this effect into the bond market, thereby confirming hypothesis H2a.

\subsection{Spillover effects of settlement announcements}

We further investigate whether settlement announcements lead to spillover effects to comparable financial institutions that likewise have global operations. ${ }^{33}$ We consider as "comparable" all sample banks that do not have a resolution announcement on the same

\footnotetext{
${ }^{33}$ The financial institutions in our sample are among the largest banks globally, are important in their respective home country. They have global operations in multiple areas of banking and, given their global footprint, are subject to the same regulators and law enforcers.
} 
day or the two days surrounding it 34 The comparable institutions' abnormal stock returns are obtained in the same fashion as the affected banks' abnormal returns, using the market model, the value-weighted Datastream country index of the bank's country of origin, and a 252-day estimation period ending 11 days prior to the event day. This leads to a total sample of 3,415 institutions for 196 event days (see Table X ${ }^{35}$ Table $\mathrm{X}$ shows that positive wealth effects can be observed: on the event day and during the $[0 ;+1]$ event window significant and positive average abnormal returns of $0.07 \%$ and $0.09 \%$ are documented, respectively. The median CAR however is close to zero. In Table XI we study the drivers of comparable banks' abnormal returns on the day of the announcement. As before, we employ companyspecific and case-specific variables as potential determinants. We include a new case-specific variable, "In formational spillover", which equals one if a comparable bank has a settlement with the same plaintiff during the following two years after the settlement with the sued bank, and zero otherwise. We take a two year window to capture whether the comparable banks face similar lawsuits with the same plaintiff. Based on column III, we observe that information from the behavior of a plaintiff generates positive spillovers towards comparable banks, i. e., a $0.20 \%$ positive abnormal return towards comparable banks being subject to the same plaintiff. Multiple announcements on the same day and settlements in crisis years also generate positive shareholder valuation effects for for these comparable banks. We also see a weakly significant and positive effect of the relative monetary penalty indicating a more positive reaction in case of larger relative settlement sizes. This is consistent with the hypothesis $\mathbf{H} \mathbf{2} \mathbf{b}$ that positive spillover effects exist and that the settlement of a sued bank not only reduces uncertainty for that bank but also for similar banks facing pending lawsuits with the same plaintiff. The results therefore document that the resolution of enforcement actions has knock-on effects beyond the directly affected bank and show how

\footnotetext{
${ }^{34}$ Table B.I in the Online Appendix shows the minimum and maximum numbers of comparable banks per event, 14 and 19, respectively, and the median number, 18.

${ }^{35}$ The reduced number of events in comparison to the stock and bond event study is due to some of the previously analyzed 251 events taking place on the same day. Since the spillover effects to comparable banks of multiple events during a day cannot be separated, these events were aggregated.
} 
capital market participants process information to update their expectations. Our findings of positive knock-on effects to comparable banks with similar pending lawsuits underscore the systemic importance of law enforcement against banks. They also show that the settlement itself creates positive effects within the banking industry, consistent with reduced uncertainty surrounding the settlement.

[Place Table $\mathrm{X}$ approximately here]

[Place Table XI approximately here]

\section{Effect on banks' financial statements}

How does a resolution announcement impact on a bank's financial statement, more specifically, a bank's liquidity, profitability, capital adequacy, and lending creation? If reduced uncertainty is the main driver of the positive wealth effects, investors should already have anticipated the payment of a penalty beforehand. Investors' expectations are, however, hard to measure. Therefore, we study banks' financial statements as a proxy. It can be argued that if a bank correctly estimates pending legal obligations in the context of its financial reporting, shareholders will have done so as well. Typically, enforcement actions associated with larger penalties last well over one year, largely due to the complexity of the investigated cases. With the exception of class actions, it is difficult to determine the exact time at which the enforcement action first became public knowledge. For class actions in general, the median time from the filing date to settlement was three years for all cases settled in 2015, while those cases with the highest settlement amounts took well above five years to settle (Bulan et al., 2016). While class action settlements only account for roughly $20 \%$ of cases in our database, this can still serve as a proxy for the time period between the discovery of a misconduct and the resolution through a settlement. Because information about pending enforcement activities are usually known well before the financial year of their resolution it 
is reasonable to assume that banks made adequate provisions for the potential resolution during previous financial years ${ }^{36}$ Therefore, following H3, we hypothesize that a bank's net income should be unaffected by the payment of a monetary penalty in the financial year of the resolution announcement. In contrast, since the payment of the penalty is typically due shortly after its announcement, we expect the cash flow of a bank to be commensurately affected in the financial year of the resolution announcement. We further investigate the effect on a bank's tier 1 ratio and its year over year lending growth. Two opposing forces could be at work. First, resolution of uncertainty may lead to favorable impacts on bank outcomes such as tier 1 ratio and its year over year lending growth. Indeed, there is an emerging body of literature showing that general economic policy uncertainty (EPU) has a significant effect on bank lending ${ }^{37}$ Although EPU and bank-specific legal uncertainty are quite different, the finding that economic policy uncertainty leads to less lending may be taken as an indicator that bank-specific uncertainty with respect to the final outcome of legal proceeding may also curtail bank lending. In this spirit, the resolution of this uncertainty may increase bank lending leading to a significant influence of the resolved penalties in a given year on this year's lending growth. Second, bank fines may negatively impact bank's capital ratios and curtail its lending capacity.

We use a panel regression model on bank-year-basis to investigate whether there is a significant interdependency between the relative monetary penalties a bank paid in a specific year and the bank's cash flow, net income, tier 1 ratio, and lending growth. The standard

\footnotetext{
${ }^{36}$ There is anecdotal evidence on the level of provisions bank make for specific enforcement actions (e.g., Freifeld, Viswanatha, and Henry, 2013, Glazer, 2014). However, banks generally do not disclose their reserves for pending enforcement actions.

${ }^{37}$ For example, Bordo, Duca, and Koch (2016) show that EPU has a negative effect on bank credit growth, thereby curtailing economic growth more generally. Berger, Guedhami, Kim, and Li (2020) similarly show that EPU leads to reduced liquidity creation by banks. The effect of general economic policy uncertainty on a bank's behavior is different from uncertainty resolutions in bank-specific legal proceedings. While both situations involve the effect of uncertainty, economic policy uncertainty is of a general nature affecting banks indirectly. Uncertainty with respect to a bank's legal proceedings, however, affects this bank directly.
} 
errors are clustered by bank.

$$
\begin{aligned}
\text { Cash flow }_{i t}= & \alpha+\beta_{1} \text { RMP }_{i t}+\beta_{2} \lg \left(\text { Assets }_{i t}\right)+\beta_{3} \text { Revenue }_{i t}+\beta_{4} \text { Cash }_{i t}+ \\
& \beta_{5} \text { Debt-to-capital } \\
i t & +\beta_{6} \text { Market-to-book }_{i t}+\gamma_{t}+v_{i}+\epsilon_{i t} .
\end{aligned}
$$

The dependent variable Cash flow $i t$ represents bank $i$ 's operating cash flow, divided by its market value at the end of year $t$. We also use $N$ et income $_{i t}$, Tier 1 ratio $_{i t}$, and Loan growth $_{i t}$ as other dependent variables. Net income $i t$ represents bank $i$ 's net income, divided by its market value at the end of year $t$, Tier 1 ratio $_{i t}$ represents bank $i$ 's ratio of tier 1 capital to total risk-weighted assets at the end of year $t$, and Loan growth $h_{i t}$ represents bank $i$ 's total loan growth from year $t$ over year $t-1$. The explanatory variables $R M P_{i t}$, Revenue $i t$, and Cash $_{i t}$ relate to bank $i$ 's total monetary penalties paid during year $t$, its revenue, and cash at the end of year $t$, all divided by bank $i$ 's market value at the end of year $t . \lg \left(\right.$ Assets $\left._{i t}\right)$ relates to bank $i$ 's common logarithm of total assets at the end of year $t$. Debt-to-capital ${ }_{i t}$ is bank $i$ 's ratio of total debt and total capital at the end of year $t$, and Market-to-book $k_{i t}$ is bank $i$ 's market value of common equity, divided by its book value of common equity at the end of year $t$. Descriptive statistics for these panel variables are shown in Table A.IV of the Online Appendix. Year fixed and bank fixed effects are denoted by $\gamma_{t}$ and $v_{i}$, respectively. The error term $\epsilon_{i t}$ is a white noise process.

\section{[Place Table XII approximately here]}

The estimation results are shown in Table XII. Columns I and II include year fixed effects and year fixed as well as bank fixed effects, respectively. The regressions with the annual Cash flow as the dependent variable show a significant influence of the relative monetary penalty, supporting hypothesis H3 with regard to a bank's cash flow. Given the usage of the same scaling variable for the dependent and independent variable, the results imply that a one US dollar increase in the total monetary penalty translates into a -1.04 (column II) US dollar decrease in operating cash flow. This underscores the cash flow-effectiveness 
of monetary penalties, which reduce annual cash flows nearly one-to-one. The regression estimates for the equations with Net income as the dependent variable show distinctively smaller coefficients which are also statistically insignificant, confirming hypothesis $\mathbf{H 3}$ with regard to a bank's net income. Therefore, penalties paid by a bank seem not to be incomeeffective in the fiscal year resolutions are announced, while penalties are cash flow-effective in the same fiscal year. This result provides evidence that banks and, at least to a certain degree, investors are generally able to correctly anticipate the size of impending financial penalties, confirming hypothesis H3. Resolved uncertainty, however, leads to a positive valuation of law enforcement resolution even if penalties are correctly anticipated.

We also estimate regressions with the Tier 1 ratio as the dependent variable to further examine, whether penalties have an effect on a bank's capital ratio. Table XII shows that the tier 1 ratio is unaffected by resolution announcements in the same year. This suggests that legal penalties have no direct effect on a bank's capital adequacy when they are announced. This should alleviate concerns with regard to the announcement of bank fines or the resolution of legal proceedings potentially leading to an increase the riskiness of financial institutions. We furthermore investigate the effect of yearly paid penalties on lending during that same year by using the year over year growth rate in total loans. We find no evidence that suggests that the announcement of financial penalties influences the lending creation of banks in the year they are announced. This alleviates concerns that the uncertainty connected to pending enforcement actions may curtail bank lending.

\section{Penalties and banks' systemic risk}

What effect do financial penalties have on the systemic risk of banks? This is a particularly interesting question for regulators, who aim to reduce the systemic risk externalities generated by banks. Financial penalties could be a way for regulators to make banks internalize the costs associated with systemic risk. To address this question we study the effect of annually paid penalties on the three most central metrics derived from financial market 
data in the systemic risk literature, $\triangle$ CoVaR, MES, and SRISK (Benoit, Colliard, Hurlin, and Pérignon, 2017).

These three measures have different perspectives on systemic risk. $\Delta$ CoVaR measures to which degree banks are inducers of systemic risk in the financial system, while MES and SRISK treat banks a risk recipients (Brunnermeier, Rother, and Schnabel, 2020). $\Delta$ Co VaR is the conditional value at risk of the financial system conditional on a bank being under distress in excess of the CoVaR of the financial system conditional on a bank's median state as proposed by Adrian and Brunnermeier (2016). VaR is expressed in terms of the growth rate of market valued financial assets and a bank is defined to be under distress if its growth rate of market valued financial assets is at its VaR level. MES is the marginal expected shortfall and is based on the expected shortfall (ES) which represents the expected equity losses of a bank conditional on the financial system being under distress as proposed by Acharya, Pedersen, Philippon, and Richardson (2017). Instead of only considering the loss at a specific point of the risk distribution's tail, as done by the value at risk measure, the expected shortfall takes into account the whole tail by looking at the expected loss conditional on the loss being greater than the VaR. The marginal expected shortfall then is the increase in the risk of the financial system, measured by the its expected shortfall, induced by a marginal increase in the weight of a bank in the system. SRISK measures a bank's capital shortfall dependent on the financial system being under distress measured by a severe market decline as proposed by Acharya, Engle, and Richardson (2012) and Brownlees and Engle (2017). A severe market decline is defined as a cumulative market return below a specific threshold within a specific time period. Through the consideration of bank size and leverage, SRISK reflects the capital shortfall of a bank and can be thought of as an extension of the MES, more specifically the long run MES, which considers a bank's equity shortfall. We sum up the SRISK of the whole financial system which is equivalent to the total amount of capital a government had to provide to bail out the entire financial system. We then express a bank's SRISK in percentage terms as the share of a bank's SRISK in US 
dollars from the SRISK of the whole financial system.

For the calculation of $\triangle \mathrm{CoVaR}$ and MES we set the risk level for the value at risk at $95 \%$ and for the calculation of SRISK we set the capital adequacy ratio at $8 \%$ and define a severe market decline as a market return of $-40 \%$ and less over a period of 6 months. For the calculation of the financial system return as well as the SRISK in percentage terms we furthermore define two financial systems in the United States and Europe. These financial systems consist of all financial institutions in Thomson Reuters between 2005 and 2015 that are head-quartered in the respective areas and have information on stock price, market capitalization, stocks outstanding, book equity, and total assets available in Datastream and Worldscope, respectively ${ }^{38}$ Following Brownlees and Engle (2012) we model time varying conditional variances and correlations using a GARCH-DCC model to estimate daily MES and SRISK values, as well as the return volatility for the $\Delta$ CoVaR calculation (e.g., Benoit et al. 2017). To compute daily $\Delta \mathrm{CoVaR}$ values we employ quantile regressions, as originally suggested by Adrian and Brunnermeier (2016).

We use a panel regression model on bank-year-basis to investigate whether there is a significant influence of the relative monetary penalties a bank paid in a specific year and the bank's systemic risk in the following year. The regression model is similar to Equation 14 but the dependent variables are $\Delta C o V a R_{i t+1}, M E S_{i t+1}$, and $S R I S K_{i t+1}$, respectively. All three systemic risk variables relate to the mean of daily values of bank $i$ in year $t+1$. The independent variables are the same as for the panel regression in the previous chapter and likewise relate to their values at the end of year $t$. The independent variables are thereby lagged by one year relative to the dependent variables. The standard errors are clustered by bank. Descriptive statistics for the systemic risk measures as well as the independent variables are shown in Table A.IV of the Online Appendix.

\footnotetext{
${ }^{38}$ For the United States the financial system comprises approximately 989 financial institutions on average per year from 2005 to 2015. For Europe the financial system comprises approximately 470 financial institutions on average per year during the same time period.
} 
[Place Table XIII approximately here]

The estimation results are shown in Table XIII. Models I and II include year fixed effects and year fixed as well as bank fixed effects, respectively. The explanatory variable of interest is $R M P_{i t}$ which is the sum of all monetary penalties of bank $i$ in year $t$ divided by the bank's market value at the end of year $t$. While there is no significant effect of the $R M P$ on the $\triangle C o V a R$ and $M E S$ of the following year, there is a highly significant and positive effect of penalties on SRISK in Model I that only controls for year fixed effects. So while larger penalties seem to increase bank's systemic risk, this relationship vanishes when including bank fixed effects (Model II). This suggests that the RMP is highly correlated with the bank fixed effects and seems less important in explaining systemic risk changes over time within the same bank. Our findings could still be taken as a cautious indicator that banks with a higher RMP in the current year have a higher percentage share of SRISK in the following year.

\section{[Place Table XIV] approximately here]}

Reverse causality between SRISK and RMP happens when plaintiffs take into account the systemic risk of banks when handing out penalties. In Table XIV, we therefore show the results of panel regressions where we use the systemic risk measures to explain the relative monetary penalties paid in the following year. The variable definitions remain the same as for the previous regressions only that the $R M P$ now is the dependent variable and relates to year $t+1$ and the systemic risk measures are independent variables relating to year $t$ as the other dependent variables. We see the same pattern as in Table XIII before. In all regressions the influence of the systemic risk variables on next year's $R M P$ is insignificant but for Model I for the variable SRISK. Considering the results of Model I this indicates that law enforcers hand out higher fines to banks with a larger share of systemic risk in the financial system. This is a particularly interesting observations as systemic risk poses an externality for banks and assigning penalties based on the size of this externality may be a 
form of intervention that aims at assigning costs in order to align incentives, as suggested by Acharya and Johnson (2007). Considering Models I of Tables XIII and XIII, systemic risk and regulatory penalties seem to be interdependent and reinforce each other over time. While higher values of $S R I S K$ increase the likelihood of higher $R M P$ 's in the following year, higher $R M P$ 's themselves increase the likelihood of a higher SRISK measure one year later. These results however do not survive when we include bank fixed effects. This suggests that there are observed and unobserved bank fixed characteristics that do a better job of explaining next year's $R M P$ and $S R I S K$ measures. We therefore take these overall results as weak evidence for the interdependence of SRISK and RMP, which calls for a separate analysis before being able to draw robust conclusions.

\section{Conclusion}

Banks have been subject to major financial penalties over the last decade. To provide a holistic overview of the impact of financial penalties on banks, we test several hypothesis, relating to the impact on stock, bond, and CDS markets, the speed of information processing in these markets, potential spillovers to comparable financial institutions, and the effect on a bank's cash flow and net income. To this end, we use a unique data set of legal settlements of the largest global financial institutions between 2005 and 2015, using a sample of 251 distinct events. Given that the banking sector plays central role to the economy, it is of particular importance to gain a first understanding of the effect of legal proceedings and their subsequent settlements on a banks default risk as well as potential systemic spillover effects.

We find that, on average, the settlement of enforcement actions is perceived as positive news. A bank's stock valuation increases and the perceived default risk is lower as shown by lower bond yields and a tightening of CDS spreads. Larger monetary settlements lead to more pronounced equity market reactions, suggesting that these are associated with greater reductions of uncertainty. Further substantiating this result, we observe that banks with 
greater stock return volatility prior to the settlement enjoy larger announcement effects in stock markets. Our results further indicate that stock and CDS markets directly react to the resolution of enforcement actions and then transmit the effect to the bond market which reacts indirectly with a lag of one day.

The impacts of legal settlements is not confined to the bank receiving the penalty. We find that the resolution of legal proceedings leads to positive valuation effects for comparable financial institutions with pending lawsuits with the same regulator or law enforcement entity. These results suggest that the unraveling of bank fines appears to be associated with positive spillovers. On the one hand this underscores the systemic importance of legal proceedings against banks, on the other hand this should also alleviate concerns with regard to the settlements' systemic impact. At the same time, employing three different measures for the sued bank's contribution to systemic risk, we find weak evidence for an increase of that bank's contribution to systemic risk in the size of the relative monetary penalty. This mixed evidence underscores the systemic relevance of law enforcement actions against banks, as pointed out by the European supervisory authorities (European Systemic Risk Board, 2015).

Finally, we find that monetary penalties reduce a bank's annual cash flow nearly one-toone in the year they are announced, reflecting the cash flow-effectiveness of these settlements. In the year of the resolution announcement, however, the bank's net income is unaffected by the announced penalties. This provides tentative evidence that banks on average correctly anticipate the impending financial penalties in previous financial years and substantiates the notion that the positive valuation effects by stock, bond, and CDS market participants are driven by the resolution of uncertainty.

Large, global financial institutions operate in a unique regulatory environment where the number of regulators and/or enforcement agencies is higher than for most other industries, with local, national, and supranational regulators. Global financial institutions also differ compared to other globally operating firms, such as airlines and utilities, as they can gen- 
erate systemic risk. Fines and penalties are imposed on banks for misconduct that led to financial damages. Imposing large monetary penalties can therefore be an effective measure to obtain compensation from banks for their misconduct. Simultaneously this may serve as a deterrent against future misconduct. However, even though the height of the penalty should reflect the magnitude of the misconduct, the penalized institution may face other repercussions (e.g., reputational damage, loss of future business opportunities, rating downgrades, etc.) necessitating authorities to balance the penalty with the bank's capability to pay the penalty without endangering its operations. Otherwise, the penalty may have unintended consequences that may endanger the bank's existence. Our study shows that regulatory investigations lead to significant uncertainty that is only resolved once the bank reaches a settlement with the authorities. Further studies could test whether the imposed penalties resulted in significant governance changes at the penalized bank and therefore lead to fewer occurrences of misconduct. Additionally, future research could investigate whether penalty size is an effective deterrent or whether other measures, such as criminal prosecution of individuals directly involved in the misconduct, decreases the likelihood of other banks engaging in similarly fraudulent activities. 
Table I: Major US and European regulators and law enforcers.

This table shows the major US and European regulators, public law enforcers, as well as private plaintiffs similar to Jickling and Murphy (2010). The activities of the federal and state-level Justice Departments (DOJ, State DOJ) play a major role in banking law enforcement and are summarized in Panel A under General law enforcement. The regulatory regime can be generally divided into two types of regulators. Panel B lists the major Financial institution regulators, which regulate particular types of institutions for risky behavior or conflicts of interest. Panel C lists the major Financial market regulators, which promulgate rules for certain financial transactions no matter what kind of institution engages in them. These regulatory activities are not mutually exclusive (Jickling and Murphy 2010). With respect to Private plaintiffs, Panel D shows the three major plaintiff groups investors, consumers, and shareholders. All three groups often bring class action lawsuits, while institutional investors frequently also bring single-plaintiff lawsuits. Besides US regulators, national agencies in Europe as well as organs of the European Union also initiate enforcement actions against banks. The major European regulators are listed in Panel E.

\begin{tabular}{l} 
Law enforcer $\quad$ Description \\
\hline Panel A: General law enforcement
\end{tabular}

Panel $A \cdot$ General law enforcement

Department of Justice The US Department of Justice is a federal executive department of the US, responsible for the (DOJ) enforcement of the federal law. It handles all criminal prosecutions and civil suits in which the United States has an interest. The Justice Department's most important law enforcement agency, which handles the investigations of crimes and wrongdoings, is the Federal Bureau of Investigations (FBI).

Enforcement of: Antitrust, financial fraud, consumer fraud, financial crimes.

State Departments of Justice (State DOJ)
The State Department of Justice is the executive department of the state, responsible for the enforcement of state law. It assumes jurisdiction only when state law is concerned and handles all criminal prosecutions and civil suits in which the the state has an interest.

Enforcement of: Financial fraud, consumer fraud, financial crimes.

Panel B: Financial institution regulators

The Federal Reserve (Fed)

Office of the Comptroller of the Currency (OCC)

Federal Deposit Insurance Corporation (FDIC)

Federal Housing Finance Agency (FHFA)
The Federal Reserve System is the central bank of the US and thereby manages the nations money supply, interest rates, and serves as the banks' lender of last resort. It also oversees and regulates commercial banks. The Fed consists, amongst others, of the presidentially appointed Board of Governors and 12 regional reserve banks. Supervised lending institutions are, for example, bank holding companies, US branches of foreign banks, and state-chartered banks that are members of the federal reserve system. Following the Dodd-Frank Act, the Fed became the primary regulator of all financial firms that are deemed to be systemically important by the Financial Stability Oversight Council (FSOC). The Fed has safety and soundness authority over payment, clearing, and settlement systems of these firms.

Regulation of: Safety and soundness, systematic risk.

The Office of the Comptroller of the Currency is part of the Department of the Treasury and regulates a wide variety of financial functions of federally chartered banks. It also oversees systemic risk among nationally chartered banks. The OCC is able to issue cease and desist orders and revoke federal bank charters and, following Dodd-Frank Act, the OCC is the primary regulator for federally chartered thrift institutions. Until then this was the task of the Office of Thrift Supervision (OTS), which was, however, abolished by the Dodd-Frank Act. Regulation of: Safety and soundness, systematic risk.

The Federal Deposit Insurance Corporation is an independent agency of the US that provides deposit insurance for its member banks' depositors. Since the Dodd-Frank Act, deposits of up to 250,000 US dollars are insured. The FDIC also has regulatory jurisdiction over its member institutions. This translates into broad regulatory power, since nearly all banks carry FDIC deposit insurance. Furthermore, the FDIC is the primary supervising agency of state banks that are not members of the Federal Reserve System and state-chartered thrift institutions. Regulation of: Safety and soundness.

The Federal Housing Finance Agency is an independent agency of the United States. It regulates the housing finance-related government-sponsored enterprises (GSE) Federal National Mortgage Association (FNMA, or Fannie Mae), Federal Home Loan Mortgage Corporation (FHLMC, or Freddie Mac) and the Federal Home Loan Banks. It was created by the Housing and Economic Recovery Act of 2008 specifically due to concerns about risk arising from the rapid growth of Fannie Mae and Freddie Mac. The FHFA was given enhanced powers to ensure safety and soundness of its regulated institutions. Since September 2008 the FHFA is acting as the conservator for Fannie Mae and Freddie Mac. Besides its regulatory tasks, the FHFA also files lawsuits on behalf of both GSEs against other banks.

Regulation of: Safety and soundness. 
Table I (continued): Major US and European regulators and law enforcers.

\begin{tabular}{ll}
\hline Law enforcer & Description \\
\hline New York State & The New York State Department of Financial Services is an executive department of the New York \\
Department of & state government created in 2011 by consolidation of the New York State Insurance Department \\
Financial Services & and New York State Banking Department. The DFS supervises all banks, credit unions and other \\
(DFS) & financial institutions that are New York State-chartered or licensed and monitors the continued \\
& solvency, safety, soundness and prudent conduct of these financial institutions. \\
& Regulation of: Safety and soundness, consumer protection.
\end{tabular}

Panel C: Financial market regulators

Securities and Exchange Commission (SEC)

Commodities and Futures Trading Commission (CFTC)

Financial Industry Regulatory Authority (FINRA)

Bureau of Consumer Financial Protection (CFBP)
The Securities and Exchange Commission is an independent federal agency that enforces security laws, supervises security markets and the security exchange on these markets. It is tasked with keeping markets transparent and protect investors from fraud. Since there is no governmental guarantee for securities investors comparable to the deposit insurance of the FDIC, the SEC is ensures that risks are fairly disclosed to investors. Thereby investors shall be enabled to make informed investment decisions. Generally, the SEC supervises all firms that sell securities to the public and security market intermediaries. These are mainly brokerage firms and dealers, clearing agencies, mutual funds, and investment advisers. Unlike banking regulators, the SEC can only act if a firm directly violates disclosure requirements or certain other rules but has no authority to directly intervene in a financial firm's business when a firm engages in risky and unsafe practices. Regulation of: Disclosure requirements, investor protection against fraud.

The Commodities and Futures Trading Commission is an independent agency of the US government that regulates the futures, options, and swaps markets related to derivatives and other products that are subject to the Commodity Exchange Act (CEA). Similar to the SEC the CFTC's mission is to keep markets transparent and protect investors from fraud. The CFTC supervises futures exchanges, brokers, commodity pool operators, and trading advisors. Following the passage of the Dodd-Frank Act, the CFTC now also supervises swap dealers, major swap participants, and swap execution facilities.

Regulation of: Investor protection against excessive speculation, price manipulation, and fraud.

The Financial Industry Regulatory Authority, Inc., is a self-regulatory organization (SRO) and thereby the largest non-governmental regulatory organization for securities brokers and dealers doing business in the US. FINRA regulates trading in equities, corporate bonds, securities futures, and options. The primary regulator of the securities industry is the SEC. However, the SEC delegates some of its regulatory duties to the FINRA, which was created in 2007 through the consolidation of National Association Of Securities Dealers (NASD) and the member regulation, enforcement and arbitration operations of the New York Stock Exchange (NYSE). Like the SEC the general task of the FINRA is to protect investors. All firms dealing in securities that are not regulated by another SRO are required to be member firms of and are thereby regulated by the FINRA.

Regulation of: Licensing, investor protection.

The Bureau of Consumer Financial Protection is an independent federal agency and is funded by the Federal Reserve. It was established following the Dodd-Frank Act in 2010. The CFBP serves as the primary federal enforcer of consumer protection laws and has jurisdiction over many financial institutions that offer these services.

Regulation of: Consumer protection.

Panel D: Private plaintiffs

Investors $\quad$ Many lawsuits against banks are single-plaintiff lawsuits filed by firms or class actions filed by classes of institutional investors like mutual and hedge funds combating the misrepresentation of financial products and market manipulations.

Enforcement of: Misrepresentation, market manipulation.

Consumers \& Clients

Defrauded consumers and clients often bring lawsuits to banks. Consumer lawsuits are consolidated into class actions with a large number of class members. Examples of consumer fraud are excessive overdraft fees and fraudulent marketing practices. Examples of clients fraud are antitrust violations.

Enforcement of: Consumer fraud, antitrust.

Shareholders
If a corporation commits a material misstatement or omits relevant facts in its communication with the public, its shareholders may not be given all relevant information to assess the corporation's true value and thereby make an informed investment decision. Under these circumstances shareholders may privately sue the corporation alleging that they have bought the firm's stock at an inflated price. Shareholder class action lawsuits are generally considered a necessary supplement to the SEC's enforcement actions.

Enforcement of: Shareholder fraud. 
Table I (continued): Major US and European regulators and law enforcers.

\begin{tabular}{|c|c|}
\hline Law enforcer & Description \\
\hline \multicolumn{2}{|c|}{ Panel E: European authorities } \\
\hline $\begin{array}{l}\text { Financial Conduct } \\
\text { Authority (FCA) }\end{array}$ & $\begin{array}{l}\text { The Financial Conduct Authority is an independent authority of the United Kingdom, regulating } \\
\text { financial institutions doing business in the UK. Following the Financial Services Act of } 2012 \text { the } \\
\text { FCA was established in } 2013 \text { together with the Prudential Regulation Authority (PRA) as the two } \\
\text { successors of the Financial Services Authority (FSA). The FCA is the primary enforcer of } \\
\text { consumer protection in the UK. } \\
\text { Enforcement of: Consumer protection. }\end{array}$ \\
\hline European Commission & $\begin{array}{l}\text { The European Commission is the executive branch of the European Union and is divided into } \\
\text { Portfolios. The Competition Portfolio is headed by the Commissioner for Competition. It has the } \\
\text { responsibility for the enforcement of European antitrust law. The European Commission and the } \\
\text { national competition authorities in all EU Member States cooperate with each other through the } \\
\text { European Competition Network (ECN). } \\
\text { Enforcement of: Antitrust. }\end{array}$ \\
\hline $\begin{array}{l}\text { Swiss Financial } \\
\text { Market Supervisory } \\
\text { Authority (FINMA) }\end{array}$ & $\begin{array}{l}\text { The Swiss Financial Market Supervisory Authority is the main Swiss agency for financial } \\
\text { regulation. Its main task is the protection of investors and to ensure the functioning of the Swiss } \\
\text { financial market. It therefore licenses and supervises financial institutions for the safety and } \\
\text { soundness. It was established in } 2007 \text { by combining multiple preceding agencies into one single } \\
\text { body that is responsible for all financial regulation in Switzerland. A major part of the FINMA's } \\
\text { duty is two regulate the two Swiss global financial institutions, UBS and Credit Suisse, but it } \\
\text { regulates and has the power to fine all financial institutions operating in Switzerland. } \\
\text { Regulation of: Licensing, investor protection, money laundering. }\end{array}$ \\
\hline
\end{tabular}


Table II: Characteristics of bank litigation.

This table shows the characteristics of our database as well as several subsamples. The sum, mean, median, minimum, and maximum of the total monetary penalty (TMP), which represents the total amount of all monetary penalties connected to the resolution announcement, and of the relative monetary penalty (RMP), which represents the TMP relative to the bank's market value six months prior to the resolution announcement, are shown. The sum of the RMP is calculated as the sum of total monetary penalties paid relative to the respective banks' market values at the end of 2004. Additionally, the number of resolutions are given for every subsample. Panel A shows the characteristics of the total database of 409 cases. Panel B splits the database according to the defendant bank and is sorted according to the sum of TMPs. In parentheses the nationality of the respective bank's head quarter is given. In Panel $\mathrm{C}$ the database is divided according to the nature of the misconduct, Panel D splits the sample according to the plaintiff or regulator nationality, and Panel E splits the sample according to bank nationality, more specifically the location of its head quarter, and again sorted according to the sum of TMP. Panels F, G, and $\mathrm{H}$ split the sample according to years for all plaintiffs, for US plaintiffs, and for European plaintiffs.

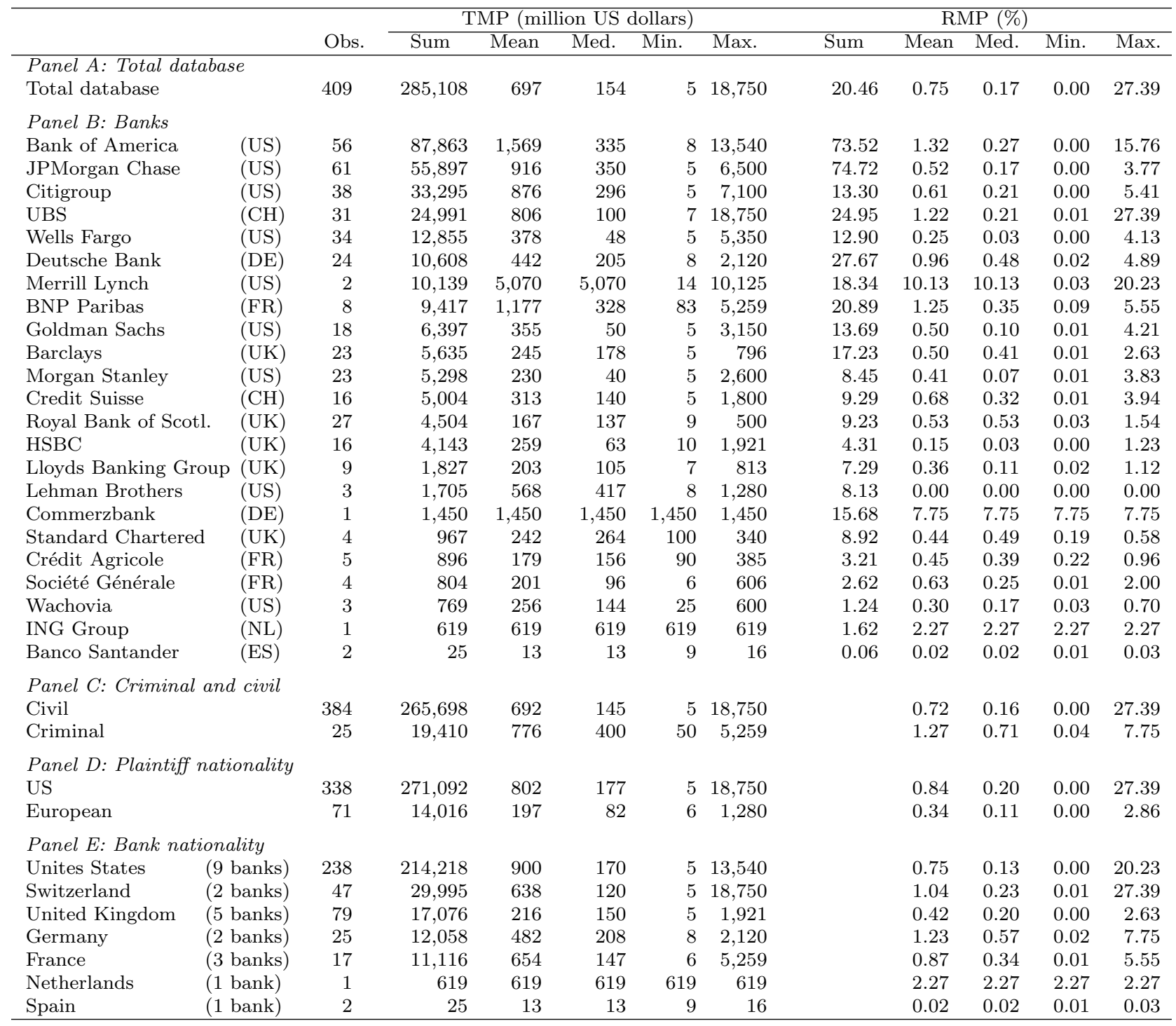


Table II (continued): Characteristics of bank litigation.

\begin{tabular}{|c|c|c|c|c|c|c|c|c|c|c|c|}
\hline & \multirow[b]{2}{*}{ Obs. } & \multicolumn{5}{|c|}{ TMP (million US dollars) } & \multicolumn{5}{|c|}{ RMP (\%) } \\
\hline & & Sum & Mean & Med. & Min. & Max. & Sum & Mean & Med. & Min. & Max. \\
\hline \multicolumn{12}{|c|}{ Panel F: Years } \\
\hline 2005 & 14 & 7,235 & 517 & 40 & 6 & 2,200 & & 0.34 & 0.08 & 0.01 & 1.58 \\
\hline 2006 & 10 & 1,397 & 140 & 34 & 10 & 600 & & 0.17 & 0.04 & 0.02 & 0.70 \\
\hline 2007 & 8 & 689 & 86 & 14 & 6 & 441 & & 0.10 & 0.01 & 0.01 & 0.57 \\
\hline 2008 & 15 & 53,815 & 3,588 & 282 & 6 & 18,750 & & 4.37 & 0.30 & 0.01 & 27.39 \\
\hline 2009 & 11 & 3,303 & 300 & 217 & 7 & 780 & & 0.49 & 0.35 & 0.03 & 1.28 \\
\hline 2010 & 31 & 6,081 & 196 & 75 & 7 & 2,034 & & 0.25 & 0.08 & 0.01 & 1.59 \\
\hline 2011 & 39 & 18,927 & 485 & 85 & 8 & 8,500 & & 0.37 & 0.05 & 0.00 & 5.92 \\
\hline 2012 & 58 & 38,714 & 667 & 105 & 5 & 11,820 & & 0.84 & 0.19 & 0.00 & 15.76 \\
\hline 2013 & 70 & 64,774 & 925 & 316 & 9 & 10,300 & & 0.86 & 0.33 & 0.01 & 12.22 \\
\hline 2014 & 84 & 68,392 & 814 & 285 & 5 & 13,540 & & 0.75 & 0.22 & 0.00 & 7.85 \\
\hline 2015 & 69 & 21,782 & 316 & 164 & 7 & 2,600 & & 0.51 & 0.20 & 0.00 & 7.75 \\
\hline \multicolumn{12}{|c|}{ Panel G: Years for US plaintiffs } \\
\hline 2005 & 12 & 7,027 & 586 & 40 & 6 & 2,200 & & 0.37 & 0.08 & 0.01 & 1.58 \\
\hline 2006 & 9 & 1,386 & 154 & 43 & 10 & 600 & & 0.18 & 0.05 & 0.02 & 0.70 \\
\hline 2007 & 7 & 542 & 77 & 13 & 6 & 441 & & 0.10 & 0.01 & 0.01 & 0.57 \\
\hline 2008 & 11 & 53,344 & 4,849 & 1,523 & 18 & 18,750 & & 5.91 & 2.19 & 0.02 & 27.39 \\
\hline 2009 & 10 & 3,220 & 322 & 284 & 7 & 780 & & 0.52 & 0.45 & 0.03 & 1.28 \\
\hline 2010 & 23 & 5,680 & 247 & 101 & 7 & 2,034 & & 0.31 & 0.08 & 0.01 & 1.59 \\
\hline 2011 & 31 & 17,597 & 568 & 88 & 8 & 8,500 & & 0.41 & 0.05 & 0.00 & 5.92 \\
\hline 2012 & 50 & 37,420 & 748 & 129 & 5 & 11,820 & & 0.89 & 0.19 & 0.00 & 15.76 \\
\hline 2013 & 56 & 61,742 & 1,103 & 374 & 10 & 10,300 & & 0.95 & 0.38 & 0.01 & 12.22 \\
\hline 2014 & 65 & 63,477 & 977 & 290 & 5 & 13,540 & & 0.84 & 0.26 & 0.00 & 7.85 \\
\hline 2015 & 64 & 19,658 & 307 & 162 & 7 & 2,600 & & 0.53 & 0.20 & 0.01 & 7.75 \\
\hline \multicolumn{12}{|c|}{ Panel H: Years for European plaintiffs } \\
\hline 2005 & 2 & 208 & 104 & 104 & 21 & 187 & & 0.16 & 0.16 & 0.01 & 0.31 \\
\hline 2006 & 1 & 11 & 11 & 11 & 11 & 11 & & 0.02 & 0.02 & 0.02 & 0.02 \\
\hline 2007 & 1 & 147 & 147 & 147 & 147 & 147 & & 0.16 & 0.16 & 0.16 & 0.16 \\
\hline 2008 & 4 & 471 & 118 & 91 & 6 & 282 & & 0.15 & 0.14 & 0.01 & 0.30 \\
\hline 2009 & 1 & 82 & 82 & 82 & 82 & 82 & & 0.21 & 0.21 & 0.21 & 0.21 \\
\hline 2010 & 8 & 401 & 50 & 46 & 9 & 108 & & 0.09 & 0.06 & 0.01 & 0.27 \\
\hline 2011 & 8 & 1,330 & 166 & 63 & 10 & 813 & & 0.23 & 0.03 & 0.02 & 1.12 \\
\hline 2012 & 8 & 1,294 & 162 & 56 & 7 & 796 & & 0.48 & 0.13 & 0.02 & 2.63 \\
\hline 2013 & 14 & 3,031 & 217 & 158 & 9 & 633 & & 0.50 & 0.13 & 0.02 & 2.00 \\
\hline 2014 & 19 & 4,915 & 259 & 138 & 8 & 1,270 & & 0.42 & 0.17 & 0.01 & 2.86 \\
\hline 2015 & 5 & 2,124 & 425 & 340 & 20 & 1,280 & & 0.31 & 0.02 & 0.00 & 0.78 \\
\hline
\end{tabular}


Table III: Sample selection procedure.

This table shows the sample selection procedure for the empirical analysis. Redundant cases are cases where a bank resolves at least two cases on a single day. Multiple cases summarizes all redundant cases of a bank during a specific day in order to form a synthetic new case, representing all single cases of that day. Insufficient stock data and Insufficient bond data refer to cases where a bank was no longer stock-listed or had unavailable or illiquid bond quotes, respectively. Confounding events are cases where an unrelated event took place during the two days preceding or following the announcement. These events are then shown in more detail in the lines below and relate to confounding events, such as earning announcements, M\&A or SEO announcements, rating changes, etc. The last line shows the sample for the empirical analysis, which results from the total database after accounting for the cases not suited for the empirical analysis.

\begin{tabular}{|c|c|c|c|c|}
\hline & \multirow[b]{2}{*}{ Observations } & \multicolumn{3}{|c|}{ Total monetary penalty (million US dollars) } \\
\hline & & Sum & Mean & Median \\
\hline Database & 409 & 285,108 & 697 & 154 \\
\hline - Redundant cases & 101 & 88,521 & 876 & 310 \\
\hline + Multiple cases & 37 & 88,521 & 2,384 & 668 \\
\hline - Insufficient stock data & 3 & 1,705 & 568 & 417 \\
\hline - Insufficient bond data & 29 & 17,124 & 590 & 173 \\
\hline - Confounding events & 62 & 43,908 & 708 & 148 \\
\hline Earnings & 21 & 9,996 & 476 & 330 \\
\hline$M E A$ or $S E O$ & 12 & 10,080 & 840 & 37 \\
\hline Other major event & 6 & 869 & 145 & 86 \\
\hline Rating change & 5 & 15,358 & 3,072 & 150 \\
\hline Personnel change & 5 & 1,247 & 249 & 145 \\
\hline Legal penalty & 4 & 919 & 230 & 79 \\
\hline Regulatory event & 3 & 1,030 & 343 & 217 \\
\hline Layoffs & 2 & 2,460 & 1,230 & 1,230 \\
\hline Provision or writeoff & 2 & 282 & 141 & 141 \\
\hline Legal investigation & 2 & 1,669 & 834 & 835 \\
\hline Sample for empirical analysis & 251 & 222,069 & 885 & 137 \\
\hline
\end{tabular}

Table IV: Sample description.

This table shows the number of observations (N), mean, median, standard deviation, minimum, 25th percentile, 75 th percentile, and the maximum of several variables used in the empirical analysis. $l g$ (Assets) is equal to the common logarithm of the bank's total assets in million US dollars at the end of the year prior to the settlement. The variable Volatility accounts for the recent six-month stock volatility. The variable Volatility accounts for the recent six-month stock volatility. The variable Cash flow measures the size of a bank's cash flows divided by its market value, Net income measures its profitability through the ratio of a bank's net income divided by its market value, and Debt-to-capital measures a bank's leverage through its ratio of debt to capital. All three variables relate to the end of the year prior to the event. TMP represents the total monetary size of the settlement in million US dollars and the relative monetary penalty $(R M P)$ represents the TMP divided by the bank's market value six month prior to the settlement. Multiple is a binary variable which equals one if more than one settlement for that bank is announced at the same time, and zero otherwise. The variable Crime is equal to one if a criminal prosecution is settled, and zero otherwise. $U S$ is a binary variable that is equal to one if a plaintiff or regulator is from the US, and zero otherwise. The variable Crisis is equal to one in case the resolution announcement lies between 2007 and 2011, and zero otherwise.

\begin{tabular}{|c|c|c|c|c|c|c|c|c|}
\hline & $\mathrm{N}$ & Mean & Median & Std. dev. & Min. & 25 th perc. & 75th perc. & Max. \\
\hline $\lg ($ Assets $)$ & 251 & 7.31 & 7.36 & 0.39 & 5.95 & 7.02 & 7.66 & 7.85 \\
\hline Volatility (\%) & 251 & 1.76 & 1.53 & 0.94 & 0.75 & 1.21 & 2.06 & 9.69 \\
\hline Cash flow (\%) & 251 & 19.80 & 16.59 & 16.60 & -58.76 & 11.66 & 24.50 & 106.24 \\
\hline Net income (\%) & 251 & 5.84 & 8.04 & 11.78 & -49.96 & 4.13 & 10.68 & 35.87 \\
\hline Debt-to-capital (\%) & 251 & 76.11 & 76.76 & 9.44 & 53.73 & 70.11 & 83.28 & 95.32 \\
\hline TMP (mio. US-\$) & 251 & 884.74 & 137.00 & $2,355.65$ & 5.00 & 26.00 & 591.00 & $18,750.00$ \\
\hline $\operatorname{RMP}(\%)$ & 251 & 0.88 & 0.15 & 2.43 & 0.00 & 0.03 & 0.60 & 27.39 \\
\hline Multiple & 251 & 0.11 & 0.00 & 0.32 & 0.00 & 0.00 & 0.00 & 1.00 \\
\hline Crime & 251 & 0.06 & 0.00 & 0.24 & 0.00 & 0.00 & 0.00 & 1.00 \\
\hline US & 251 & 0.82 & 1.00 & 0.38 & 0.00 & 1.00 & 1.00 & 1.00 \\
\hline
\end{tabular}


Table V: Stock event study results.

This table shows the results of the stock event study. Daily abnormal returns are calculated using a market model event study, the value-weighted Datastream domestic index as the benchmark index, and a 252-day estimation period ending 11 days prior to the event day. In order to examine short-term wealth effects, the average abnormal returns on days $t=-1, t=0$, and $t=+1$, are calculated, as well as the average cumulative abnormal returns (ACARs) during the asymmetric short-term event windows $[-1 ; 0]$ and $[0 ;+1]$ to capture anticipated and lagged price adjustments. As parametric test statistics, the $t$-test and the variance-change corrected standardized cross-section test introduced by Boehmer et al. (1991), the BMP-test are used. Furthermore, significance is also tested using the nonparametric the Wilcoxon signed rank test and the nonparametric rank test first introduced by Corrado (1989) and later refined by Corrado and Zivney (1992), the CZ-test. ${ }^{*},{ }^{* *},{ }^{* * *}$ denote statistical significance at the $10 \%, 5 \%$, and $1 \%$ level, respectively.

\begin{tabular}{lccccccc}
\hline & Observations & $\begin{array}{c}\text { ACAR } \\
(\%)\end{array}$ & $\begin{array}{c}\text { Median CAR } \\
(\%)\end{array}$ & $\begin{array}{c}t \text {-test } \\
(t \text {-value })\end{array}$ & $\begin{array}{c}\text { BMP-test } \\
(t \text {-value })\end{array}$ & $\begin{array}{c}\text { Wilcoxon } \\
(Z \text {-score })\end{array}$ & $\begin{array}{c}\text { CZ-test } \\
(Z \text {-score })\end{array}$ \\
\hline$[-1 ;-1]$ & 251 & 0.04 & -0.05 & 0.62 & 0.56 & 0.14 & 0.39 \\
{$[0 ; 0]$} & 251 & 0.30 & 0.10 & $3.54^{* * *}$ & $3.17^{* * *}$ & $2.26^{* *}$ & $2.05^{* *}$ \\
{$[+1 ;+1]$} & 251 & 0.01 & -0.10 & 0.18 & -0.05 & 1.26 & -0.63 \\
{$[-1 ; 0]$} & 251 & 0.34 & 0.08 & $3.23^{* * *}$ & $2.86^{* * *}$ & $2.27^{* *}$ & $1.73^{*}$ \\
{$[0 ;+1]$} & 251 & 0.31 & 0.02 & $2.79^{* * *}$ & $2.37^{* *}$ & 1.15 & 1.00 \\
\hline
\end{tabular}

Table VI: Bond event study results.

This table shows the results of the bond event study. Expected bond returns are calculated using the matching portfolio model. The bonds are allocated to the portfolios according to three term to maturity classes and six rating classes. To condense the abnormal bond returns of all bonds a certain bank has outstanding into one abnormal bond return, the value-weighted firm level approach is used. In order to examine short-term wealth effects, the average abnormal bond returns on days $t=-1, t=0$, and $t=+1$ are calculated, as well as the average cumulative abnormal bond returns $(A C A B R s)$ during the asymmetric short-term event windows $[-1 ; 0]$ and $[0 ;+1]$ to capture anticipated and lagged price adjustments. To evaluate the statistical significance of the abnormal returns, the parametric standardized and unstandardized $t$-tests and nonparametric Wilcoxon signed rank tests are used. Abnormal bond returns are standardized with their estimated standard deviation during the time frame $[-10 ;+10]$, excluding the short-term window $[-1 ;+1] .{ }^{*},{ }^{* *},{ }^{* *}$ denote statistical significance at the $10 \%, 5 \%$, and $1 \%$ level, respectively.

\begin{tabular}{|c|c|c|c|c|c|c|c|}
\hline & Observations & $\begin{array}{l}\text { ACABR } \\
\text { (bps) }\end{array}$ & $\begin{array}{l}\text { Median CABR } \\
\text { (bps) }\end{array}$ & $\begin{array}{c}t \text {-test } \\
(t \text {-value })\end{array}$ & $\begin{array}{l}\text { Wilcoxon } \\
(Z \text {-score })\end{array}$ & $\begin{array}{l}\text { Std. } t \text {-test } \\
(t \text {-value })\end{array}$ & $\begin{array}{l}\text { Std. Wilcoxon } \\
(Z \text {-score })\end{array}$ \\
\hline$[-1 ;-1]$ & 251 & -0.87 & -0.75 & -1.20 & -1.31 & -1.20 & -1.42 \\
\hline$[0 ; 0]$ & 251 & 0.58 & 0.47 & 0.71 & 1.14 & 1.11 & 1.06 \\
\hline$[+1 ;+1]$ & 251 & 1.78 & 0.94 & $2.03^{* *}$ & $2.16^{* *}$ & $2.22^{* *}$ & $2.07^{* *}$ \\
\hline$[-1 ; 0]$ & 251 & -0.29 & -0.88 & -0.26 & -0.02 & 0.03 & -0.36 \\
\hline$[0 ;+1]$ & 251 & 2.36 & 2.07 & $2.09 * *$ & $2.37^{* *}$ & $2.30 * *$ & $2.33^{* *}$ \\
\hline
\end{tabular}


Table VII: Determinants of banks' stock and bond abnormal returns.

This table shows the coefficients and robust $t$-statistics (in parentheses) obtained through an ordinary least squares estimation using the average abnormal return of the event day $A R_{0}$ and the cumulative abnormal bond return $C A B R_{[0 ;+1]}$ as the dependent variable. Model I uses only company-specific variables, Model II only case-specific variables, and Model III company- and casespecific variables. The company-specific variables include the variable $l g$ (Assets) which is equal to the common logarithm of the bank's total assets in million US dollars at the end of the year prior to the settlement. The variable Volatility accounts for the recent six-month stock or bond volatility, respectively. The variable Volatility accounts for the recent six-month stock volatility. The variable Cash flow measures the size of a bank's cash flows divided by its market value, Net income measures its profitability through the ratio of a bank's net income divided by its market value, and Debt-to-capital measures a bank's leverage through its ratio of debt to capital. All three variables relate to the end of the year prior to the event. The case-specific variables include $R M P$, the relative monetary penalty, which represents the sum of all settlement-related monetary penalties divided by the bank's market value six month prior to the settlement. Multiple is a binary variable which equals one if more than one settlement is announced at the same time, and zero otherwise. The variable Crime is equal to one if a criminal prosecution is settled, and zero otherwise. $U S$ is an additional binary variable that is equal to one if a plaintiff or regulator is from the US, and zero otherwise. The binary variable Financial crisis is equal to one in case the resolution announcement lies between 2007 and 2011. Sovereign debt crisis is likewise a binary variable equal to one for Euro-zone banks from 2012 and 2013 , and zero otherwise. ${ }^{*},{ }^{* *},{ }^{* *}$ denote statistical significance at the $10 \%, 5 \%$, and $1 \%$ level, respectively.

\begin{tabular}{|c|c|c|c|c|c|c|}
\hline & \multicolumn{3}{|c|}{$\mathrm{AR}_{0}$} & \multicolumn{3}{|c|}{$\mathrm{CABR}_{[0 ;+1]}$} \\
\hline & $\mathrm{I}$ & II & III & $\mathrm{I}$ & II & III \\
\hline Company-specific & & & & & & \\
\hline $\lg$ (Assets) & $\begin{array}{c}-0.50^{*} \\
(-1.71)\end{array}$ & & $\begin{array}{c}-0.61^{*} \\
(-1.95)\end{array}$ & $\begin{array}{c}-4.73 \\
(-1.08)\end{array}$ & & $\begin{array}{c}-3.72 \\
(-1.01)\end{array}$ \\
\hline Volatility & $\begin{array}{l}0.36^{* * *} \\
(3.89)\end{array}$ & & $\begin{array}{l}0.31^{* * *} \\
(3.85)\end{array}$ & $\begin{array}{c}2.48^{*} \\
(1.89)\end{array}$ & & $\begin{array}{r}2.86^{*} \\
(1.90)\end{array}$ \\
\hline Cash flow & $\begin{array}{c}0.01 \\
(1.49)\end{array}$ & & $\begin{array}{c}0.01^{*} \\
(1.65)\end{array}$ & $\begin{array}{c}0.03 \\
(0.22)\end{array}$ & & $\begin{array}{c}0.03 \\
(0.24)\end{array}$ \\
\hline Net income & $\begin{array}{c}0.00 \\
(0.38)\end{array}$ & & $\begin{array}{c}0.00 \\
(0.35)\end{array}$ & $\begin{array}{c}-0.10 \\
(-0.78)\end{array}$ & & $\begin{array}{l}-0.06 \\
(-0.45)\end{array}$ \\
\hline Debt-to-capital & $\begin{array}{c}0.00 \\
(-0.14)\end{array}$ & & $\begin{array}{c}0.00 \\
(-0.14)\end{array}$ & $\begin{array}{c}0.09 \\
(0.80)\end{array}$ & & $\begin{array}{c}0.07 \\
(0.48)\end{array}$ \\
\hline Case-specific & & & & & & \\
\hline $\mathrm{RMP}$ & & $\begin{array}{l}0.17^{* * *} \\
(5.26)\end{array}$ & $\begin{array}{l}0.16^{* * *} \\
(5.26)\end{array}$ & & $\begin{array}{c}-0.02 \\
(-0.08)\end{array}$ & $\begin{array}{l}-0.25 \\
(-0.72)\end{array}$ \\
\hline Multiple & & $\begin{array}{l}-0.01 \\
(-0.02)\end{array}$ & $\begin{array}{c}0.20 \\
(0.62)\end{array}$ & & $\begin{array}{c}-3.87^{*} \\
(-1.81)\end{array}$ & $\begin{array}{l}-1.58 \\
(-0.71)\end{array}$ \\
\hline Crime & & $\begin{array}{c}0.03 \\
(0.07)\end{array}$ & $\begin{array}{c}-0.29 \\
(-0.70)\end{array}$ & & $\begin{array}{c}3.39 \\
(1.16)\end{array}$ & $\begin{array}{c}1.55 \\
(0.40)\end{array}$ \\
\hline US & & $\begin{array}{c}0.13 \\
(0.58)\end{array}$ & $\begin{array}{c}0.09 \\
(0.36)\end{array}$ & & $\begin{array}{c}-4.74^{*} \\
(-1.76)\end{array}$ & $\begin{array}{l}-3.65 \\
(-1.37)\end{array}$ \\
\hline Financial crisis & & & $\begin{array}{c}-0.07 \\
(-0.29)\end{array}$ & & & $\begin{array}{l}-0.81 \\
(-0.18)\end{array}$ \\
\hline Sovereign debt crisis & & & $\begin{array}{c}-0.42 \\
(-1.07)\end{array}$ & & & $\begin{array}{c}2.30 \\
(0.26)\end{array}$ \\
\hline Constant & $\begin{array}{c}3.24 \\
(1.28)\end{array}$ & $\begin{array}{c}0.04 \\
(0.20)\end{array}$ & $\begin{array}{c}3.87 \\
(1.46)\end{array}$ & $\begin{array}{l}18.08 \\
(0.62)\end{array}$ & $\begin{array}{l}6.51^{* * *} \\
(2.64)\end{array}$ & $\begin{array}{l}22.68 \\
(0.70)\end{array}$ \\
\hline Observations & 251 & 251 & 251 & 251 & 251 & 251 \\
\hline$R^{2}$ & 0.09 & 0.09 & 0.17 & 0.04 & 0.01 & 0.05 \\
\hline Adjusted $R^{2}$ & 0.07 & 0.08 & 0.13 & 0.018 & 0.00 & 0.01 \\
\hline F-value & $5.22 * * *$ & $7.30 * * *$ & $6.78^{* * *}$ & $2.61^{* *}$ & 1.31 & $1.44^{*}$ \\
\hline
\end{tabular}


Table VIII: CDS event study results.

This table shows the results of the CDS event study. The five-year senior CDS mid-spread in US dollars is used to calculate abnormal CDS spread changes (ASCs) by adjusting actually observed CDS spread changes by the spread change of a matching portfolio of the same rating class as the event firm. The daily CDS portfolios are computed as the equally weighted crosssectional mean of all 211 banks with available CDS data through Reuters EOD and a long-term issuer rating of Moody's, excluding the event firm. In total, six portfolios are constructed representing the six rating categories Aaa-Aa, A, Baa, Ba, B, and below B. In order to examine short-term wealth effects, the average abnormal spread changes on days $t=-1, t=0$, and $t=+1$ are calculated, as well as the average cumulative abnormal spread changes $(A C A S C s)$ during the asymmetric short-term event windows $[-1 ; 0]$ and $[0 ;+1]$ to capture anticipated and lagged price adjustments. Statistical significance is tested using the parametric $t$-test and the nonparametric Wilcoxon signed-rank test. ${ }^{*},{ }^{* *},{ }^{* * *}$ denote statistical significance at the $10 \%, 5 \%$, and $1 \%$ level, respectively.

\begin{tabular}{lccccc}
\hline & ACASC & $\begin{array}{c}\text { Median CASC } \\
(\mathrm{bps})\end{array}$ & $\begin{array}{c}t \text {-test } \\
(t \text {-value })\end{array}$ & $\begin{array}{c}\text { Wilcoxon } \\
(Z \text {-score })\end{array}$ \\
\hline$[-1 ;-1]$ & Observations & $(\mathrm{bps})$ & 0.10 & 0.61 & 1.05 \\
{$[0 ; 0]$} & 251 & 0.13 & -0.11 & $-3.13^{* * *}$ & $-2.26^{* *}$ \\
{$[+1 ;+1]$} & 251 & -0.71 & -0.08 & -0.15 & $-1.72^{*}$ \\
{$[-1 ; 0]$} & 251 & -0.04 & -0.24 & $-2.02^{* *}$ & -1.62 \\
{$[0 ;+1]$} & 251 & -0.58 & -0.27 & $-2.48^{* *}$ & $-2.34^{* *}$ \\
\hline
\end{tabular}


Table IX: Stock, bond, and CDS market interactions around bank settlements.

This table shows the results of a two-stage estimation of simultaneous equations (2SLS) of stock, bond, and CDS markets with event-time and settlement fixed effects (Model I). Model II shows the baseline results of a regression without allowing for interconnection of markets. The $t$-statistics for both models are shown in parentheses and are calculated with standard errors clustered by settlement. The dependent variables $R_{i t}, B R_{i t}$, and $S C_{i t}$ are a bank's stock return, bond return, and CDS spread change for event $i$ at the time $t$. The bond return is calculated as a value-weighted return of all outstanding bonds of a company. $R_{m, i t}, B R_{M P, i t}$, and $S C_{M P, i t}$ correspond to the domestic stock market return, the bond return of a portfolio matched according to bond rating and maturity, and the spread change of a CDS portfolio matched according to credit rating. We consider the same 251 resolution announcements as for the previous analyses and the time dimension spans 273 days, from 262 days prior until 10 days following the resolution announcement. We further include the contemporaneous values $R_{i t}, B R_{i t}$, $S C_{i t}$ as well as the lagged values $R_{i t-1}, B R_{i t-1}$, and $S C_{i t-1}$ in all three regressions. Time fixed effects for the resolution announcement are shown for $t \in\{-1,0,+1\}$. ${ }^{*},{ }^{* *},{ }^{* * *}$ denote statistical significance at the $10 \%, 5 \%$, and $1 \%$ level, respectively.

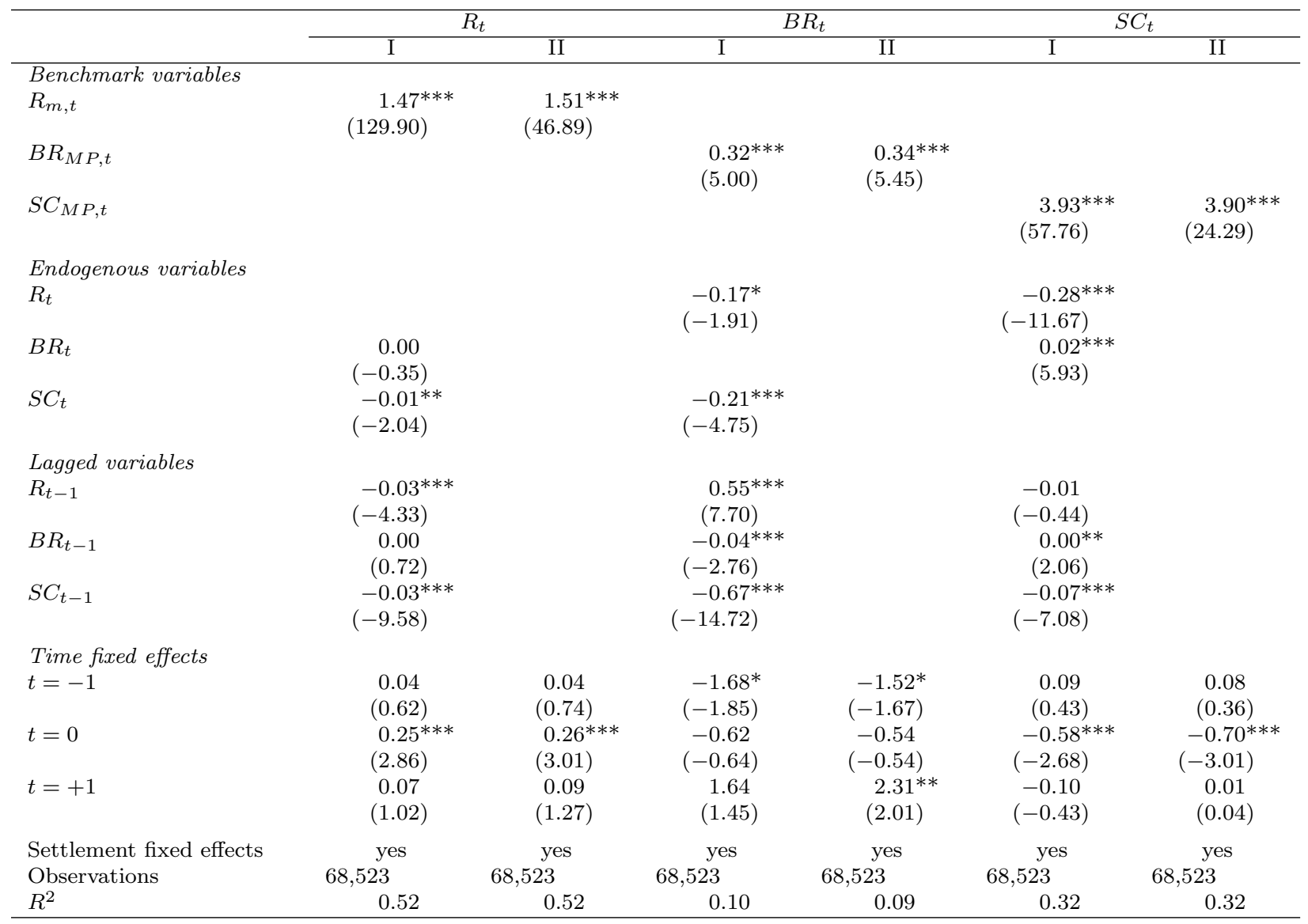


Table X: Event study results for comparable banks.

This table shows the event study results of how penalties imposed on one bank impact comparable financial institutions. Comparable banks are defined as all sample banks that do not announce a resolution on the same day. Daily abnormal returns are calculated using a market model event study, the value-weighted Datastream domestic index as the benchmark, and a 252-day estimation period ending 11 days prior to the event day. In order to examine short-term wealth effects, the average abnormal returns on days $t=-1, t=0$, and $t=+1$, are calculated, as well as the average cumulative abnormal returns (ACARs) during the asymmetric short-term event windows $[-1 ; 0]$ and $[0 ;+1]$ to capture anticipated and lagged price adjustments. As parametric test statistics, the $t$-test and the variance-change corrected standardized cross-section test introduced by Boehmer et al. (1991), the BMP-test are used. Furthermore, significance is also tested using the nonparametric Wilcoxon signed rank test and the nonparametric rank test first introduced by Corrado (1989) and later refined by Corrado and Zivney (1992), the CZ-test. ${ }^{*},{ }^{* *},{ }^{* * *}$ denote statistical significance at the $10 \%, 5 \%$, and $1 \%$ level, respectively.

\begin{tabular}{lccccccrr}
\hline & Observations & $\begin{array}{c}\text { Event } \\
\text { days }\end{array}$ & $\begin{array}{c}\text { ACAR } \\
(\%)\end{array}$ & $\begin{array}{c}\text { Median CAR } \\
(\%)\end{array}$ & $\begin{array}{c}t \text {-test } \\
(t \text {-value })\end{array}$ & $\begin{array}{c}\text { BMP-test } \\
(t \text {-value })\end{array}$ & $\begin{array}{r}\text { Wilcoxon } \\
(Z \text {-score })\end{array}$ & $\begin{array}{r}\text { CZ-test } \\
(Z \text {-score })\end{array}$ \\
\hline$[-1 ;-1]$ & 3,415 & 195 & -0.02 & -0.02 & -0.67 & -0.43 & -1.53 & 0.07 \\
{$[0 ; 0]$} & 3,415 & 195 & 0.07 & -0.02 & $2.63^{* * *}$ & $2.47^{* *}$ & 0.18 & 0.88 \\
{$[+1 ;+1]$} & 3,415 & 195 & 0.03 & -0.02 & 1.11 & 1.03 & -0.61 & 0.52 \\
{$[-1 ; 0]$} & 3,415 & 195 & 0.05 & -0.06 & 1.47 & 1.53 & -0.20 & 0.68 \\
{$[0 ;+1]$} & 3,415 & 195 & 0.09 & 0.01 & $2.63^{* * *}$ & $2.47^{* *}$ & 0.76 & 0.99 \\
\hline
\end{tabular}


Table XI: Determinants of comparable banks' abnormal returns.

This table shows the coefficients and robust $t$-statistics (in parentheses) obtained through an ordinary least squares estimation using the average abnormal return of the comparable bank on the event day $A R_{0}$ as the dependent variable. Model I uses only company-specific variables, Model II only case-specific variables, and Model III company- and case-specific variables as determinants. The company-specific variables include the variable $l g$ (Assets) which is equal to the common logarithm of the bank's total assets in million US dollars at the end of the year prior to the settlement. The variable Volatility accounts for the recent six-month stock volatility. The variable Cash flow measures the size of a bank's cash flows divided by its market value, Net income measures its profitability through the ratio of a bank's net income divided by its market value, and Debt-to-capital measures a bank's leverage through its ratio of debt to capital. All three variables relate to the end of the year prior to the event. The case-specific variables include Informational spillover which is a binary variable that takes the value of one if the comparable bank has a another settlement with the same plaintiff during two years following the settlement of the sued bank, and zero otherwise. $R M P$, the relative monetary penalty which represents the sum of all settlement-related monetary penalties divided by the bank's market value six month prior to the settlement. Multiple is a binary variable which equals one if more than one settlement is announced at the same time, and zero otherwise. The variable Crime is equal to one if a criminal prosecution is settled, and zero otherwise. $U S$ is an additional binary variable that is equal to one if a plaintiff or regulator is from the US, and zero otherwise. The binary variable Financial crisis is equal to one in case the resolution announcement lies between 2007 and 2011. Sovereign debt crisis is likewise a binary variable equal to one for Euro-zone banks from 2012 and 2013 , and zero otherwise. ${ }^{* * *},{ }^{* * *}$ denote statistical significance at the $10 \%, 5 \%$, and $1 \%$ level, respectively.

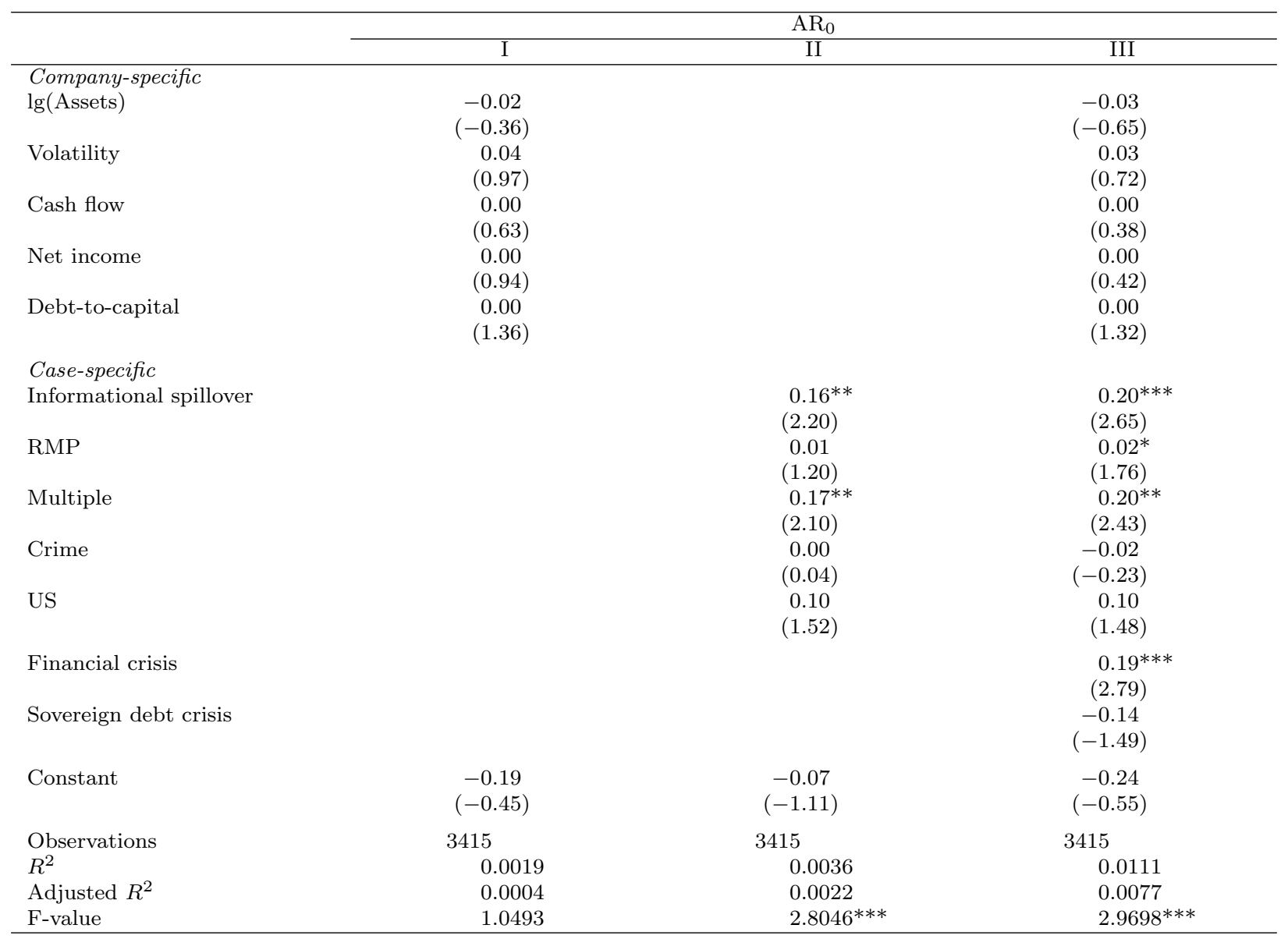


Table XII: Settlements and banks' financial statements.

This table shows the estimated coefficients and $t$-statistics (in parentheses) of regressions on Cash flowit which represents bank $i$ 's operating cash flow divided by its market value at the end of year $t, N_{\text {et }}$ income $_{i t}$ which represents bank $i$ 's net income divided by its market value at the end of year $t$, Tier 1 ratio it which represents bank $i$ 's ratio of tier 1 capital to its risk-weighted assets at the end of year $t$, and Loan growth $i t$ which represents bank $i$ 's growth rate in total loans from year $t$ over year $t-1$. The standard errors used to calculate the $t$-statistics (in parentheses) are clustered by bank. We estimate two regression models. Model I includes year fixed effects and Model II includes year as well as bank fixed effects. The explanatory variables $R M P_{i t}$, Revenue $_{i t}$, and Cash $_{i t}$ relate to bank $i$ 's total monetary penalties paid during year $t$, its revenue, and cash at the end of year $t$, all divided by bank $i$ 's market value at the end of year $t$. $\lg \left(\right.$ Assets $\left._{i t}\right)$ relates to bank $i$ 's common logarithm of total assets at the end of year $t$. Debt-to-capital ${ }_{i t}$ is bank $i$ 's ratio of total debt and total capital at the end of year $t$, and Market-to-book $k_{i t}$ is bank $i$ 's market value divided by its book equity value at the end of year $t .{ }^{*},{ }^{* *},{ }^{* * *}$ denote statistical significance at the $10 \%$, $5 \%$, and $1 \%$ level, respectively.

\begin{tabular}{lcccccccc}
\hline & \multicolumn{2}{c}{ Cash flow } & \multicolumn{2}{c}{ Net income } & \multicolumn{2}{c}{ Tier 1 ratio } & \multicolumn{3}{c}{ Loan growth } \\
\cline { 2 - 9 } & I & II & I & II & I & II & I & II \\
\hline RMP & $-1.18^{* *}$ & $-1.04^{*}$ & -0.49 & -0.27 & -0.01 & -0.02 & -0.34 & -0.36 \\
& $(-2.13)$ & $(-1.72)$ & $(-1.42)$ & $(-1.05)$ & $(-0.20)$ & $(-0.77)$ & $(-0.15)$ & $(-0.14)$ \\
$\lg$ (Assets) & $0.11^{* * *}$ & 0.09 & 0.01 & 0.02 & 0.00 & 0.00 & -0.02 & -0.54 \\
& $(2.81)$ & $(1.01)$ & $(0.51)$ & $(0.46)$ & $(0.59)$ & $(-0.46)$ & $(-0.09)$ & $(-1.25)$ \\
Revenue & $0.05^{*}$ & 0.05 & $-0.04^{* * *}$ & -0.03 & $-0.01^{* * *}$ & 0.00 & -0.06 & 0.14 \\
& $(1.71)$ & $(1.36)$ & $(-2.74)$ & $(-1.60)$ & $(-4.50)$ & $(-1.42)$ & $(-0.46)$ & $(0.78)$ \\
Cash & $0.03^{*}$ & 0.03 & -0.01 & 0.00 & $0.00^{* * *}$ & 0.00 & -0.05 & -0.17 \\
& $(1.85)$ & $(1.43)$ & $(-1.50)$ & $(-0.22)$ & $(3.65)$ & $(0.95)$ & $(-0.66)$ & $(-1.54)$ \\
Debt-to-capital & -0.23 & 0.62 & -0.05 & -0.20 & $0.07^{* * *}$ & -0.03 & 1.51 & 2.70 \\
& $(-0.83)$ & $(1.01)$ & $(-0.41)$ & $(-0.75)$ & $(4.31)$ & $(-1.18)$ & $(1.25)$ & $(0.97)$ \\
Market-to-book & $-0.10^{* *}$ & -0.06 & $-0.07^{* * *}$ & $-0.10^{* * *}$ & $0.01^{*}$ & $-0.01^{* *}$ & 0.05 & $-0.55^{*}$ \\
& $(-2.04)$ & $(-1.00)$ & $(-3.43)$ & $(-3.68)$ & $(1.94)$ & $(-2.55)$ & $(0.25)$ & $(-1.90)$ \\
Constant & $-1.85^{* *}$ & -2.28 & 0.06 & -0.01 & 0.03 & $0.19^{* *}$ & -0.63 & 9.88 \\
& $(-2.18)$ & $(-1.21)$ & $(0.16)$ & $(-0.01)$ & $(0.55)$ & $(2.28)$ & $(-0.17)$ & $(1.12)$ \\
Year fixed effects & yes & yes & yes & yes & yes & yes & yes & yes \\
Bank fixed effects & no & yes & no & yes & no & yes & no & yes \\
Observations & 226 & 226 & 226 & 226 & 195 & 195 & 194 & 194 \\
$R^{2}$ & 0.20 & 0.32 & 0.19 & 0.36 & 0.70 & 0.88 & 0.06 & 0.18 \\
\hline
\end{tabular}


Table XIII: Settlements and banks' systemic risk.

This table shows the estimated coefficients and $t$-statistics (in parentheses) of regressions on the three mean daily systemic risk measures in the following year $t+1 . \Delta C o V a R_{i t+1}$ is the conditional value at risk of the financial system conditional on bank $i$ being under distress in excess of the CoVaR of the financial system conditional on bank $i$ 's median state as proposed by Adrian and Brunnermeier (2016), MES $i t+1$ is the marginal expected shortfall and represents the equity losses of bank $i$ conditional on the financial system being under distress as proposed by Acharya et al. (2017), and $S R I S K_{i t+1}$ measures bank $i$ 's capital shortfall dependent on the financial system being under distress as a percentage of the total shortfall of the financial system as proposed by Brownlees and Engle (2017). The standard errors used to calculate the $t$-statistics (in parentheses) are clustered by bank. We estimate two regression models. Model I includes year fixed effects and Model II includes year as well as bank fixed effects. The explanatory variables $R M P_{i t}$, Revenue $_{i t}$, and $C_{a s h}$ it relate to bank $i$ 's total monetary penalties paid during year $t$, its revenue, and cash at the end of year $t$, all divided by bank $i$ 's market value at the end of year $t$. $\lg A s s e t s_{i t}$ relates to bank $i$ 's common logarithm of total assets at the end of year $t$. Debt-to-capital ${ }_{\text {it }}$ is bank $i$ 's ratio of total debt and total capital at the end of year $t$, and Market-to-book $k_{i t}$ is bank $i$ 's market value divided by its book equity value at the end of year $t$. ${ }^{* * *},{ }^{* * *}$ denote statistical significance at the $10 \%, 5 \%$, and $1 \%$ level, respectively.

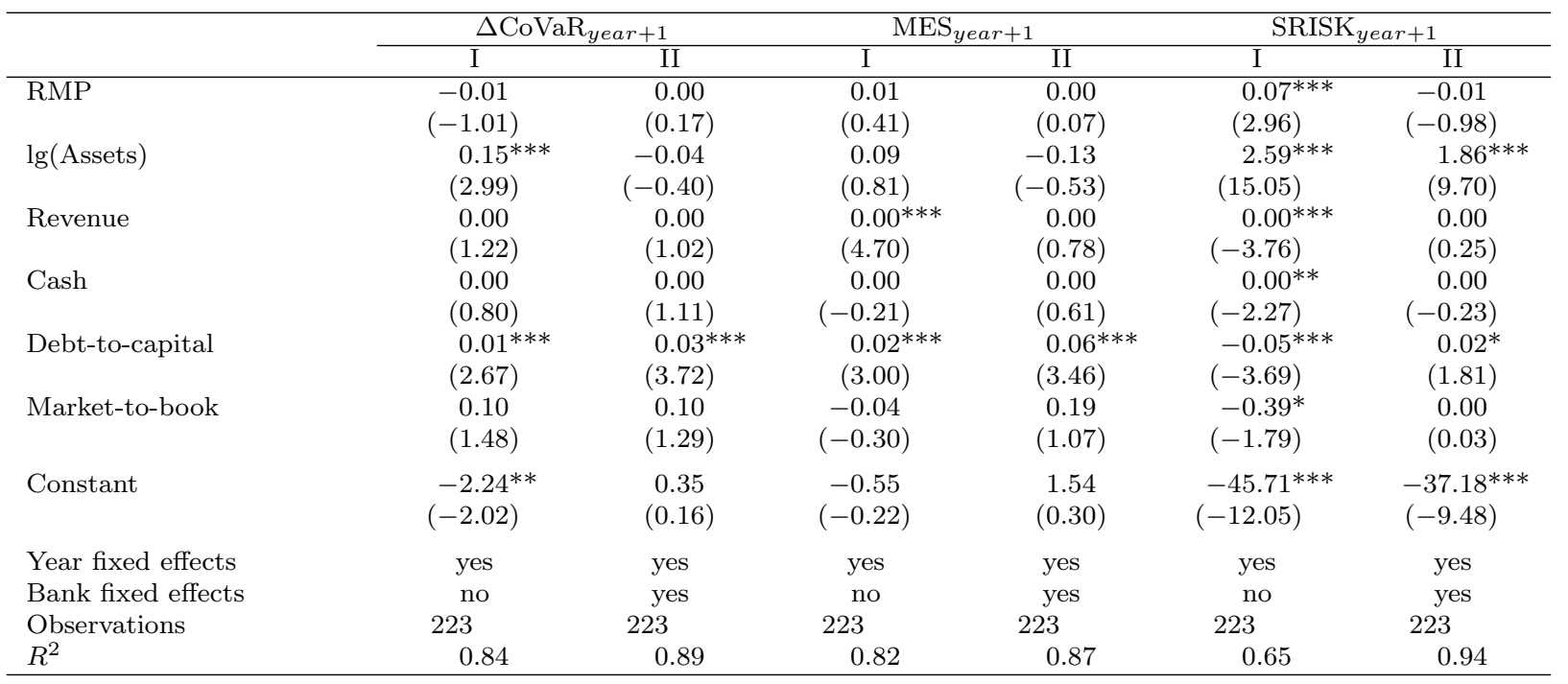


Table XIV: Penalties and bank characteristics.

This table shows the estimated coefficients and $t$-statistics (in parentheses) of regressions on $R M P_{i t+1}$, the relative monetary penalty. It relates to all financial penalties paid by bank $i$ in year $t+1$ divided by its market value at the end of year $t+1$. The standard errors used to calculate the $t$-statistics (in parentheses) are clustered by bank. We estimate two regression models. Model I includes year fixed effects and Model II includes year as well as bank fixed effects. The explanatory systemic risk variables relate to their respective mean daily value in year $t . \Delta C o V a R_{i t}$ is the conditional value at risk of the financial system conditional on bank $i$ being under distress in excess of the CoVaR of the financial system conditional on bank $i$ 's median state as proposed by Adrian and Brunnermeier (2016), MES $S_{i t}$ is the marginal expected shortfall and represents the equity losses of bank $i$ conditional on the financial system being under distress as proposed by Acharya et al. (2017), and $S R I S K_{i t}$ measures bank $i$ 's capital shortfall dependent on the financial system being under distress as a percentage of the total shortfall of the financial system as proposed by Brownlees and Engle (2017). The explanatory variable $\lg$ Assets $s_{i t}$ relates to bank $i$ 's common logarithm of total assets at the end of year $t$. Revenue it and Cashit relate to bank $i$ 's revenue and cash at the end of year $t$, divided by bank $i$ 's market value at the end of year $t$. Debt-to-capital $l_{i t}$ is bank $i$ 's ratio of total debt and total capital at the end of year $t$, and Market-to-book $k_{i t}$ is bank $i$ 's market value divided by its book equity value at the end of year $t$. ${ }^{*},{ }^{* *},{ }^{* * *}$ denote statistical significance at the $10 \%, 5 \%$, and $1 \%$ level, respectively.

\begin{tabular}{|c|c|c|c|c|c|c|}
\hline & & & RMP & +1 & & \\
\hline & $\mathrm{I}$ & II & $\mathrm{I}$ & II & $\mathrm{I}$ & II \\
\hline$\Delta \mathrm{CoVaR}$ & $\begin{array}{c}-1.08 \\
(-1.57)\end{array}$ & $\begin{array}{c}-0.89 \\
(-1.15)\end{array}$ & & & & \\
\hline MES & & & $\begin{array}{c}-0.05 \\
(-0.14)\end{array}$ & $\begin{array}{c}-0.40 \\
(-1.17)\end{array}$ & & \\
\hline SRISK & & & & & $\begin{array}{l}0.79^{* * *} \\
(4.11)\end{array}$ & $\begin{array}{c}0.70 \\
(1.38)\end{array}$ \\
\hline $\lg$ (Assets) & $\begin{array}{l}1.66^{* * *} \\
(3.66)\end{array}$ & $\begin{array}{c}0.42 \\
(0.40)\end{array}$ & $\begin{array}{l}1.54^{* * *} \\
(3.43)\end{array}$ & $\begin{array}{c}0.41 \\
(0.39)\end{array}$ & $\begin{array}{c}-0.69 \\
(-0.99)\end{array}$ & $\begin{array}{c}-1.38 \\
(-0.81)\end{array}$ \\
\hline Revenue & $\begin{array}{c}0.00 \\
(-1.06)\end{array}$ & $\begin{array}{c}0.00 \\
(0.46)\end{array}$ & $\begin{array}{c}0.00 \\
(-1.14)\end{array}$ & $\begin{array}{c}0.00 \\
(0.54)\end{array}$ & $\begin{array}{c}0.00 \\
(-0.29)\end{array}$ & $\begin{array}{c}0.00 \\
(0.16)\end{array}$ \\
\hline Cash & $\begin{array}{c}0.00 \\
(-0.49)\end{array}$ & $\begin{array}{c}0.00 \\
(-0.82)\end{array}$ & $\begin{array}{c}0.00 \\
(-0.57)\end{array}$ & $\begin{array}{c}0.00 \\
(-0.81)\end{array}$ & $\begin{array}{c}0.00 \\
(-0.07)\end{array}$ & $\begin{array}{c}0.00 \\
(-0.73)\end{array}$ \\
\hline Debt-to-capital & $\begin{array}{c}0.00 \\
(-0.10)\end{array}$ & $\begin{array}{l}-0.06 \\
(-0.84)\end{array}$ & $\begin{array}{l}-0.01 \\
(-0.21)\end{array}$ & $\begin{array}{c}-0.06 \\
(-0.84)\end{array}$ & $\begin{array}{c}0.02 \\
(0.56)\end{array}$ & $\begin{array}{l}-0.08 \\
(-1.09)\end{array}$ \\
\hline Market-to-book & $\begin{array}{c}0.38 \\
(0.69)\end{array}$ & $\begin{array}{l}1.46^{* *} \\
(2.05)\end{array}$ & $\begin{array}{c}0.30 \\
(0.54)\end{array}$ & $\begin{array}{l}1.45^{* *} \\
(2.03)\end{array}$ & $\begin{array}{c}0.31 \\
(0.59)\end{array}$ & $\begin{array}{r}1.22^{*} \\
(1.70)\end{array}$ \\
\hline Constant & $\begin{array}{l}-30.74^{* * *} \\
(-3.13)\end{array}$ & $\begin{array}{c}-2.52 \\
(-0.11)\end{array}$ & $\begin{array}{l}-29.56^{* * *} \\
(-3.00)\end{array}$ & $\begin{array}{c}-2.41 \\
(-0.11)\end{array}$ & $\begin{array}{l}11.20 \\
(0.82)\end{array}$ & $\begin{array}{l}33.12 \\
(0.95)\end{array}$ \\
\hline Year fixed effects & yes & yes & yes & yes & yes & yes \\
\hline Bank fixed effects & no & yes & no & yes & no & yes \\
\hline Observations & 228 & 228 & 228 & 228 & 228 & 228 \\
\hline$R^{2}$ & 0.22 & 0.36 & 0.21 & 0.36 & 0.27 & 0.36 \\
\hline
\end{tabular}


Figure I: Development of bank litigation.

This figure shows the development of the cumulative total monetary penalties (TMP), which are the sum of all penalties related to the resolution announcement, and the number of lawsuit resolutions associated with penalties in excess of 5 million US dollars that involved at least one of the 25 largest global financial institutions, based on a hand-collected dataset of 409 events between 2005 and 2015 .

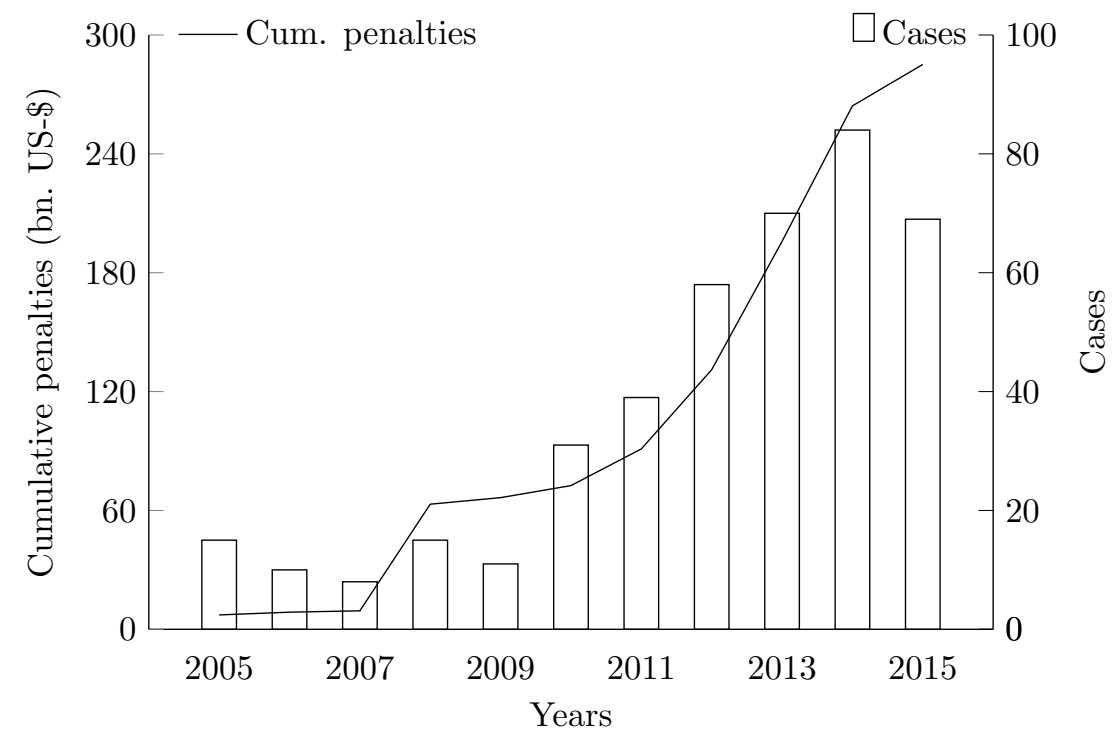

Figure II: Penalty flows within and across the United States and Europe.

This figure shows the amounts of penalties assigned by US and European law enforcers, as well as the amounts assigned to US and European banks. The bubbles' locations indicate whether the penalties have been assigned by or to US or European law enforcers. The arrows indicate to which banks these penalties were assigned. The bubble and arrow sizes are proportional to the respective penalty amounts. The bank bubbles are furthermore subdivided with respect to the banks with the largest share of penalties. The symbol BOA stands for Bank of America, JPM for JPMorgan Chase, CITI for Citigroup, UBS for UBS, DB for Deutsche Bank, BNP for BNP Paribas, and BARC for Barclays.

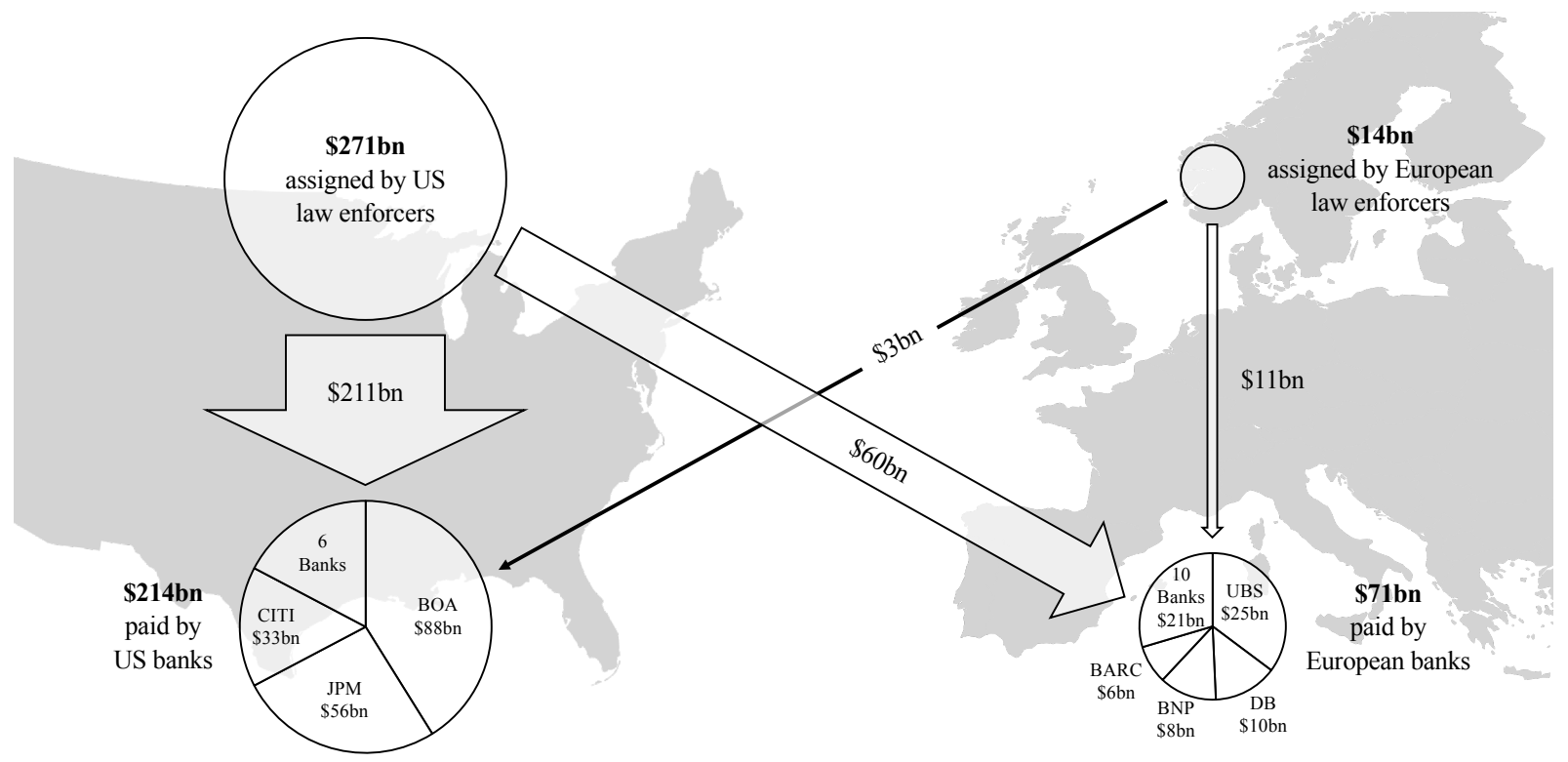


Figure III: Categorization of bank litigation.

This figure shows the classification of the various resolution events. The first column shows the plaintiff or prosecutor. The second column defines the means of law enforcement and the third column defines the ways to end the enforcement process, which can generally be through a settlement or a disputed decision.

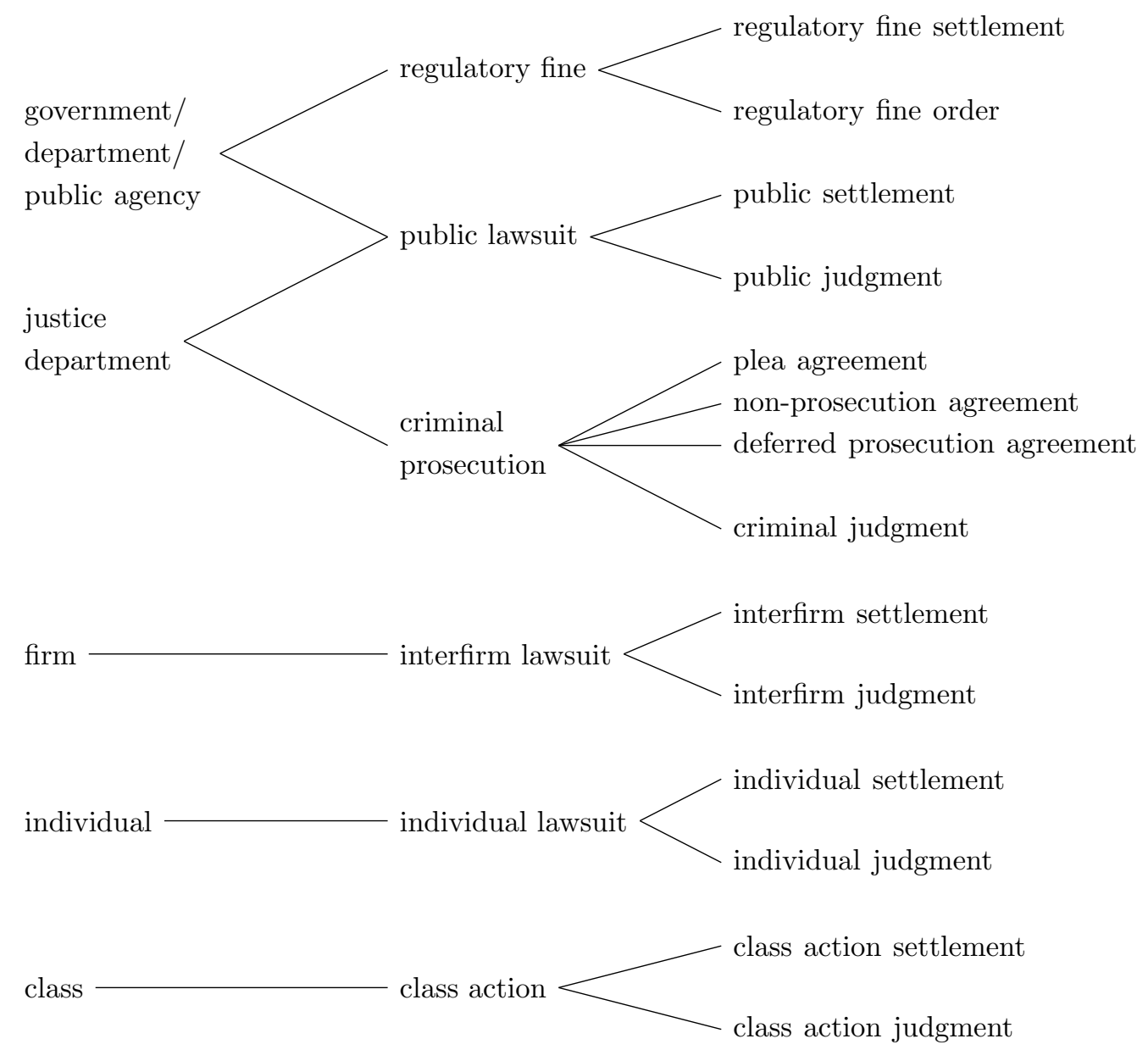


We thank two anonymous referees, Douglas Cumming (the Editor), Björn Imbierowicz, Steven Ongena, and the participants of the 2018 AFFI conference for their helpful comments and suggestions on earlier drafts of this paper. We also thank Michael Zimmermann for his valuable research assistance.

This research did not receive any specific grant from funding agencies in the public, commercial, or not-for-profit sectors. 


\section{References}

Acharya, V., Engle, R., and Richardson, M. (2012). Capital Shortfall: A New Approach to Ranking and Regulating Systemic Risks. American Economic Review, 102, 59-64. doi:10.1257/aer.102.3.59,

Acharya, V. V., and Johnson, T. C. (2007). Insider trading in credit derivatives. Journal of Financial Economics, 84, 110-141. doi:10.1016/j.jfineco.2006.05.003.

Acharya, V. V., Pedersen, L. H., Philippon, T., and Richardson, M. (2017). Measuring systemic risk. Review of Financial Studies, 30, 2-47. doi:10.1093/rfs/hhw088.

Adrian, T., and Brunnermeier, M. K. (2016). CoVaR. American Economic Review, 106 , 1705-1741. doi:10.1257/aer.20120555.

Agrawal, A., Jaffe, J. F., and Karpoff, J. M. (1999). Management Turnover and Governance Changes Following the Revelation of Fraud. The Journal of Law and Economics, 42, 309-342. doi:10.1086/467427.

Alexander, C. R., and Cohen, M. A. (2015). Evolution of corporate criminal settlements: An empirical perspective on non-prosection, deferred prosecution, and plea agreements. American Criminal Law Review, 52, 537-593.

Amici, A., Fiordelisi, F., Masala, F., Ricci, O., and Sist, F. (2013). Value creation in banking through strategic alliances and joint ventures. Journal of Banking \& Finance, 37, 1386-1396. doi:10.1016/j.jbankfin.2012.03.028.

Arlen, J. (2011). Removing Prosecutors from the Boardroom: Limiting Prosecutorial Discretion to Impose Structural Reforms. In A. S. Barkow, and R. E. Barkow (Eds.), Prosecutors in the boardroom: Using criminal law to regulate corporate conduct (pp. 62-86). New York: New York University Press.

Armour, J., Mayer, C., and Polo, A. (2017). Regulatory Sanctions and Reputational Damage in Financial Markets. Journal of Financial and Quantitative Analysis, 52, 1429-1448. doi:10.1017/S0022109017000461.

Baker, S. R., Bloom, N., and Davis, S. J. (2016). Measuring Economic Policy Uncertainty. The Quarterly Journal of Economics, 131, 1593-1636. doi:10.1093/qje/qjw024. arXiv:9809069v1.

Benoit, S., Colliard, J.-E., Hurlin, C., and Pérignon, C. (2017). Where the Risks Lie: A Survey on Systemic Risk. Review of Finance, 21, 109-152. doi:10.1093/rof/rfw026.

Berger, A. N., Guedhami, O., Kim, H. H., and Li, X. (2020). Economic policy uncertainty and bank liquidity hoarding. Journal of Financial Intermediation, in press. doi:10.1016/ j.jfi.2020.100893.

Bessembinder, H., Kahle, K. M., Maxwell, W. F., and Xu, D. (2009). Measuring Abnormal Bond Performance. Review of Financial Studies, 22, 4219-4258. doi:10.1093/rfs/ hhn105. 
Bhagat, S., Bizjak, J., and Coles, J. L. (1998). The shareholder wealth implications of corporate lawsuits. Financial Management, 27, 5-27. doi:10.2307/3666410.

Bhagat, S., Brickley, J. A., and Coles, J. L. (1994). The costs of inefficient bargaining and financial distress: Evidence from corporate lawsuits. Journal of Financial Economics, 35, 221-247. doi:10.1016/0304-405X(94)90005-1.

Bizjak, J. M., and Coles, J. L. (1995). The effect of private antitrust litigation on the stock-market valuation of the firm. American Economic Review, 85, 436-461.

Blanco, R., Brennan, S., and Marsh, I. W. (2005). An Empirical Analysis of the Dynamic Relation between Investment-Grade Bonds and Credit Default Swaps. The Journal of Finance, 60, 2255-2281. doi:10.1111/j.1540-6261.2005.00798.x.

Boehmer, E., Musumeci, J., and Poulsen, A. B. (1991). Event-study methodology under conditions of event-induced variance. Journal of Financial Economics, 30, 253-272. doi: $10.1016 / 0304-405 \mathrm{X}(91) 90032-\mathrm{F}$.

Bordo, M. D., Duca, J. V., and Koch, C. (2016). Economic policy uncertainty and the credit channel: Aggregate and bank level U.S. evidence over several decades. Journal of Financial Stability, 26, 90-106. doi:10.1016/j·jfs.2016.07.002.

Brous, P. A., and Leggett, K. (1996). Wealth effects of enforcement actions against financially distressed banks. Journal of Financial Research, 19, 561-577. doi:10.1111/j.1475-6803. 1996.tb00230.x.

Brown, K. C., Harlow, W., and Tinic, S. M. (1988). Risk aversion, uncertain information, and market efficiency. Journal of Financial Economics, 22, 355-385. doi:10.1016/0304405X (88) 90075-X.

Brown, S. J., and Warner, J. B. (1985). Using daily stock returns. Journal of Financial Economics, 14, 3-31. doi:10.1016/0304-405X(85)90042-X.

Brownlees, C., and Engle, R. F. (2017). SRISK: A Conditional Capital Shortfall Measure of Systemic Risk. Review of Financial Studies, 30, 48-79. doi:10.1093/rfs/hhw060.

Brownlees, C. T., and Engle, R. F. (2012). Volatility, Correlation and Tails for Systemic Risk Measurement. SSRN Electronic Journal, . doi:10.2139/ssrn.1611229.

Brunnermeier, M., Rother, S., and Schnabel, I. (2020). Asset Price Bubbles and Systemic Risk. Review of Financial Studies, 33, 4272-4317. doi:10.1093/rfs/hhaa011.

Bulan, L. T., Ryan, E. M., and Simmons, L. E. (2016). Securities Class Action Settlements: 2015 Review and Analysis, Cornerstone Research.

Choi, H. M., Karpoff, J. M., Lou, X., and Martin, G. S. (2019). Enforcement Waves and Spillovers. SSRN Electronic Journal, . doi:10.2139/ssrn.3526555.

Choi, I. (2001). Unit root tests for panel data. Journal of International Money and Finance, 20, 249-272. doi:10.1016/S0261-5606(00)00048-6. 
Corrado, C. J. (1989). A nonparametric test for abnormal security-price performance in event studies. Journal of Financial Economics, 23, 385-395. doi:10.1016/0304-405X (89) 90064-0.

Corrado, C. J., and Zivney, T. L. (1992). The Specification and Power of the Sign Test in Event Study Hypothesis Tests Using Daily Stock Returns. Journal of Financial and Quantitative Analysis, 27, 465. doi:10.2307/2331331.

Delis, M. D., Iosifidi, M., Kokas, S., Xefteris, D., and Ongena, S. (2020). Enforcement actions on banks and the structure of loan syndicates. Journal of Corporate Finance, 60. doi:10.1016/j.jcorpfin.2019.101527.

Delis, M. D., Staikouras, P. K., and Tsoumas, C. (2017). Formal enforcement actions and bank behavior. Management Science, 63, 959-987. doi:10.1287/mnsc.2015.2343.

Deng, S., Willis, R. H., and Xu, L. (2014). Shareholder Litigation, Reputational Loss, and Bank Loan Contracting. Journal of Financial and Quantitative Analysis, 49, 1101-1132. doi:10.1017/S002210901400057X.

Dodd, P., and Warner, J. B. (1983). On corporate governance. Journal of Financial Economics, 11, 401-438. doi:10.1016/0304-405X (83)90018-1.

Eberhart, A. C., and Siddique, A. (2002). The long-term performance of corporate bonds (and stocks) following seasoned equity offerings. Review of Financial Studies, 15, 13851406. doi:10.1093/rfs/15.5.1385.

Ederington, L., Guan, W., and Yang, L. (2015). Bond market event study methods. Journal of Banking \& Finance, 58, 281-293. doi:10.1016/j.jbankfin.2015.03.013.

European Systemic Risk Board (2015). Report on misconduct risk in the banking sector. URL: http://www.esrb.europa.eu/pub/pdf/other/150625_report_misconduct_ risk.en.pdf.

Flore, C., Kolaric, S., and Schiereck, D. (2017). Settlement agreement types of federal corporate prosecution in the U.S. and their impact on shareholder wealth. Journal of Business Research, 76, 145-158. doi:10.1016/j.jbusres.2017.03.015.

Freifeld, K., Viswanatha, A., and Henry, D. (2013). JPMorgan agrees $\$ 13$ billion settlement with U.S. over bad mortgages. URL: https://www.reuters.com/article/usjpmorgan-settlement/jpmorgan-agrees-13-billion-settlement-with-u-s-overbad-mortgages-idUSBRE9AI00A20131120.

Galil, K., and Soffer, G. (2011). Good news, bad news and rating announcements: An empirical investigation. Journal of Banking \& Finance, 35, 3101-3119. doi:10.1016/j. jbankfin.2011.04.010.

Gande, A., and Lewis, C. M. (2009). Shareholder-Initiated Class Action Lawsuits: Shareholder Wealth Effects and Industry Spillovers. Journal of Financial and Quantitative Analysis, 44, 823-850. doi:10.1017/S0022109009990202. 
Glazer, E. (2014). J.P. Morgan Being Probed by Justice Department. URL: https: //www.wsj . com/articles/j-p-morgan-being-probed-by-justice-department1415054825?mod=WSJ_hp_LEFTWhatsNewsCollection.

Huang, X., Rui, Y., Shen, J., and Tian, G. Y. (2017). U.S. class action lawsuits targeting foreign firms: The country spillover effect. Journal of Corporate Finance, 45, 378-400. doi:10.1016/j.jcorpfin.2017.05.011.

Im, K. S., Pesaran, M., and Shin, Y. (2003). Testing for unit roots in heterogeneous panels. Journal of Econometrics, 115, 53-74. doi:10.1016/S0304-4076(03)00092-7.

Jickling, M., and Murphy, E. V. (2010). Who regulates whom? An overview of U.S. financial supervision. Technical Report Congressional Research Service. URL: https://fas.org/ sgp/crs/misc/R40249.pdf.

Jordan, J. S., Peek, J., and Rosengren, E. S. (2000). The market reaction to the disclosure of supervisory actions: Implications for bank transparency. Journal of Financial Intermediation, 9, 298-319. doi:10.1006/jfin.2000.0292.

Jorion, P., and Zhang, G. (2007). Good and bad credit contagion: Evidence from credit default swaps. Journal of Financial Economics, 84, 860-883. doi:10.1016/j.jfineco. 2006.06 .001 .

Karpoff, J. M., Lee, D. S., and Martin, G. S. (2008). The Cost to Firms of Cooking the Books. Journal of Financial and Quantitative Analysis, 43, 581-611. doi:10.1017/ S0022109000004221.

Karpoff, J. M., Lee, D. S., and Martin, G. S. (2017). The impact of anti-bribery enforcement actions on targeted firms. SSRN Electronic Journal, . doi:10.2139/ssrn.1573222.

Karpoff, J. M., and Lott, J. R. (1993). The Reputational Penalty Firms Bear from Committing Criminal Fraud. The Journal of Law and Economics, 36, 757-802. doi:10.1086/ 467297.

Karpoff, J. M., Lott, J. R., Jr., and Wehrly, E. W. (2005). The Reputational Penalties for Environmental Violations: Empirical Evidence. The Journal of Law and Economics, 48, 653-675. doi:10.1086/430806.

Kiesel, F., Kolaric, S., and Schiereck, D. (2016). Market integration and efficiency of CDS and equity markets. Quarterly Review of Economics and Finance, 61, 209-229. doi:10. $1016 /$ j.qref .2016.02.010.

Köster, H., and Pelster, M. (2017). Financial penalties and bank performance. Journal of Banking \& Finance, 79, 57-73. doi:10.1016/j.jbankfin.2017.02.009.

Kwan, S. H. (1996). Firm-specific information and the correlation between individual stocks and bonds. Journal of Financial Economics, 40, 63-80. doi:10.1016/0304-405X(95) 00836-4. 
Laeven, L., and Valencia, F. (2018). Systemic Banking Crises Revisited, WP/18/206, September 2018.

Levin, A., Lin, C. F., and Chu, C. S. J. (2002). Unit root tests in panel data: Asymptotic and finite-sample properties. Journal of Econometrics, 108, 1-24. doi:10.1016/S03044076(01) 00098-7.

Longstaff, F. A., Mithal, S., and Neis, E. (2005). Corporate Yield Spreads: Default Risk or Liquidity? New Evidence from the Credit Default Swap Market. The Journal of Finance, 60, 2213-2253. doi:10.1111/j.1540-6261.2005.00797.x.

Maul, D., and Schiereck, D. (2017). The bond event study methodology since 1974. Review of Quantitative Finance and Accounting, 48, 749-787. doi:10.1007/s11156-016-0562-4.

Mikkelson, W. H., and Partch, M. M. (1988). Withdrawn Security Offerings. Journal of Financial and Quantitative Analysis, 23, 119. doi:10.2307/2330876.

Norden, L. (2017). Information in CDS spreads. Journal of Banking E Finance, 75, 118-135. doi:10.1016/j.jbankfin.2016.11.007.

Norden, L., and Weber, M. (2009). The Co-movement of Credit Default Swap, Bond and Stock Markets: an Empirical Analysis. European Financial Management, 15, 529-562. doi: $10.1111 /$ j.1468-036X.2007.00427.x.

Pereira, J., Malafronte, I., Sorwar, G., and Nurullah, M. (2019). Enforcement Actions, Market Movement and Depositors' Reaction: Evidence from the US Banking System. Journal of Financial Services Research, 55, 143-165. doi:10.1007/s10693-019-00313-9.

Ricci, O. (2015). The impact of monetary policy announcements on the stock price of large European banks during the financial crisis. Journal of Banking 85 Finance, 52, 245-255. doi:10.1016/j.jbankfin.2014.07.001.

Roman, R. A. (2020). Winners and losers from supervisory enforcement actions against banks. Journal of Corporate Finance, 60. doi:10.1016/j.jcorpfin.2019.101516.

Slovin, M. B., Sushka, M. E., and Polonchek, J. A. (1999). An analysis of contagion and competitive effects at commercial banks. Journal of Financial Economics, 54, 197-225. doi:10.1016/s0304-405x(99)00036-7.

Tibbs, S. L., Harrell, D. L., and Shrieves, R. E. (2011). Do Shareholders Benefit from Corporate Misconduct? A Long-Run Analysis. Journal of Empirical Legal Studies, 8, 449-476. doi:10.1111/j.1740-1461.2011.01216.x. 


\section{Online Appendix A: Data description}

Table A.I: Further characteristics of bank litigation.

This table shows the characteristics of several subsamples of the database. The sum, mean, median, minimum, and maximum of the total monetary penalty (TMP), which represents the total amount of all monetary penalties connected to the resolution announcement, and of the relative monetary penalty (RMP), which represents the TMP relative to the bank's market value six months before the resolution announcement, are shown. The sum of the RMP is calculated as the sum of total monetary penalties paid relative to the respective banks' market values at the end of 2004. Additionally, the number of resolutions are given for every subsample. In Panel A the database is divided according to the resolution type (see also Figure III in Online Appendix A). Panel B shows the activity of different public authorities and plaintiffs (see also Figure III in Appendix A).

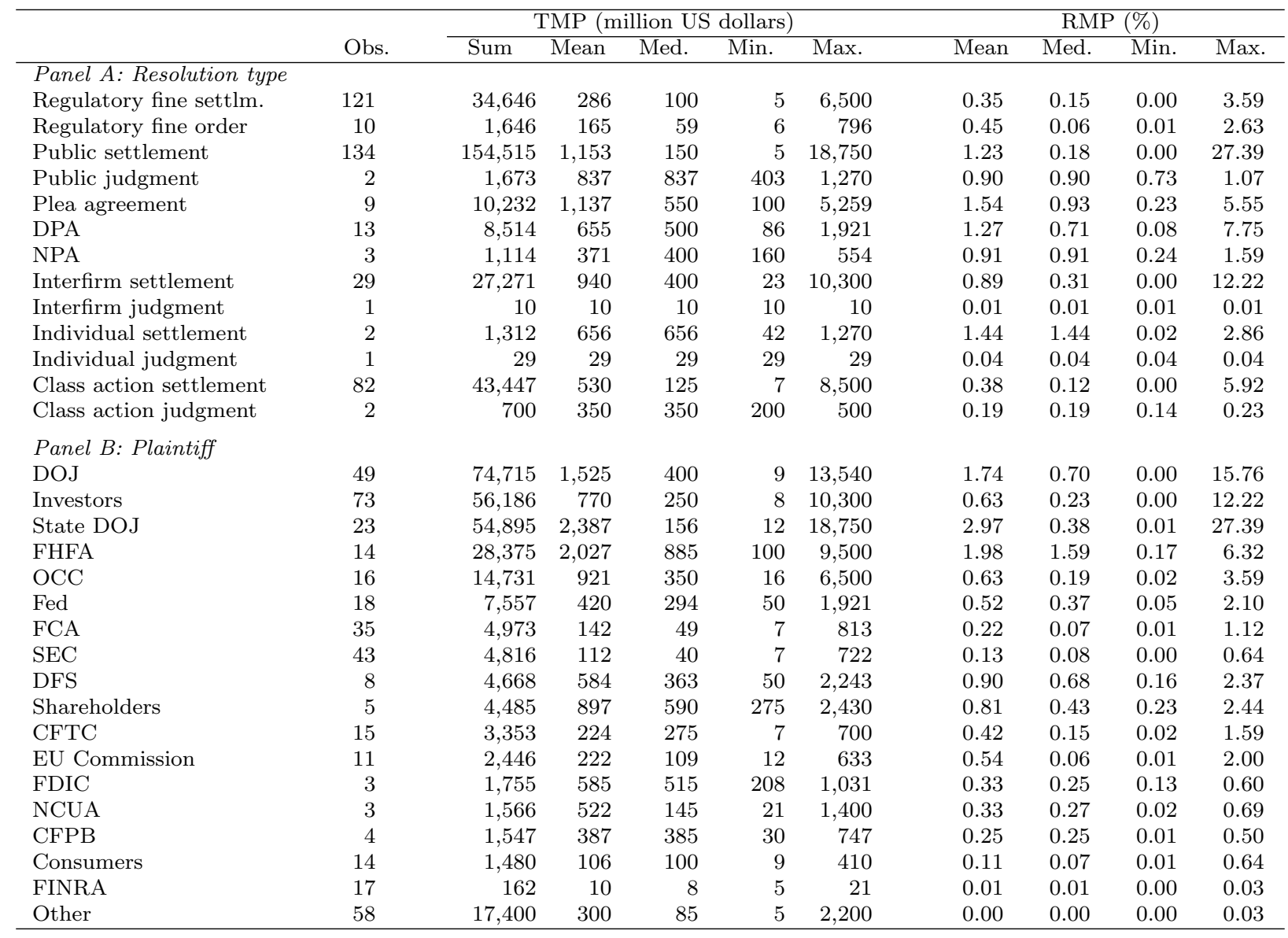


Table A.II: All law enforcers with respective penalties and case numbers.

This table shows all law enforcers in our database with the total number of monetary penalties assigned and the number of cases enforced. The panels separate these law enforcers according to their country. For each country the law enforcers are furthermore structured according to the law enforcer classification. The activities of the justice departments play a major role in banking law enforcement and are summarized under General law enforcement. The financial regulatory regime can be generally divided into two types of regulators. Financial institution regulators regulate particular types of institutions for risky behavior or conflicts of interest. Financial market regulators promulgate rules for certain financial transactions no matter what kind of institution engages in them. Private plaintiffs consist of the three major plaintiff groups investors, consumers, and shareholders. All three groups often bring class action lawsuits, while institutional investors frequently also bring single-plaintiff lawsuits. Under Non-financial regulators we subsume all regulators which do not mainly regulate the financial industry. All law enforcers marked with a "*” are described in more detail in Table II of the main paper.

\begin{tabular}{|c|c|c|}
\hline Law enforcer & TMP (million US-\$) & Cases \\
\hline Panel A: United States & 271,092 & 338 \\
\hline \multicolumn{3}{|l|}{ General law enforcement } \\
\hline *US Department of Justice (DOJ) & 74,715 & 49 \\
\hline *State Justice Department (SDOJ) & 54,895 & 23 \\
\hline \multicolumn{3}{|l|}{ Financial institutions regulators } \\
\hline *Federal Reserve (Fed) & 7,557 & 18 \\
\hline *Office of the Comptroller of the Currency (OCC) & 14,731 & 16 \\
\hline *Federal Housing Finance Agency (FHFA) & 28,375 & 14 \\
\hline *New York Department of Financial Services (DFS) & 4,668 & 8 \\
\hline *Federal Deposit Insurance Corporation (FDIC) & 1,755 & 3 \\
\hline National Credit Union Administration (NCUA) & 1,566 & 3 \\
\hline Texas State Securities Board (TSSB) & 7 & 1 \\
\hline \multicolumn{3}{|l|}{ Financial market regulators } \\
\hline$*^{*}$ Securities and Exchange Commission (SEC) & 4,816 & 43 \\
\hline *Commodity Futures Trading Commission (CFTC) & 3,353 & 15 \\
\hline *Financial Industry Regulatory Authority (FINRA) & 162 & 17 \\
\hline${ }^{*}$ Consumer Financial Protection Bureau (CFPB) & 1,547 & 4 \\
\hline North American Securities Administrators Association (NASAA) & 25 & 1 \\
\hline \multicolumn{3}{|l|}{ Private plaintiffs } \\
\hline *Investors & 55,075 & 69 \\
\hline *Consumers \& clients & 3,481 & 18 \\
\hline *Shareholders of different company & 4,882 & 5 \\
\hline *Shareholders & 4,485 & 5 \\
\hline Employees & 356 & 8 \\
\hline Chicago Board Options Exchange (CBOE) & 7 & 1 \\
\hline New York Stock Exchange (NYSE) & 50 & 1 \\
\hline National Fair Housing Alliance (NFHA) & 42 & 1 \\
\hline \multicolumn{3}{|l|}{ Non-financial regulators } \\
\hline Government & 1,163 & 5 \\
\hline Department of Housing and Urban Development (HUD) & 963 & 3 \\
\hline Office of Foreign Asset Control (OFAC) & 1,268 & 3 \\
\hline Federal Energy Regulatory Commission (FERC) & 898 & 2 \\
\hline Federal Trade Commission (FTC) & 108 & 1 \\
\hline Ginnie Mae & 144 & 1 \\
\hline Panel B: United Kingdom & 7,104 & 39 \\
\hline \multicolumn{3}{|l|}{ Financial institutions regulator } \\
\hline *Financial Conduct Authority & 4,973 & 35 \\
\hline Her Majesty's Treasury & 796 & 1 \\
\hline \multicolumn{3}{|l|}{ Private plaintiffs } \\
\hline${ }^{*}$ Consumers \& clients & 12 & 1 \\
\hline *Investors & 1,280 & 1 \\
\hline \multicolumn{3}{|l|}{ Non-financial regulators } \\
\hline Office of Fair Trading & 43 & 1 \\
\hline
\end{tabular}


Table A.II (continued): All law enforcers with respective penalties and case numbers.

\begin{tabular}{|c|c|c|}
\hline Law enforcer & TMP (million US-\$) & Cases \\
\hline $\begin{array}{l}\text { Panel C: European Union } \\
\text { Non-financial regulators }\end{array}$ & 2,446 & 11 \\
\hline *EU Commission & 2,446 & 11 \\
\hline $\begin{array}{l}\text { Panel D: France } \\
\quad \text { Financial institutions regulator }\end{array}$ & 292 & 6 \\
\hline $\begin{array}{l}\text { Prudential Supervision and Resolution Authority (ACPR) } \\
\text { Non-financial regulators }\end{array}$ & 13 & 1 \\
\hline Autorite de la concurrence & 279 & 5 \\
\hline $\begin{array}{l}\text { Panel E: Italy } \\
\quad \text { Private plaintiffs }\end{array}$ & 789 & 4 \\
\hline *Investors & 789 & 4 \\
\hline $\begin{array}{l}\text { Panel F: Ireland IE } \\
\quad \text { Financial institutions regulator }\end{array}$ & 453 & 4 \\
\hline $\begin{array}{l}\text { Central Bank of Ireland } \\
\text { Private plaintiffs }\end{array}$ & 78 & 1 \\
\hline *Investors & 375 & 3 \\
\hline $\begin{array}{l}\text { Panel G: Germany } \\
\quad \text { General law enforcement }\end{array}$ & 2,686 & 4 \\
\hline $\begin{array}{l}\text { Staatsanwaltschaft } \\
\text { Private plaintiffs }\end{array}$ & 606 & 2 \\
\hline $\begin{array}{l}\text { *Investors } \\
\text { Leo Kirch (heirs) }\end{array}$ & $\begin{array}{r}810 \\
1,270\end{array}$ & $\begin{array}{l}1 \\
1\end{array}$ \\
\hline $\begin{array}{l}\text { Panel H: Switzerland } \\
\text { Financial institutions regulator } \\
\quad \text { *Financial Market Supervisory Authority (FINMA) }\end{array}$ & 246 & 3 \\
\hline Grand Total & 285,108 & 409 \\
\hline
\end{tabular}


Table A.III: Sample of excluded events description.

This table shows the number of observations (N), mean, median, standard deviation, minimum, 25th percentile, 75 th percentile, and the maximum of several variables used in the empirical analysis for the sample of events which had to be excluded from analysis. $\lg$ (Assets) is equal to the common logarithm of the bank's total assets in million US dollars at the end of the year prior to the settlement. The variable Volatility accounts for the recent six-month stock volatility. The variable Cash flow measures the size of a bank's cash flows divided by its market value, Net income measures its profitability through the ratio of a bank's net income divided by its market value, and Debt-to-capital measures a bank's leverage through its ratio of debt to capital. All three variables relate to the end of the year prior to the event. TMP represents the total monetary size of the settlement in million US dollars and the relative monetary penalty $(R M P)$ represents the TMP divided by the bank's market value six month prior to the settlement. Multiple is a binary variable which equals one if more than one settlement for that bank is announced at the same time, and zero otherwise. The variable Crime is equal to one if a criminal prosecution is settled, and zero otherwise. US is a binary variable that is equal to one if a plaintiff or regulator is from the US, and zero otherwise. The variable Crisis is equal to one in case the resolution announcement lies between 2007 and 2011, and zero otherwise.

\begin{tabular}{lcrrrrrrr}
\hline & $\mathrm{N}$ & Mean & Median & Std. dev. & Min. & 25th perc. & 75 th perc. & Max. \\
\hline $\lg$ (Assets) & 91 & 7.23 & 7.28 & 0.39 & 5.95 & 6.93 & 7.55 & 7.77 \\
Volatility (\%) & 91 & 2.79 & 2.39 & 1.90 & 0.92 & 1.53 & 3.30 & 12.51 \\
Cash flow (\%) & 91 & 17.13 & 17.71 & 24.37 & -66.39 & 9.98 & 23.82 & 135.32 \\
Net income (\%) & 91 & 3.79 & 6.32 & 13.14 & -49.96 & 1.46 & 9.13 & 73.14 \\
Debt-to-capital (\%) & 91 & 80.55 & 82.60 & 9.19 & 55.18 & 73.68 & 87.50 & 94.80 \\
TMP (mio. US-\$) & 91 & 670.69 & 150.00 & $1,946.69$ & 5.00 & 29.00 & 487.90 & $13,199.95$ \\
RMP (\%) & 91 & 0.95 & 0.20 & 2.75 & 0.01 & 0.04 & 0.71 & 20.23 \\
Multiple & 91 & 0.10 & 0.00 & 0.30 & 0.00 & 0.00 & 0.00 & 1.00 \\
Crime & 91 & 0.07 & 0.00 & 0.25 & 0.00 & 0.00 & 0.00 & 1.00 \\
US & 91 & 0.75 & 1.00 & 0.44 & 0.00 & 0.00 & 1.00 & 1.00 \\
\hline
\end{tabular}

Table A.IV: Sample for panel analysis description.

This table shows the number of observations (N), mean, median, standard deviation, minimum, 25th percentile, 75 th percentile, and the maximum of several variables used in the empirical analysis. $R M P$ is the ratio of all monetary penalties paid in a given year by a bank and its market value at the end of the year. lg(Assets) is equal to the common logarithm of a bank's total assets in million US dollars at the end of the year, Revenues is a bank's revenues divided by its market value at the end of the year, Cash is a bank's cash holdings divided by its market value at the end of the year, Debt-to-capital measures a bank's leverage through its ratio of debt to capital at the end of the year, Market-to-book measures a bank's valuation through its ratio of the market value of common equity divided by its book value at the end of the year, Cash flow measures the size of a bank's cash flow divided by its market value at the end of the year, Net income measures a bank's profitability through the ratio of a bank's net income divided by its market value at the end of the year, Tier 1 ratio is the ratio of tier 1 capital to total risk-weighted assets at the end of the year, and Loan growth is a bank's end of year total loans year over year growth rate. The systemic risk measures relate to the mean daily risk measure in the following year. $\triangle \mathrm{Co} V a R$ is the conditional value at risk of the financial system conditional on a bank being under distress in excess of the CoVaR of the financial system conditional on a bank's median state as proposed by Adrian and Brunnermeier (2016), MES is the marginal expected shortfall and represents the equity losses of a bank conditional on the financial system being under distress as proposed by Acharya et al. (2017), and SRISK measures a bank's capital shortfall dependent on the financial system being under distress as a percentage of the total shortfall of the financial system as proposed by Brownlees and Engle (2017).

\begin{tabular}{|c|c|c|c|c|c|c|c|c|}
\hline & $\mathrm{N}$ & Mean & Median & Std. dev. & Min. & 25 th perc. & 75th perc. & Max. \\
\hline RMP (\%) & 226 & 1.41 & 0.02 & 3.81 & 0.00 & 0.00 & 0.84 & 28.93 \\
\hline $\lg ($ Assets $)$ & 226 & 20.83 & 20.92 & 0.53 & 18.64 & 20.56 & 21.22 & 21.67 \\
\hline Revenues (\%) & 226 & 127.26 & 97.94 & 94.40 & 26.77 & 63.99 & 145.77 & 602.66 \\
\hline Cash $(\%)$ & 226 & 117.18 & 70.68 & 133.95 & 4.89 & 24.82 & 151.61 & 740.10 \\
\hline Debt-to-capital (\%) & 226 & 81.12 & 82.63 & 9.01 & 53.73 & 75.17 & 88.23 & 96.02 \\
\hline Market-to-book & 226 & 1.18 & 1.06 & 0.69 & 0.19 & 0.63 & 1.56 & 4.38 \\
\hline Cash flow (\%) & 226 & 18.67 & 16.02 & 30.34 & -181.35 & 9.49 & 26.27 & 135.32 \\
\hline Net income (\%) & 226 & 5.60 & 8.22 & 13.51 & -93.30 & 3.12 & 10.51 & 73.14 \\
\hline Tier 1 ratio (\%) & 195 & 11.56 & 11.70 & 2.86 & 6.62 & 8.95 & 13.40 & 21.30 \\
\hline Loan growth (\%) & 194 & 9.41 & 3.46 & 23.64 & -23.94 & -2.87 & 14.46 & 147.39 \\
\hline$\Delta \mathrm{CoVaR}_{\text {year }+1}(\%)$ & 223 & 1.85 & 1.57 & 0.88 & 0.18 & 1.22 & 2.30 & 4.48 \\
\hline $\mathrm{MES}_{\text {year }+1}(\%)$ & 223 & 3.80 & 3.15 & 1.87 & 1.22 & 2.39 & 4.91 & 9.66 \\
\hline SRISK $_{\text {year }+1}(\%)$ & 223 & 3.43 & 2.93 & 2.03 & 0.34 & 2.19 & 4.11 & 9.54 \\
\hline
\end{tabular}




\section{Online Appendix B: Event study specifications}

Table B.I: Event study specifications.

This table shows the mean, median, minimum, 25th percentile, 75 th percentile, and maximum values of various specifications of the comparable bank stock, bond, and CDS event study. For the comparable bank stock event study the number of comparable banks are shown. For the bond event study the number of firm bonds included in the company portfolio, the average firm bond rating of the company portfolio, and the number of bonds in the matching portfolio are shown. The average firm bond rating is calculated with the help of a numerical assignment (Aaa - 1, Aa - 2, A - 3, Baa - 4, Ba - 5, B - 6, B and less - 7) and corresponds, depending on availability, on Standard \& Poor's and Moody's bond rating. Concerning the CDS event study, Moody's long-term issuer rating is shown, as well as the number of CDS in the matching portfolio.

\begin{tabular}{|c|c|c|c|c|c|c|}
\hline & \multirow[b]{2}{*}{$\begin{array}{l}\text { Comparable } \\
\text { banks }\end{array}$} & \multicolumn{3}{|c|}{ Bond event study } & \multicolumn{2}{|c|}{ CDS event study } \\
\hline & & $\begin{array}{l}\text { Firm } \\
\text { bonds }\end{array}$ & $\begin{array}{c}\text { Average } \\
\text { rating }\end{array}$ & $\begin{array}{c}\text { Portfolio } \\
\text { size }\end{array}$ & $\begin{array}{l}\text { Issuer } \\
\text { rating }\end{array}$ & $\begin{array}{c}\text { Portfolio } \\
\text { size }\end{array}$ \\
\hline Mean & 17.51 & 50.20 & 2.03 & 410.78 & 1.95 & 55.69 \\
\hline Median & 18.00 & 34.50 & 2.00 & 447.94 & 2.00 & 55.50 \\
\hline Minimum & 14.00 & 1.00 & 1.00 & 91.17 & 1.00 & 17.00 \\
\hline 25th percentile & 18.00 & 17.00 & 1.98 & 286.33 & 1.00 & 48.75 \\
\hline 75th percentile & 18.00 & 73.00 & 2.15 & 514.94 & 2.00 & 64.00 \\
\hline Maximum & 19.00 & 189.00 & 3.35 & 670.75 & 3.00 & 76.00 \\
\hline
\end{tabular}

Table B.II: Further bond event study specifications.

This table shows the specifications of portfolios used for the bond event study. The portfolio bonds are allocated to the portfolios according to their term to maturity and rating. The six rating categories are Aaa-Aa, A, Baa, Ba, B, and Below B, and the three maturity categories are below the first maturity tertile $(O l d)$, between the first and the second maturity tertile (Intermediate), and above the second maturity tertile (Young). Panel A shows the average number of bonds in the matched portfolios during the event. The term to maturity tertiles are calculated on a daily basis and are shown in Panel B and correspond to the number of years until the bond matures. Panel $\mathrm{C}$ assigns the firm bonds to their respective matched portfolio and shows the number of firm bonds during the event for every matching portfolio.

\begin{tabular}{|c|c|c|c|c|c|c|}
\hline & Aaa-Aa & A & Baa & $\mathrm{Ba}$ & $\mathrm{B}$ & Below B \\
\hline \multicolumn{7}{|c|}{ Panel A: Average portfolio size } \\
\hline Old & 451.39 & 506.05 & 182.32 & 43.59 & & \\
\hline Intermediate & 442.64 & 508.47 & 188.99 & 45.38 & & \\
\hline Young & 428.08 & 513.27 & 191.72 & 47.92 & 34.22 & 7.00 \\
\hline \multicolumn{7}{|c|}{ Panel B: Term to maturity's average tertiles for portfolio selection (Years) } \\
\hline 1st tertile & 2.33 & 2.22 & 2.38 & 2.34 & 3.71 & 2.94 \\
\hline 2nd tertile & 4.99 & 4.77 & 4.79 & 4.92 & 5.68 & 8.80 \\
\hline \multicolumn{7}{|c|}{ Panel C: Distribution of firm bonds } \\
\hline Old & 228 & 2511 & 263 & 46 & & \\
\hline Intermediate & 206 & 2798 & 184 & 13 & & \\
\hline Young & 356 & 4799 & 670 & 76 & 18 & 8 \\
\hline
\end{tabular}




\section{Online Appendix C: Additional cross-sectional analyses}

Table C.I: Estimation of regressions of resolution type-specific variables on abnormal returns.

This table shows the coefficients and robust $t$-statistics (in parentheses) obtained through an ordinary least squares estimation using the average abnormal return of the event day $A R_{0}$ as the dependent variable. Models I to IX include binary variables which are equal to one if the respective settlement type is used, and zero otherwise. TThe company-specific variables include the variable $l g($ Assets) which is equal to the common logarithm of the bank's total assets in million US dollars at the end of the year prior to the settlement. The variable Volatility accounts for the recent six-month stock volatility. The variable Cash flow measures the size of a banks' cash flows divided by its market value and Net income measures its profitability through the ratio of a banks' net income divided by its market value. Both variables relate to the end of the year prior to the event. The case-specific variables include $R M P$, the relative monetary penalty, which represents the sum of all settlement-related monetary penalties divided by the bank's market value six month prior to the settlement. Redundant is a binary variable which equals one if there are more than one settlement resolved on the announcement day, and zero otherwise. The variable Additional RMP corresponds to the relative monetary penalties of any additional settlements that are resolved the same day, excluding the monetary penalty of the settlement considered. Redundant is a binary variable which equals one if more than one settlement is announced at the same time, and zero otherwise. The variable Crime is equal to one if a criminal prosecution is settled, and zero otherwise. US is an additional binary variable that is equal to one if a plaintiff or regulator, respectively, is from the US, and zero otherwise. The variable Crisis is equal to one in case the resolution announcement lies between 2007 and 2011 , and zero otherwise. ${ }^{* * *},{ }^{* * *}$ denote statistical significance at the $10 \%, 5 \%$, and $1 \%$ level, respectively.

\begin{tabular}{|c|c|c|c|c|c|c|c|c|c|}
\hline & \multicolumn{9}{|c|}{$\mathrm{AR}_{0}$} \\
\hline & $\mathrm{I}$ & II & III & IV & $\mathrm{V}$ & VI & VII & VIII & IX \\
\hline Resolution-specific & & & & & & & & & \\
\hline Regulatory fine settlement & $\begin{array}{c}0.02 \\
(0.12)\end{array}$ & & & & & & & & \\
\hline Regulatory fine order & & $\begin{array}{c}-1.00 \\
(-1.29)\end{array}$ & & & & & & & \\
\hline Public settlement & & & $\begin{array}{c}0.02 \\
(0.10)\end{array}$ & & & & & & \\
\hline Plea agreement & & & & $\begin{array}{c}0.83 \\
(1.54)\end{array}$ & & & & & \\
\hline Non-pros. agreement & & & & & $\begin{array}{l}-0.98^{* * *} \\
(-3.02)\end{array}$ & & & & \\
\hline Def. pros. agreement & & & & & & $\begin{array}{c}-0.59 \\
(-1.57)\end{array}$ & & & \\
\hline Interfirm settlement & & & & & & & $\begin{array}{c}0.65 \\
(1.38)\end{array}$ & & \\
\hline Individual settlement & & & & & & & & $\begin{array}{c}0.30 \\
(0.39)\end{array}$ & \\
\hline Class action settlement & & & & & & & & & $\begin{array}{c}-0.13 \\
(-0.74)\end{array}$ \\
\hline Company-specific & & & & & & & & & \\
\hline $\lg$ (Assets) & $\begin{array}{l}-0.61 * * * \\
(-2.75)\end{array}$ & $\begin{array}{l}-0.62^{* * *} \\
(-2.80)\end{array}$ & $\begin{array}{l}-0.61^{* * *} \\
(-2.78)\end{array}$ & $\begin{array}{l}-0.60^{* * *} \\
(-2.74)\end{array}$ & $\begin{array}{l}-0.61^{* * *} \\
(-2.79)\end{array}$ & $\begin{array}{l}-0.66^{* * *} \\
(-2.89)\end{array}$ & $\begin{array}{l}-0.64 * * * \\
(-2.97)\end{array}$ & $\begin{array}{l}-0.61^{* * *} \\
(-2.76)\end{array}$ & $\begin{array}{l}-0.59 * * * \\
(-2.71)\end{array}$ \\
\hline Volatility & $\begin{array}{l}0.33^{* * *} \\
(3.99)\end{array}$ & $\begin{array}{l}0.33^{* * *} \\
(4.00)\end{array}$ & $\begin{array}{l}0.33^{* * *} \\
(3.92)\end{array}$ & $\begin{array}{l}0.33^{* * *} \\
(3.94)\end{array}$ & $\begin{array}{l}0.32^{* * *} \\
(3.87)\end{array}$ & $\begin{array}{l}0.33^{* * *} \\
(3.94)\end{array}$ & $\begin{array}{l}0.33^{* * *} \\
(4.03)\end{array}$ & $\begin{array}{l}0.33^{* * *} \\
(3.96)\end{array}$ & $\begin{array}{l}0.33^{* * *} \\
(3.90)\end{array}$ \\
\hline Cash flow & $\begin{array}{c}0.01 \\
(1.06)\end{array}$ & $\begin{array}{c}0.01 \\
(1.14)\end{array}$ & $\begin{array}{c}0.01 \\
(1.06)\end{array}$ & $\begin{array}{c}0.01 \\
(1.18)\end{array}$ & $\begin{array}{c}0.01 \\
(1.06)\end{array}$ & $\begin{array}{c}0.01 \\
(1.22)\end{array}$ & $\begin{array}{c}0.01 \\
(1.04)\end{array}$ & $\begin{array}{c}0.01 \\
(1.06)\end{array}$ & $\begin{array}{c}0.01 \\
(1.02)\end{array}$ \\
\hline Net income & $\begin{array}{c}0.00 \\
(0.32)\end{array}$ & $\begin{array}{c}0.00 \\
(0.55)\end{array}$ & $\begin{array}{c}0.00 \\
(0.30)\end{array}$ & $\begin{array}{c}0.00 \\
(0.27)\end{array}$ & $\begin{array}{c}0.00 \\
(0.39)\end{array}$ & $\begin{array}{c}0.00 \\
(0.18)\end{array}$ & $\begin{array}{c}0.00 \\
(0.25)\end{array}$ & $\begin{array}{c}0.00 \\
(0.29)\end{array}$ & $\begin{array}{c}0.00 \\
(0.28)\end{array}$ \\
\hline Case-specific & & & & & & & & & \\
\hline $\mathrm{RMP}$ & $\begin{array}{l}0.14^{* * *} \\
(4.84)\end{array}$ & $\begin{array}{l}0.14^{* * *} \\
(4.80)\end{array}$ & $\begin{array}{l}0.14^{* * *} \\
(4.80)\end{array}$ & $\begin{array}{l}0.13^{* * *} \\
(4.70)\end{array}$ & $\begin{array}{l}0.14^{* * *} \\
(4.83)\end{array}$ & $\begin{array}{l}0.14^{* * *} \\
(4.81)\end{array}$ & $\begin{array}{l}0.14^{* * *} \\
(4.96)\end{array}$ & $\begin{array}{l}0.14^{* * *} \\
(4.84)\end{array}$ & $\begin{array}{l}0.14^{* * *} \\
(4.74)\end{array}$ \\
\hline Addition. RMP & $\begin{array}{l}0.38^{* * *} \\
(9.18)\end{array}$ & $\begin{array}{l}0.38^{* * *} \\
(9.58)\end{array}$ & $\begin{array}{l}0.37^{* * *} \\
(8.56)\end{array}$ & $\begin{array}{l}0.38^{* * *} \\
(9.66)\end{array}$ & $\begin{array}{l}0.38^{* * *} \\
(9.50)\end{array}$ & $\begin{array}{l}0.37^{* * *} \\
(9.12)\end{array}$ & $\begin{array}{l}0.38^{* * *} \\
(9.52)\end{array}$ & $\begin{array}{l}0.37^{* * *} \\
(9.49)\end{array}$ & $\begin{array}{l}0.37^{* * *} \\
(9.34)\end{array}$ \\
\hline Redund. & $\begin{array}{c}-0.26 \\
(-1.24)\end{array}$ & $\begin{array}{c}-0.27 \\
(-1.37)\end{array}$ & $\begin{array}{c}-0.25 \\
(-1.22)\end{array}$ & $\begin{array}{c}-0.33 \\
(-1.62)\end{array}$ & $\begin{array}{c}-0.26 \\
(-1.28)\end{array}$ & $\begin{array}{c}-0.20 \\
(-0.96)\end{array}$ & $\begin{array}{c}-0.21 \\
(-1.07)\end{array}$ & $\begin{array}{c}-0.25 \\
(-1.24)\end{array}$ & $\begin{array}{c}-0.28 \\
(-1.36)\end{array}$ \\
\hline US & $\begin{array}{c}0.08 \\
(0.29)\end{array}$ & $\begin{array}{c}-0.03 \\
(-0.15)\end{array}$ & $\begin{array}{c}0.06 \\
(0.26)\end{array}$ & $\begin{array}{c}0.05 \\
(0.21)\end{array}$ & $\begin{array}{c}0.07 \\
(0.31)\end{array}$ & $\begin{array}{c}0.09 \\
(0.41)\end{array}$ & $\begin{array}{c}0.09 \\
(0.44)\end{array}$ & $\begin{array}{c}0.07 \\
(0.32)\end{array}$ & $\begin{array}{c}0.10 \\
(0.44)\end{array}$ \\
\hline Crisis & $\begin{array}{c}0.09 \\
(0.37)\end{array}$ & $\begin{array}{c}0.13 \\
(0.54)\end{array}$ & $\begin{array}{c}0.09 \\
(0.36)\end{array}$ & $\begin{array}{c}0.09 \\
(0.40)\end{array}$ & $\begin{array}{c}0.12 \\
(0.49)\end{array}$ & $\begin{array}{c}0.07 \\
(0.31)\end{array}$ & $\begin{array}{c}0.07 \\
(0.30)\end{array}$ & $\begin{array}{c}0.09 \\
(0.37)\end{array}$ & $\begin{array}{c}0.08 \\
(0.33)\end{array}$ \\
\hline Constant & $\begin{array}{l}3.80^{* *} \\
(2.34)\end{array}$ & $\begin{array}{l}3.97^{* *} \\
(2.47)\end{array}$ & $\begin{array}{l}3.82^{* *} \\
(2.38)\end{array}$ & $\begin{array}{l}3.80^{* *} \\
(2.36)\end{array}$ & $\begin{array}{l}3.87^{* *} \\
(2.41)\end{array}$ & $\begin{array}{l}4.21^{* *} \\
(2.52)\end{array}$ & $\begin{array}{l}4.01^{* *} \\
(2.54)\end{array}$ & $\begin{array}{l}3.82^{* *} \\
(2.37)\end{array}$ & $\begin{array}{l}3.73^{* *} \\
(2.33)\end{array}$ \\
\hline Observations & 315 & 315 & 315 & 315 & 315 & 315 & 315 & 315 & 315 \\
\hline$R^{2}$ & 0.26 & 0.27 & 0.26 & 0.26 & 0.26 & 0.26 & 0.27 & 0.26 & 0.26 \\
\hline Adjusted $R^{2}$ & 0.23 & 0.24 & 0.23 & 0.24 & 0.24 & 0.24 & 0.25 & 0.23 & 0.24 \\
\hline F-value & $20.16^{* * *}$ & $20.52^{* * *}$ & $20.19^{* * *}$ & $21.12^{* * *}$ & $20.92^{* * *}$ & $20.07 * * *$ & $20.30^{* * *}$ & $20.26^{* * *}$ & $20.27 * * *$ \\
\hline
\end{tabular}


Table C.II: Estimation of regressions of plaintiff-specific variables on abnormal returns.

This table shows the coefficients and robust $t$-statistics (in parentheses) obtained through an ordinary least squares estimation using the average abnormal return of the event day $A R_{0}$ as the dependent variable. Models I to XII include binary variables which are equal to one if the settlement is reached with the respective plaintiff, and zero otherwise. The company-specific variables include the variable $l g(A s s e t s)$ which is equal to the common logarithm of the bank's total assets in million US dollars at the end of the year prior to the settlement. The variable Volatility accounts for the recent six-month stock volatility. The variable Cash flow measures the size of a banks' cash flows divided by its market value and Net income measures its profitability through the ratio of a banks' net income divided by its market value. Both variables relate to the end of the year prior to the event. The case-specific variables include $R M P$, the relative monetary penalty, which represents the sum of all settlement-related monetary penalties divided by the bank's market value six month prior to the settlement. Redundant is a binary variable which equals one if there are more than one settlement resolved on the announcement day, and zero otherwise. The variable Additional RMP corresponds to the relative monetary penalties of any additional settlements that are resolved the same day, excluding the monetary penalty of the settlement considered. Redundant is a binary variable which equals one if more than one settlement is announced at the same time, and zero otherwise. The variable Crime is equal to one if a criminal prosecution is settled, and zero otherwise. US is an additional binary variable that is equal to one if a plaintiff or regulator, respectively, is from the US, and zero otherwise. The variable Crisis is equal to one in case the resolution announcement lies between 2007 and 2011 , and zero otherwise. ${ }^{*},{ }^{* *},{ }^{* *}$ denote statistical significance at the $10 \%, 5 \%$, and $1 \%$ level, respectively.

\begin{tabular}{|c|c|c|c|c|c|c|c|c|c|c|c|c|}
\hline & \multicolumn{12}{|c|}{$\mathrm{AR}_{0}$} \\
\hline & $\mathrm{I}$ & II & III & IV & $\mathrm{V}$ & VI & VII & VIII & IX & $\mathrm{X}$ & $\mathrm{XI}$ & XII \\
\hline $\begin{array}{l}\text { Plaintiff-specific } \\
\text { DOJ }\end{array}$ & $\begin{array}{c}0.56^{*} \\
(1.75)\end{array}$ & & & & & & & & & & & \\
\hline Investors & & $\begin{array}{c}0.03 \\
(0.12)\end{array}$ & & & & & & & & & & \\
\hline State DOJ & & & $\begin{array}{l}-0.22 \\
(-0.63)\end{array}$ & & & & & & & & & \\
\hline FHFA & & & & $\begin{array}{l}-0.20 \\
(-0.72)\end{array}$ & & & & & & & & \\
\hline $\mathrm{OCC}$ & & & & & $\begin{array}{l}-0.68^{* * *} \\
(-2.72)\end{array}$ & & & & & & & \\
\hline FRB & & & & & & $\begin{array}{l}-0.36 \\
(-0.86)\end{array}$ & & & & & & \\
\hline FCA & & & & & & & $\begin{array}{l}-0.31 \\
(-0.85)\end{array}$ & & & & & \\
\hline SEC & & & & & & & & $\begin{array}{l}-0.03 \\
(-0.11)\end{array}$ & & & & \\
\hline CFTC & & & & & & & & & $\begin{array}{c}0.11 \\
(0.30)\end{array}$ & & & \\
\hline EU Commission & & & & & & & & & & $\begin{array}{c}0.29 \\
(1.03)\end{array}$ & & \\
\hline Consumers & & & & & & & & & & & $\begin{array}{c}0.26 \\
(0.67)\end{array}$ & \\
\hline FINRA & & & & & & & & & & & & $\begin{array}{c}0.35 \\
(1.18)\end{array}$ \\
\hline $\begin{array}{l}\text { Company-specific } \\
\lg \text { (Assets) }\end{array}$ & $\begin{array}{l}-0.66^{* * *} \\
(-2.88)\end{array}$ & $\begin{array}{c}{ }^{*}-0.63^{* * *} \\
(-2.82)\end{array}$ & $\begin{array}{l}-0.63^{* * *} \\
(-2.79)\end{array}$ & $\begin{array}{l}-0.63^{* * *} \\
(-2.79)\end{array}$ & $\begin{array}{l}-0.59^{* *} \\
(-2.58)\end{array}$ & $\begin{array}{l}-0.65 * * * \\
(-2.85)\end{array}$ & $\begin{array}{c}{ }^{*}-0.64^{* * *} \\
(-2.82)\end{array}$ & $\begin{array}{c}-0.63^{* * *} \\
(-2.78)\end{array}$ & $\begin{array}{c}*-0.62^{* * *} \\
(-2.76)\end{array}$ & $\begin{array}{c}{ }^{k}-0.63^{* * *} \\
(-2.80)\end{array}$ & $\begin{array}{c}*-0.64^{* * *} \\
(-2.81)\end{array}$ & $\begin{array}{c}*-0.61^{* * *} \\
(-2.73)\end{array}$ \\
\hline Volatility & $\begin{array}{l}0.30^{* * *} \\
(3.74)\end{array}$ & $\begin{array}{l}\text { * } 0.33^{* * *} \\
(3.87)\end{array}$ & $\begin{array}{l}0.33^{* * *} \\
(3.95)\end{array}$ & $\begin{array}{l}0.32^{* * *} \\
(3.83)\end{array}$ & $\begin{array}{l}0.33^{* * * *} \\
(3.90)\end{array}$ & $\begin{array}{l}0.33^{* * *} \\
(3.97)\end{array}$ & $\begin{array}{l}\text { * } 0.33^{* * * *} \\
(3.92)\end{array}$ & $\begin{array}{l}{ }^{*} 0.33^{* * *} \\
(3.91)\end{array}$ & $\begin{array}{l}* 0.33^{* * *} \\
(3.91)\end{array}$ & $\begin{array}{l}k^{*} \\
0.33^{* * *} \\
(3.93)\end{array}$ & $\begin{array}{l}* .32^{* * *} \\
(3.89)\end{array}$ & $\begin{array}{l}* \quad 0.33^{* * *} \\
(3.99)\end{array}$ \\
\hline Cash flow & $\begin{array}{c}0.01 \\
(1.08)\end{array}$ & $\begin{array}{c}0.01 \\
(1.08)\end{array}$ & $\begin{array}{c}0.01 \\
(1.08)\end{array}$ & $\begin{array}{c}0.01 \\
(1.09)\end{array}$ & $\begin{array}{c}0.00 \\
(0.89)\end{array}$ & $\begin{array}{c}0.01 \\
(1.08)\end{array}$ & $\begin{array}{c}0.01 \\
(1.06)\end{array}$ & $\begin{array}{c}0.01 \\
(1.08)\end{array}$ & $\begin{array}{c}0.01 \\
(1.08)\end{array}$ & $\begin{array}{c}0.01 \\
(1.01)\end{array}$ & $\begin{array}{c}0.01 \\
(1.03)\end{array}$ & $\begin{array}{c}0.01 \\
(1.06)\end{array}$ \\
\hline Net income & $\begin{array}{c}0.00 \\
(0.19)\end{array}$ & $\begin{array}{c}0.00 \\
(0.30)\end{array}$ & $\begin{array}{c}0.00 \\
(0.29)\end{array}$ & $\begin{array}{c}0.00 \\
(0.26)\end{array}$ & $\begin{array}{c}0.00 \\
(0.47)\end{array}$ & $\begin{array}{c}0.00 \\
(0.32)\end{array}$ & $\begin{array}{c}0.00 \\
(0.27)\end{array}$ & $\begin{array}{c}0.00 \\
(0.29)\end{array}$ & $\begin{array}{c}0.00 \\
(0.33)\end{array}$ & $\begin{array}{c}0.00 \\
(0.32)\end{array}$ & $\begin{array}{c}0.00 \\
(0.30)\end{array}$ & $\begin{array}{c}0.00 \\
(0.21)\end{array}$ \\
\hline Case-specific & & & & & & & & & & & & \\
\hline RMP & $\begin{array}{l}0.13^{* * *} \\
(4.88)\end{array}$ & $\begin{array}{l}0.14^{* * * *} \\
(4.74)\end{array}$ & $\begin{array}{l}0.14^{* * *} \\
(5.08)\end{array}$ & $\begin{array}{l}0.14^{* * * *} \\
(4.69)\end{array}$ & $\begin{array}{l}0.14^{* * * *} \\
(4.73)\end{array}$ & $\begin{array}{l}0.14^{* * * *} \\
(4.79)\end{array}$ & $\begin{array}{l}0.14^{* * *} \\
(4.75)\end{array}$ & $\begin{array}{l}0.14^{* * * *} \\
(4.76)\end{array}$ & $\begin{array}{l}0.14^{* * *} \\
(4.77)\end{array}$ & $\begin{array}{l}0.14^{* * *} \\
(4.74)\end{array}$ & $\begin{array}{l}0.14^{* * *} \\
(4.80)\end{array}$ & $\begin{array}{l}0.14^{* * *} \\
(4.80)\end{array}$ \\
\hline Addition. RMP & $\begin{array}{l}0.38^{* * *} \\
(9.58)\end{array}$ & $\begin{array}{c}0.37^{* * *} \\
(9.11)\end{array}$ & $\begin{array}{l}0.37^{* * *} \\
(9.19)\end{array}$ & $\begin{array}{l}0.37^{* * *} \\
(9.15)\end{array}$ & $\begin{array}{l}0.36^{* * *} \\
(8.97)\end{array}$ & $\begin{array}{l}0.37^{* * *} \\
(9.43)\end{array}$ & $\begin{array}{l}0.37^{* * *} \\
(9.18)\end{array}$ & $\begin{array}{l}0.37^{* * *} \\
(9.13)\end{array}$ & $\begin{array}{l}0.37^{* * *} \\
(8.78)\end{array}$ & $\begin{array}{l}0.37^{* * *} \\
(9.27)\end{array}$ & $\begin{array}{l}0.37^{* * *} \\
(9.16)\end{array}$ & $\begin{array}{l}* 0.37^{* * *} \\
(9.16)\end{array}$ \\
\hline Redund. & $\begin{array}{l}-0.24 \\
(-1.15)\end{array}$ & $\begin{array}{l}-0.21 \\
(-1.01)\end{array}$ & $\begin{array}{l}-0.21 \\
(-0.99)\end{array}$ & $\begin{array}{l}-0.23 \\
(-1.07)\end{array}$ & $\begin{array}{l}-0.18 \\
(-0.84)\end{array}$ & $\begin{array}{l}-0.18 \\
(-0.84)\end{array}$ & $\begin{array}{c}-0.20 \\
(-0.92)\end{array}$ & $\begin{array}{c}-0.22 \\
(-1.03)\end{array}$ & $\begin{array}{c}-0.23 \\
(-1.01)\end{array}$ & $\begin{array}{c}-0.21 \\
(-0.99)\end{array}$ & $\begin{array}{c}-0.21 \\
(-0.96)\end{array}$ & $\begin{array}{c}-0.20 \\
(-0.96)\end{array}$ \\
\hline Crime & $\begin{array}{c}-0.64 \\
(-1.47)\end{array}$ & $\begin{array}{c}-0.16 \\
(-0.48)\end{array}$ & $\begin{array}{l}-0.19 \\
(-0.55)\end{array}$ & $\begin{array}{l}-0.17 \\
(-0.51)\end{array}$ & $\begin{array}{l}-0.15 \\
(-0.46)\end{array}$ & $\begin{array}{l}-0.21 \\
(-0.61)\end{array}$ & $\begin{array}{c}-0.18 \\
(-0.52)\end{array}$ & $\begin{array}{c}-0.17 \\
(-0.49)\end{array}$ & $\begin{array}{c}-0.15 \\
(-0.43)\end{array}$ & $\begin{array}{c}-0.17 \\
(-0.49)\end{array}$ & $\begin{array}{c}-0.16 \\
(-0.48)\end{array}$ & $\begin{array}{c}-0.15 \\
(-0.45)\end{array}$ \\
\hline US & $\begin{array}{c}0.05 \\
(0.20)\end{array}$ & $\begin{array}{c}0.07 \\
(0.33)\end{array}$ & $\begin{array}{c}0.09 \\
(0.40)\end{array}$ & $\begin{array}{c}0.09 \\
(0.39)\end{array}$ & $\begin{array}{c}0.10 \\
(0.46)\end{array}$ & $\begin{array}{c}0.10 \\
(0.43)\end{array}$ & $\begin{array}{c}-0.07 \\
(-0.22)\end{array}$ & $\begin{array}{c}0.08 \\
(0.36)\end{array}$ & $\begin{array}{c}0.07 \\
(0.30)\end{array}$ & $\begin{array}{c}0.15 \\
(0.55)\end{array}$ & $\begin{array}{c}0.07 \\
(0.30)\end{array}$ & $\begin{array}{c}0.06 \\
(0.28)\end{array}$ \\
\hline Crisis & $\begin{array}{c}0.12 \\
(0.53)\end{array}$ & $\begin{array}{c}0.09 \\
(0.37)\end{array}$ & $\begin{array}{c}0.11 \\
(0.44)\end{array}$ & $\begin{array}{c}0.08 \\
(0.34)\end{array}$ & $\begin{array}{c}0.09 \\
(0.37)\end{array}$ & $\begin{array}{c}0.07 \\
(0.31)\end{array}$ & $\begin{array}{c}0.09 \\
(0.37)\end{array}$ & $\begin{array}{c}0.09 \\
(0.38)\end{array}$ & $\begin{array}{c}0.09 \\
(0.37)\end{array}$ & $\begin{array}{c}0.11 \\
(0.44)\end{array}$ & $\begin{array}{c}0.10 \\
(0.41)\end{array}$ & $\begin{array}{c}0.06 \\
(0.26)\end{array}$ \\
\hline Constant & $\begin{array}{l}4.21^{* *} \\
(2.54)\end{array}$ & $\begin{array}{l}3.96^{* *} \\
(2.43)\end{array}$ & $\begin{array}{c}3.95^{* *} \\
(2.41)\end{array}$ & $\begin{array}{l}3.98^{* *} \\
(2.42)\end{array}$ & $\begin{array}{c}3.68^{* *} \\
(2.22)\end{array}$ & $\begin{array}{l}4.08^{* *} \\
(2.47)\end{array}$ & $\begin{array}{l}4.16^{* *} \\
(2.49)\end{array}$ & $\begin{array}{l}3.96^{* *} \\
(2.41)\end{array}$ & $\begin{array}{l}3.94^{* *} \\
(2.40)\end{array}$ & $\begin{array}{c}3.93^{* *} \\
(2.39)\end{array}$ & $\begin{array}{c}4.03^{* *} \\
(2.44)\end{array}$ & $\begin{array}{l}3.85^{* *} \\
(2.35)\end{array}$ \\
\hline Observations & 315 & 315 & 315 & 315 & 315 & 315 & 315 & 315 & 315 & 315 & 315 & 315 \\
\hline$R^{2}$ & 0.27 & 0.26 & 0.26 & 0.26 & 0.27 & 0.26 & 0.26 & 0.26 & 0.26 & 0.26 & 0.26 & 0.26 \\
\hline Adjusted $R^{2}$ & 0.24 & 0.23 & 0.23 & 0.23 & 0.24 & 0.23 & 0.23 & 0.23 & 0.23 & 0.23 & 0.23 & 0.23 \\
\hline F-value & $19.64^{* * *}$ & * $17.99 * * *$ & $18.67^{* * *}$ & $17.98^{* * *}$ & $19.04 * * *$ & $19.17^{* * * *}$ & * $18.24^{* * *}$ & * $17.98^{* * * *}$ & * $18.07 * * *$ & k $18.21 * * *$ & * $18.07^{* * *}$ & * $18.24^{* * *}$ \\
\hline
\end{tabular}




\section{Online Appendix D: Event study subsample analyses}

Table D.I: Stock subsample event study results.

This table shows the stock event study results. Daily abnormal returns are calculated using a market model event study, the value-weighted Datastream domestic index as the benchmark index, and a 252-day estimation period ending 11 days prior to the event day. In order to examine short-term wealth effects, the average abnormal returns on days $t=-1, t=0$, and $t=+1$, are calculated, as well as the average cumulative abnormal returns (ACARs) during the asymmetric short-term event windows $[-1 ; 0]$ and $[0 ;+1]$ to capture anticipated and lagged price adjustments. As parametric test statistics, the $t$-test and the variance-change corrected standardized cross-section test introduced by Boehmer et al. (1991), the BMP-test are used. Furthermore, significance is also tested using the nonparametric the Wilcoxon signed rank test and the nonparametric rank test first introduced by Corrado (1989) and later refined by Corrado and Zivney (1992), the CZ-test. Panels A and B split the sample according to plaintiff nationality and Panels $\mathrm{C}$ and $\mathrm{D}$ according to banks' debt-to-capital value. The cut-offs for low and high debt-to-capital values are the 25 th and 75 th percentiles. Panels E and F report the differences between the ACARs and the median CARs as well as the statistics of two sample comparison tests, i. e., Welch's $t$-test and the non-parametric Wilcoxon-Mann-Whitney $U$-test. ${ }^{*},{ }^{* *},{ }^{* * *}$ denote statistical significance at the $10 \%, 5 \%$, and $1 \%$ level, respectively.

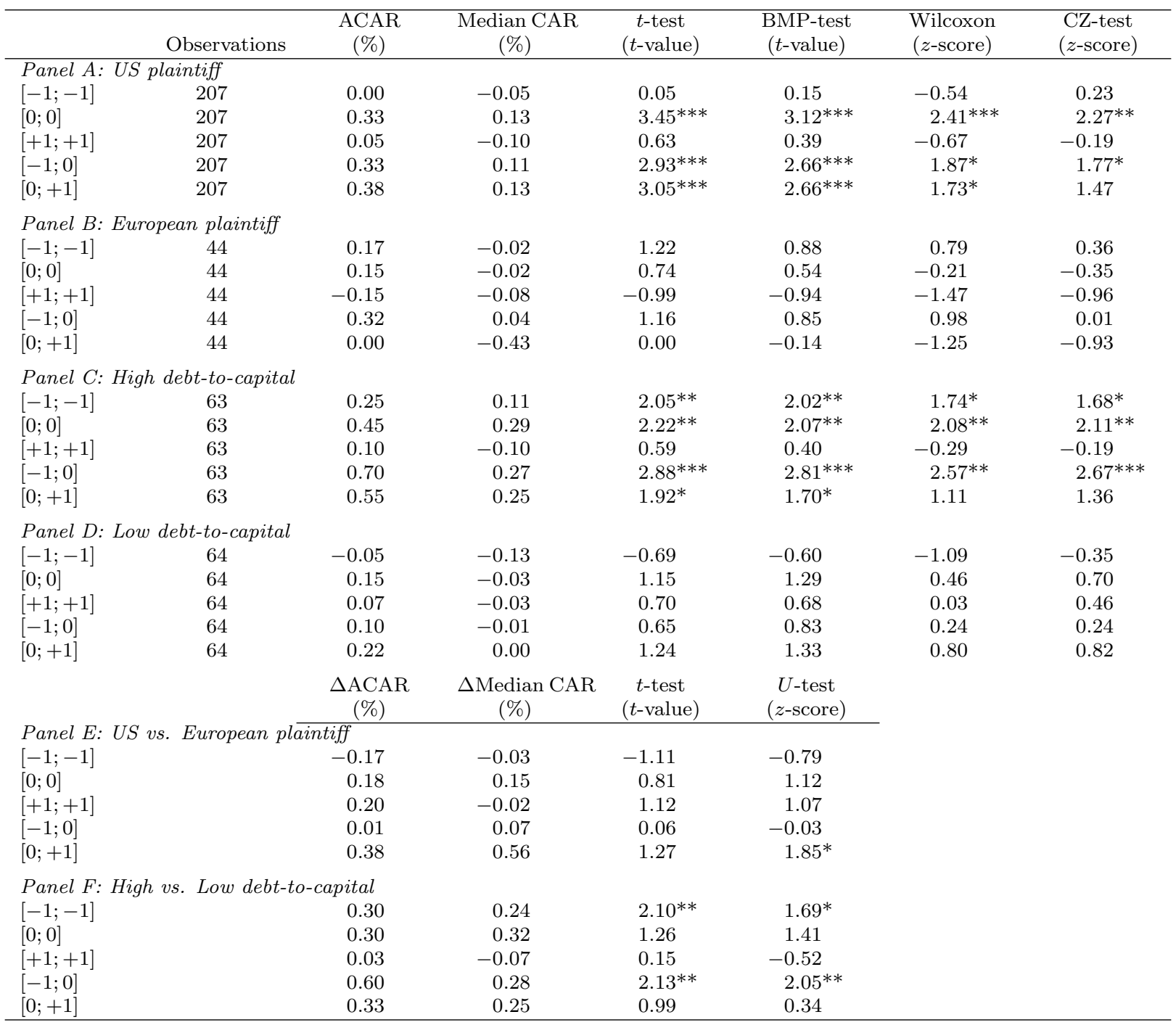


Table D.II: Bond subsample event study results.

This table shows the results of our bond event study. Expected bond returns are calculated using the matching portfolio model. The bonds are allocated to the portfolios according to three term to maturity classes and six rating classes. To condense the abnormal bond returns of all bonds a certain bank has outstanding into one abnormal bond return, the value-weighted firm level approach is used. In order to examine short-term wealth effects, the average abnormal bond returns on days $t=-1$, $t=0$, and $t=+1$ are calculated, as well as the average cumulative abnormal bond returns (ACABRs) during the asymmetric short-term event windows $[-1 ; 0]$ and $[0 ;+1]$ to capture anticipated and lagged price adjustments. To evaluate the statistical significance of the abnormal returns, the parametric standardized and unstandardized $t$-tests and nonparametric Wilcoxon signed rank tests are used. Abnormal bond returns are standardized with their estimated standard deviation during the time frame $[-10 ;+10]$, excluding the short-term window $[-1 ;+1]$.Panels A and B split the sample according to plaintiff nationality and Panels C and D according to banks' debt-to-capital value. The cut-offs for low and high debt-to-capital values are the 25th and 75th percentiles. Panels E and F report the differences between the ACABRs and the median CABRs as well as the statistics of two sample comparison tests, i. e., Welch's $t$-test and the non-parametric Wilcoxon-Mann-Whitney $U$-test. ${ }^{*},{ }^{* *},{ }^{* * *}$ denote statistical significance at the $10 \%, 5 \%$, and $1 \%$ level, respectively.

\begin{tabular}{|c|c|c|c|c|c|c|c|}
\hline & Observations & $\begin{array}{l}\text { ACABR } \\
\text { (bps) }\end{array}$ & $\begin{array}{l}\text { Median CABR } \\
\text { (bps) }\end{array}$ & $\begin{array}{c}t \text {-test } \\
(t \text {-value })\end{array}$ & $\begin{array}{l}\text { Wilcoxon } \\
(z \text {-score })\end{array}$ & $\begin{array}{c}\text { Std. } t \text {-test } \\
(t \text {-value })\end{array}$ & $\begin{array}{l}\text { Std. Wilcoxon } \\
(z \text {-score })\end{array}$ \\
\hline \multicolumn{8}{|c|}{ Panel A: US plaintiff } \\
\hline$[-1 ;-1]$ & 207 & -0.64 & -0.66 & -0.78 & -0.98 & -0.89 & -1.02 \\
\hline$[0 ; 0]$ & 207 & 0.23 & 0.15 & 0.30 & 0.36 & 0.63 & 0.54 \\
\hline$[+1 ;+1]$ & 207 & 1.39 & 0.56 & 1.61 & 1.63 & $1.86^{*}$ & 1.59 \\
\hline$[-1 ; 0]$ & 207 & -0.41 & -0.99 & -0.37 & -0.38 & -0.14 & -0.49 \\
\hline$[0 ;+1]$ & 207 & 1.62 & 1.72 & 1.27 & 1.56 & $1.70^{*}$ & $1.83^{*}$ \\
\hline \multicolumn{8}{|c|}{ Panel B: European plaintiff } \\
\hline$[-1 ;-1]$ & 44 & -1.95 & -1.25 & -1.25 & -1.06 & -1.10 & -1.39 \\
\hline$[0 ; 0]$ & 44 & 2.20 & 1.06 & 0.77 & $1.91^{*}$ & 1.47 & 1.38 \\
\hline$[+1 ;+1]$ & 44 & 3.65 & 2.17 & 1.23 & $1.65^{*}$ & 1.34 & 1.38 \\
\hline$[-1 ; 0]$ & 44 & 0.25 & 0.03 & 0.06 & 0.75 & 0.49 & 0.27 \\
\hline$[0 ;+1]$ & 44 & 5.84 & 2.51 & $2.55^{* *}$ & $2.32^{* *}$ & $2.00^{*}$ & $1.69^{*}$ \\
\hline \multicolumn{8}{|c|}{ Panel C: High debt-to-capital } \\
\hline$[-1 ;-1]$ & 63 & 1.46 & -0.35 & 0.83 & 0.62 & 0.88 & 0.47 \\
\hline$[0 ; 0]$ & 63 & -2.30 & -0.93 & -1.10 & -1.49 & $-1.78^{*}$ & $-1.65^{*}$ \\
\hline$[+1 ;+1]$ & 63 & 4.76 & 1.45 & $1.84^{*}$ & $1.66^{*}$ & $2.17^{* *}$ & $1.92^{*}$ \\
\hline$[-1 ; 0]$ & 63 & -0.85 & -0.83 & -0.28 & -0.38 & -0.78 & -0.76 \\
\hline$[0 ;+1]$ & 63 & 2.46 & 0.24 & 1.08 & 0.39 & 0.64 & 0.55 \\
\hline \multicolumn{8}{|c|}{ Panel D: Low debt-to-capital } \\
\hline$[-1 ;-1]$ & 64 & -2.23 & -1.32 & $-1.68^{*}$ & -1.38 & -1.36 & -1.30 \\
\hline$[0 ; 0]$ & 64 & -1.64 & -0.78 & -1.25 & -1.00 & -0.96 & -0.57 \\
\hline$[+1 ;+1]$ & 64 & 0.43 & 0.97 & 0.29 & 0.86 & 0.32 & 0.38 \\
\hline$[-1 ; 0]$ & 64 & -3.88 & -2.87 & $-2.05^{* *}$ & $-1.73^{*}$ & -1.56 & $-1.69^{*}$ \\
\hline \multirow[t]{2}{*}[0;+1]{} & 64 & -1.21 & 0.66 & -0.57 & 0.35 & -0.55 & 0.28 \\
\hline & & $\begin{array}{l}\Delta \mathrm{ACABR} \\
(\mathrm{bps})\end{array}$ & $\begin{array}{l}\Delta \text { Median CABR } \\
\quad(\text { bps })\end{array}$ & $\begin{array}{c}t \text {-test } \\
(t \text {-value })\end{array}$ & $\begin{array}{c}U \text {-test } \\
(z \text {-score })\end{array}$ & & \\
\hline \multicolumn{8}{|c|}{ Panel E: US vs. European plaintiff } \\
\hline $\begin{array}{l}{[-1 ;-1]} \\
{[0: 0]}\end{array}$ & & $\begin{array}{r}1.31 \\
-1.97\end{array}$ & 0.59 & 0.68 & $\begin{array}{c}0.50 \\
-168 *\end{array}$ & & \\
\hline$[+1 ;+1]$ & & $\begin{array}{l}-1.97 \\
-2.26\end{array}$ & $\begin{array}{l}-0.91 \\
-1.61\end{array}$ & $\begin{array}{l}-0.91 \\
-0.98\end{array}$ & $\begin{array}{l}-1.688^{2} \\
-0.79\end{array}$ & & \\
\hline$[-1 ; 0]$ & & -0.66 & -1.02 & -0.22 & -1.07 & & \\
\hline$[0 ;+1]$ & & -4.22 & -0.79 & -1.43 & -1.44 & & \\
\hline \multicolumn{8}{|c|}{ Panel F: High vs. Low debt-to-capital } \\
\hline$[-1 ;-1]$ & & 3.69 & 0.97 & $1.68^{*}$ & 1.41 & & \\
\hline$[0 ; 0]$ & & -0.66 & -0.15 & -0.27 & -0.18 & & \\
\hline$[+1 ;+1]$ & & 4.33 & 0.48 & 1.45 & 0.56 & & \\
\hline$[-1 ; 0]$ & & 3.03 & 2.04 & 0.86 & 1.13 & & \\
\hline$[0 ;+1]$ & & 3.67 & -0.42 & 1.18 & -0.11 & & \\
\hline
\end{tabular}


Table D.III: CDS subsample event study results.

This table shows the results of our CDS event study. The five-year senior CDS mid-spread in US dollars is used to calculate abnormal CDS spread changes $(A S C s)$ by adjusting actually observed CDS spread changes by the spread change of a matching portfolio of the same rating class as the event firm. The daily CDS portfolios are computed as the equally weighted crosssectional mean of all 211 banks with available CDS data through Reuters EOD and a long-term issuer rating of Moody's, excluding the event firm. In total, six portfolios are constructed representing the six rating categories Aaa-Aa, A, Baa, Ba, B, and below B. In order to examine short-term wealth effects, the average abnormal spread changes on days $t=-1, t=0$, and $t=+1$ are calculated, as well as the average cumulative abnormal spread changes $(A C A S C s)$ during the asymmetric short-term event windows $[-1 ; 0]$ and $[0 ;+1]$ to capture anticipated and lagged price adjustments. Statistical significance is tested using the parametric $t$-test and the nonparametric Wilcoxon signed-rank test. Panels A and B split the sample according to plaintiff nationality and Panels $\mathrm{C}$ and $\mathrm{D}$ according to banks' debt-to-capital value. The cut-offs for low and high debt-to-capital values are the 25th and 75th percentiles. Panels E and F report the differences between the ACASCs and the median CASCs as well as the statistics of two sample comparison tests, i. e., Welch's $t$-test and the non-parametric Wilcoxon-Mann-Whitney $U$-test. ${ }^{*},{ }^{* *},{ }^{* * *}$ denote statistical significance at the $10 \%, 5 \%$, and $1 \%$ level, respectively.

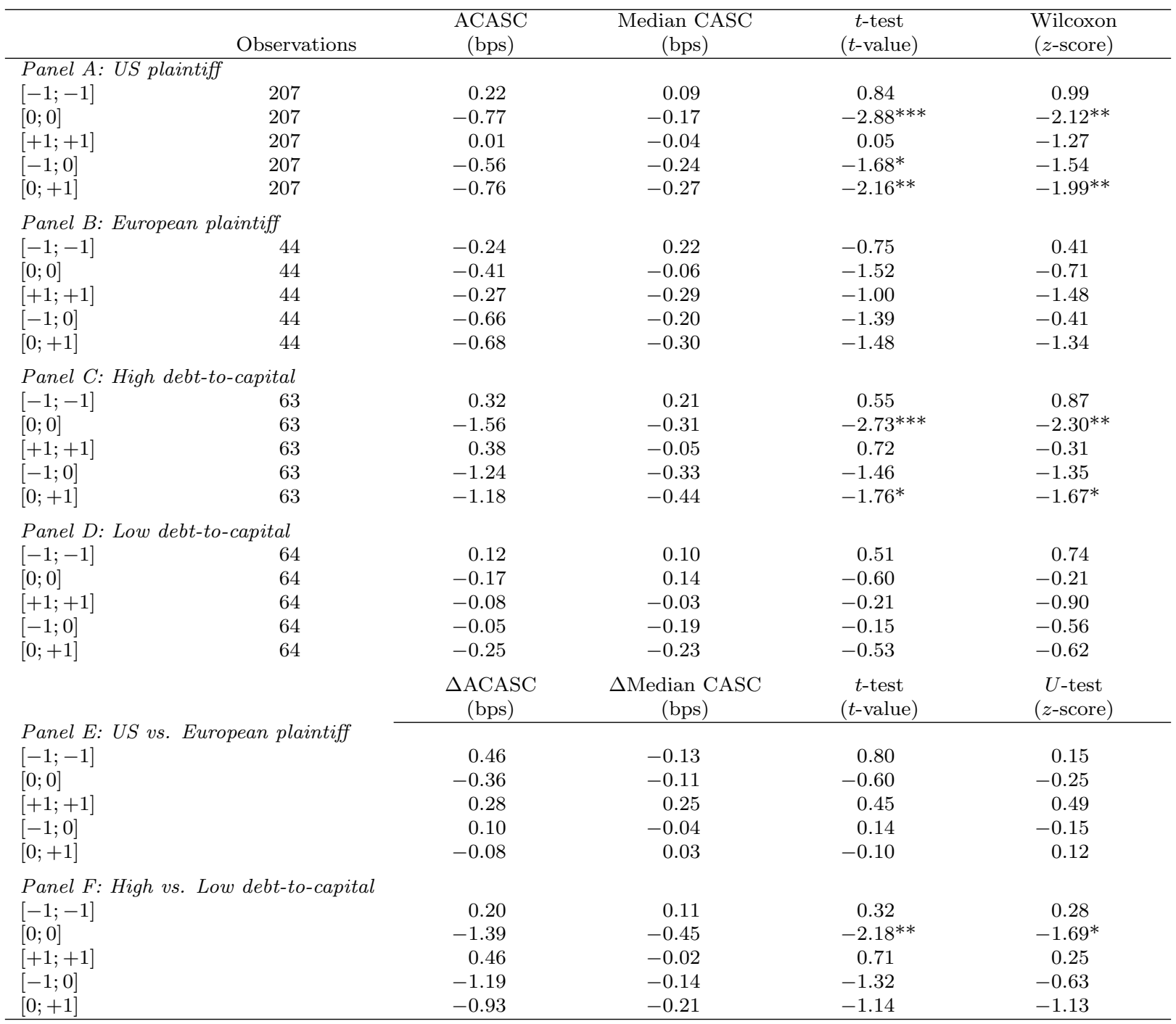




\section{Online Appendix E: Variable sources}

Table E.I: Variable sources.

This table shows the sources of variables used for the empirical analyses. The first column shows the variable name as it is used throughout this study. The second column gives the data item codes that identify the variables in the respective data source, which is given in column four. Column three entails some additional details for the variable. The different panels further structure the variables into into variable that relate to banks' financial statements (Panel $A)$, the stock, bond, and CDS market (Panels B, C, and D), as well as to banks' systemic risk (Panel E).

\begin{tabular}{|c|c|c|c|}
\hline Variable name & Code & Description & Source \\
\hline \multicolumn{4}{|c|}{ Panel A: Financial statement } \\
\hline $\lg$ (Assets) & WC02999 & $\log$ (Total Assets) & Worldscope \\
\hline Cash flow & WC04201 & $\begin{array}{l}\text { Sum of net income and all non-cash charges or credits scaled } \\
\text { by market value }\end{array}$ & Worldscope \\
\hline Net income & WC01651 & Net income before preferred dividends scaled by market value & Worldscope \\
\hline Cash & WC02003 & Cash scaled by market value & Worldscope \\
\hline Revenues & WC01001 & Revenues scaled by market value & Worldscope \\
\hline Debt-to-capital & WC08221 & Total debt scaled by total capital & Worldscope \\
\hline Tier 1 ratio & WC18157 & Ratio of tier 1 capital to total risk-weighted assets & Worldscope \\
\hline Loan growth & WC08666 & Total loans year on year growth rate & Worldscope \\
\hline \multicolumn{4}{|c|}{ Panel B: Stock data } \\
\hline Stock price & RI & The total return index assuming that dividends are re-invested & Datastream \\
\hline Market value & MV & $\begin{array}{l}\text { Share price multiplied by the number of ordinary shares in } \\
\text { issue }\end{array}$ & Datastream \\
\hline Market-to-book & MTBV & $\begin{array}{l}\text { Market value of the common equity divided by the balance } \\
\text { sheet value of the common equity }\end{array}$ & Datastream \\
\hline \multicolumn{4}{|c|}{ Panel C: Bond data } \\
\hline Clean price & $\mathrm{CP}$ & Price of an issue, less any accrued interest & Datastream \\
\hline Days to maturity & $\mathrm{LF}$ & Market default life of the security & Datastream \\
\hline Bond rating & ISPHRT & Standard \& Poor's historic bond rating & Datastream \\
\hline \multicolumn{4}{|c|}{ Panel D: $C D S$ data } \\
\hline CDS spread & $\mathrm{SM}$ & $\begin{array}{l}\text { This shows the mid rate spread between the entity and the } \\
\text { relevant benchmark curve. }\end{array}$ & Datastream \\
\hline Issuer rating & & $\begin{array}{l}\text { Moody's and if not available, Standard \& Poor's long-term } \\
\text { issuer rating }\end{array}$ & $\begin{array}{l}\text { Moody's/ } \\
\text { Standard \& Poor's }\end{array}$ \\
\hline \multicolumn{4}{|c|}{ Panel E: Systemic risk measures } \\
\hline$\Delta \mathrm{CoVaR}$ & & Own calculation. Source of market equity data: & Datastream \\
\hline MES & & Own calculation. Source of market equity data: & Datastream \\
\hline SRSIK & & Own calculation. Source of market equity data: & Datastream \\
\hline
\end{tabular}

